Florida International University FIU Digital Commons

6-12-2017

\title{
The Contribution of the Special Court for Sierra Leone to the Law on Criminal Responsibility of Children in International Criminal Law
}

Ana Paula Podcameni

Florida International University, apodcame@fiu.edu

DOI: $10.25148 /$ etd.FIDC001974

Follow this and additional works at: https://digitalcommons.fiu.edu/etd

Part of the Criminal Law Commons, Human Rights Law Commons, International Humanitarian Law Commons, International Law Commons, International Relations Commons, and the Jurisprudence Commons

\section{Recommended Citation}

Podcameni, Ana Paula, "The Contribution of the Special Court for Sierra Leone to the Law on Criminal Responsibility of Children in International Criminal Law" (2017). FIU Electronic Theses and Dissertations. 3358.

https://digitalcommons.fiu.edu/etd/3358 
FLORIDA INTERNATIONAL UNIVERSITY

Miami, Florida

THE CONTRIBUTION OF THE SPECIAL COURT FOR SIERRA LEONE TO THE LAW ON CRIMINAL RESPONSIBILITY OF CHILDREN IN INTERNATIONAL CRIMINAL LAW

A dissertation submitted in partial fulfillment of the requirements for the degree of DOCTOR OF PHILOSOPHY in INTERNATIONAL RELATIONS

by

Ana Paula von Bochkor Podcameni 
To: Dean John F. Stack, Jr.

Green School of International and Public Affairs

This dissertation, written by Ana Paula von Bochkor Podcameni, and entitled The Contribution of the Special Court for Sierra Leone to the Law on Criminal Responsibility of Children in International Criminal Law, having been approved in respect to style and intellectual content, is referred to you for judgment.

We have read this dissertation and recommend that it be approved.

Benjamin Smith

Markus Thiel

Susanne Zwingel

Harry Gould, Major Professor

Date of Defense: June 12, 2017

The dissertation of Ana Paula von Bochkor Podcameni is approved.

Dean John F. Stack, Jr. Green School of International and Public Affairs

Andrés G. Gil

Vice President for Research and Economic Development and Dean of the University Graduate School

Florida International University, 2017 
C Copyright 2017 by Ana Paula von Bochkor Podcameni All rights reserved. 


\section{DEDICATION}

To my dad, my academic and life role model. I love and miss you everyday. 


\section{ACKNOWLEDGMENTS}

First of all, this work could not have been possible without the financial support of CAPES and the US Fulbright Institute. Financial help also came from SIPA, where I was fortunate to receive a teaching assistantship until I concluded my program.

Among the people who were directly involved with the production of the present dissertation, the most important is my adviser, Dr. Harry Gould. Without his words of encouragement, his calm attitude, his vote of confidence and finally his valuable feedback (and text editing skills) I would not be here today. I am most grateful for being given the opportunity and the freedom to research and construct my work as I intended to.

The second most important person during this process was Dr. Nicholas Onuf, someone I had the delightful opportunity to meet many years before considering to purse a doctorate. Nick has been of the highest importance in my academic life, influencing me in every step, from the very start when I was still a master student in Rio de Janeiro to taking some time away from his busy life to read and re-organize my first dissertation draft. His words of encouragement were of the utmost importance. So, thank you, for your continuous care and support.

I would also like to thank the professors in my committee (Dr. Smith, Dr. Thiel, and Dr. Zwingel) not only for the inspiring classes but also for the valuable feedback I have received on this work. 
Dr. Jalloh, I am grateful for you meeting with me at the beginning of this research project, showing interest and encouraging me to do the work, even though the topic was a bit distant from my initial areas of expertise.

My appreciation is also extended to Dr. Moats, my teaching supervisor, for allowing me to continue to instruct International Law while writing this dissertation. The classes surely helped me deepen my studies on the topic.

Other professors, such as Dr. Washington have been supportive and have directly contributed to my enrichment, so thank you!

Also, thank you my friend and professor Dr. Roberto Yamato, who read and gave me valuable feedback when I was still taking my first steps into this research.

I would also like to acknowledge the importance of some of my peers, particularly, Dr. Charles Heck who has been an amazingly supportive friend, someone who has helped me anticipate and solve most of the difficulties in my Ph.D. journey. Also, Bibek Chand, thank you for always being a wonderful and loving friend.

Thank you for all the department secretaries, especially Maria Diaz, Maria Elena Gil and Martha Rodriguez for helping me in all my bureaucratic and logistical needs. You guys make the department great.

My gratitude is extended to my dear family: my mother, Vera Podcameni, and sister Gabriela Podcameni. Your support and love were always the most important.

And finally to the person who has been with me through good times and hard times, has filled me with devotion and not once doubted my ability, my husband, Gabriel Grilo. 


\author{
ABSTRACT OF THE DISSERTATION \\ THE CONTRIBUTION OF THE SPECIAL COURT FOR SIERRA LEONE TO THE \\ LAW ON CRIMINAL RESPONSIBILITY OF CHILDREN IN INTERNATIONAL \\ CRIMINAL LAW \\ by \\ Ana Paula von Bochkor Podcameni \\ Florida International University, 2017 \\ Miami, Florida \\ Professor Harry Gould, Major Professor
}

The revision of laws and the application of culpability to those most responsible for serious humanitarian law violations has functioned as a necessary condition for achieving peace in most post-war societies. However, there is an embarrassing silence when it comes to addressing the question of whether children are to be subjected to the principle of individual criminal responsibility. As morally controversial as it is, the question remains fundamental. Unfortunately, children have been involved in armed conflicts, as victims primarily, but not exclusively. Children are among those accused of having committed brutal and terrible international crimes in times of armed conflict when part of armed groups or armed forces. And with no consensus within the international community regarding their status within International Criminal Law — no established law within International Law and no consistent practice among states on the issue - the problem of criminal accountability of children accused of international crimes remains unanswered. 
The current work conducts a legal positivist analysis with the focus of investigating the contribution of the Special Court for Sierra Leone to the current debate on children's criminal responsibility under International Criminal Law. Among significant contributions, the Statute of the Special Court brought one interesting innovation to the debate on children's potential criminal responsibility. Juveniles starting at age fifteen would be considered viable for prosecution if among those most responsible for the Special Court, as established in Article 7.1. The above innovation translates into two essential contributions to the debate on children criminal responsibility for international crimes: first the Special Court was the first international court to elect a minimum age of criminal responsibility (MACR) at age fifteen to be operational within the scope of the court. Secondly, and equally important, the court reflected the position that children, after the stipulated MACR would be considered, at least a priori, viable subjects of the international criminal system. 


\section{TABLE OF CONTENTS}

CHAPTERS

PAGES

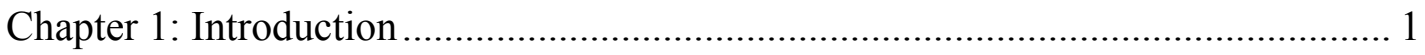

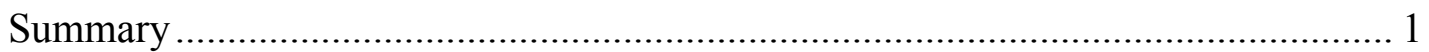

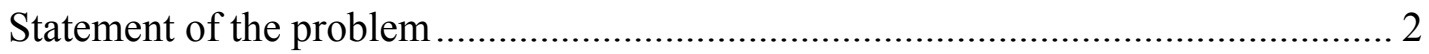

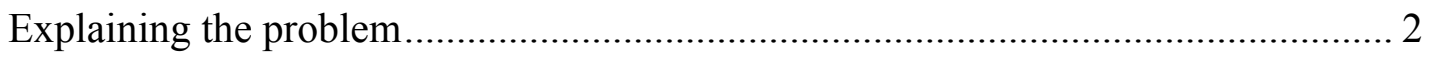

Ongwen's ICC trials: a possible glimpse of the court's position on the criminal

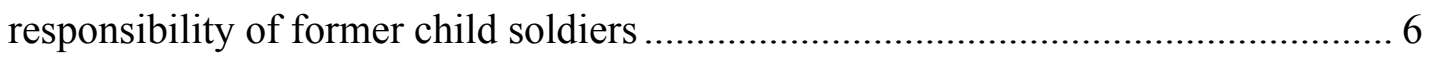

Numbers of active child soldiers. How many? Difficult to know .............................. 9

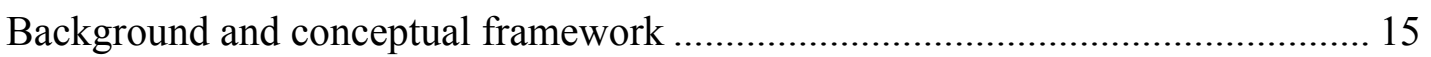

How does criminal law deal with the problem of child perpetrators? ...................... 18

How does international law deal with the problem of child soldiers?...................... 20

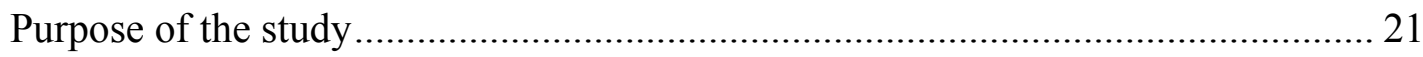

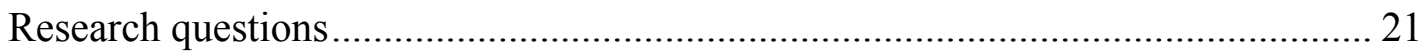

Definition of terms and some more theoretical framework .................................... 22

From moral responsibility to criminal responsibility............................................... 25

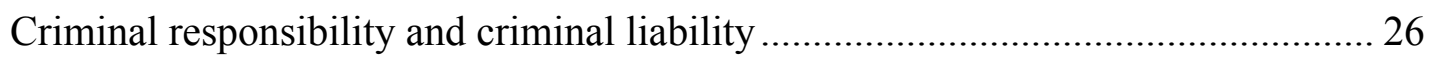

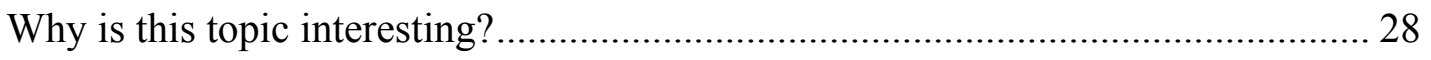

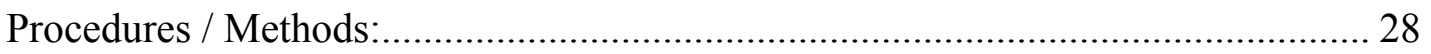

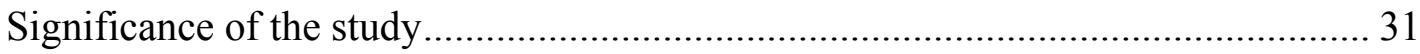

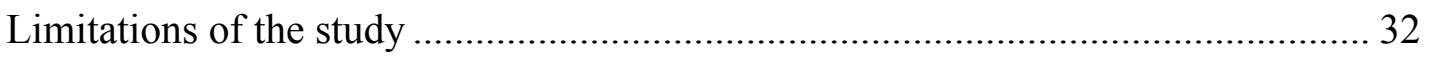

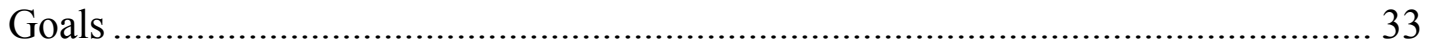

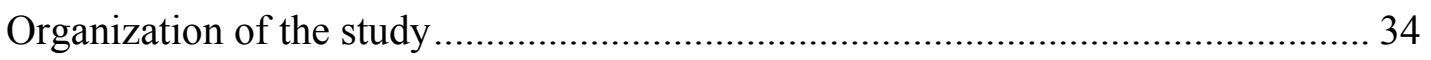

Chapter 2: Overview of how child soldiers are represented by UN officials,

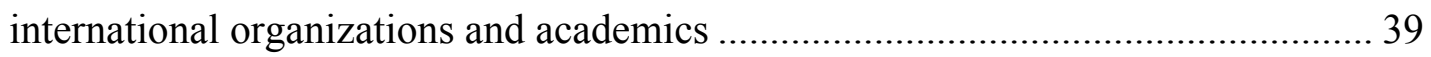

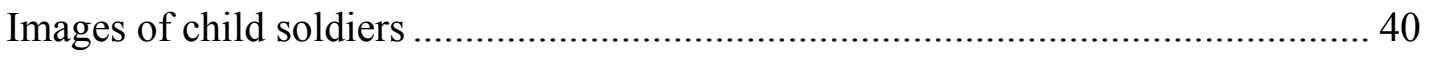

Child soldiers as described by international organizations...................................... 43

Common features of how international legal discourse describes child soldiers ..... 48

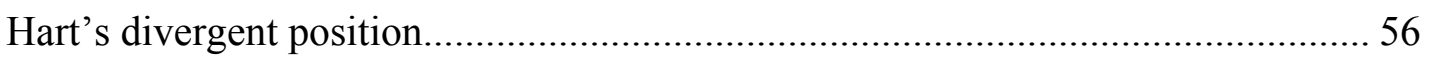

Chapter 3: Initial remarks and a note on methodology and the sources of

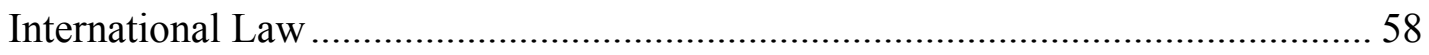

Why is it important to utilize a legal positivist approach when conducting

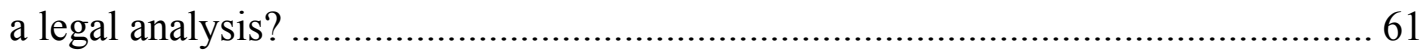

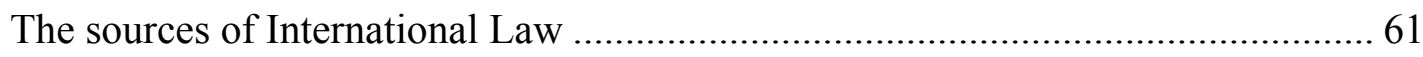

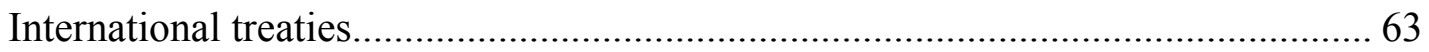

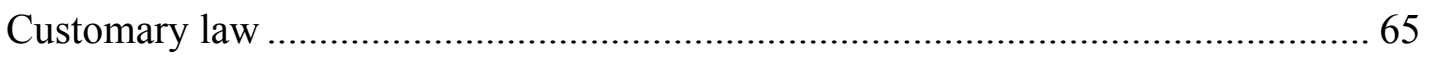

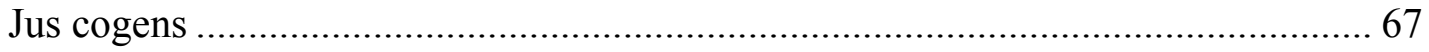




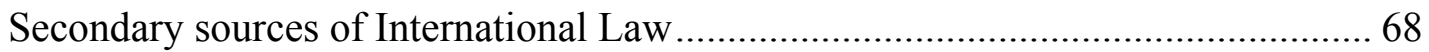

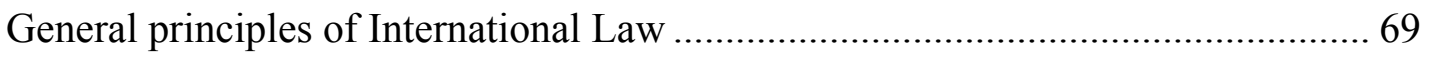

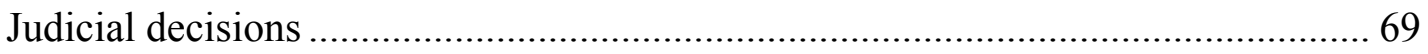

The writings of publicists and the teachings of the most highly qualified

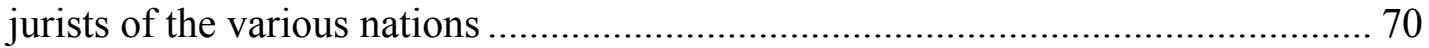

Chapter 4: Universal conceptions of childhood and the international regime of

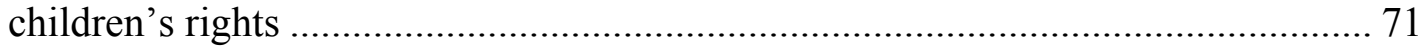

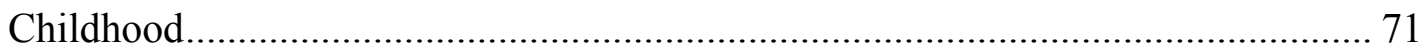

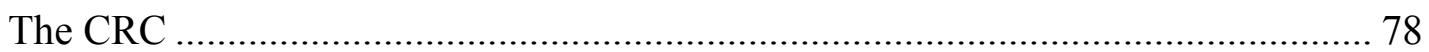

Chapter 5: Analysis of treaty and customary law on child recruitment and

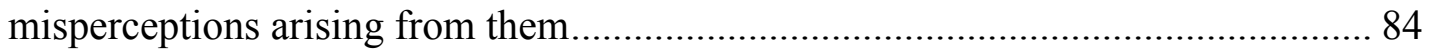

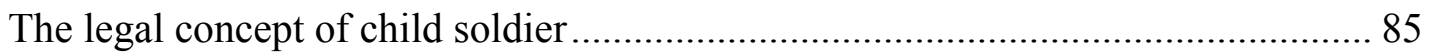

Definition of child soldier follows age criteria: fifteen or eighteen years old? ........ 87

How international law deals with the problem of child soldering ........................... 90

Legal protections against the recruitment and use of children in armed conflicts.... 90 When a child is engaged directly in the armed conflict does he or she loses the status of protected persons? How do International Humanitarian Law and International Human Rights Law treat an active child soldier?.... 100 An additional side note on misrepresentation of lex lata by the ICRC and the Office of the Special Representative of the Secretary-General for Children and Armed Conflicts 104

Chapter 6: How International Law currently deals with child soldiers: a

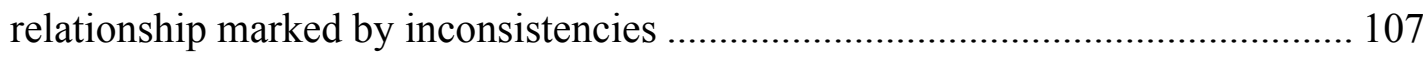

A discussion of the Minimum Age of Criminal Responsibility (MACR) ………... 107

Children before the UN ad hoc tribunals and the ICC........................................... 113

Criminal responsibility of child soldiers under current International Law ............. 114

Divergent positions: International law allows for the incrimination of children

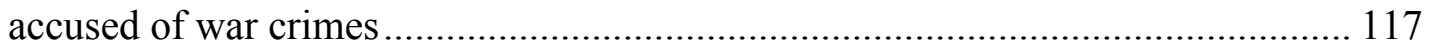

Chapter 7: International tribunals and the contribution of the SCSL to the emerging law on children's criminal responsibility in International

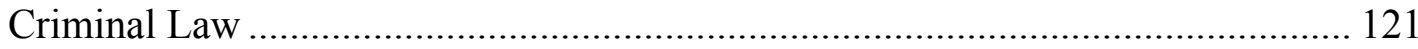

International criminal tribunals: an introduction ............................................... 122

Bringing the accused to justice: domestic courts and international courts ............. 128 Contributions of the international tribunals from post Second World War

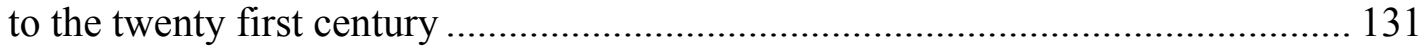

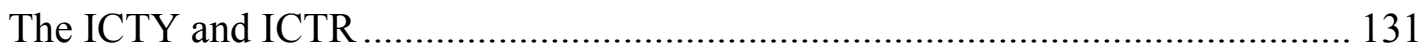

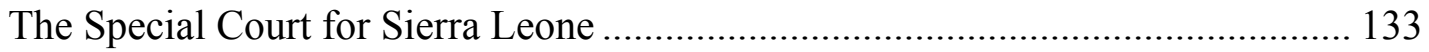

The International Criminal Court.......................................................................... 134 


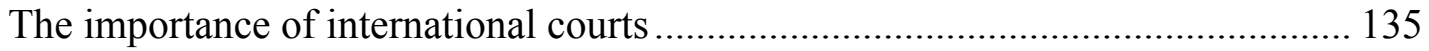

A deeper look at the Special Court for Sierra Leone .......................................... 136

How international criminal courts operate...................................................... 140

Sources of law of the international courts........................................................... 142

How important was the Special Court's decision to include minors as liable to individual criminal prosecution to the development of international criminal law?

Why fifteen was the chosen age by the UN Secretary General to act as the MACR in the Statute of the SCSL?....

Chapter 8: Final remarks on the presumed legal competence of children at the age of fifteen and over and individual criminal responsibility 156

Legal Personality in International Law .............................................................. 156

States as primary subjects and the place of the individual..................................... 158

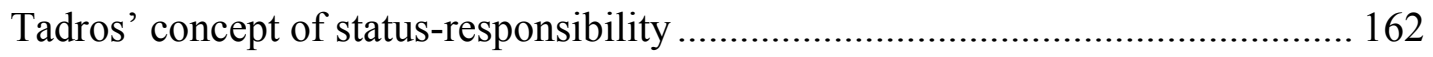

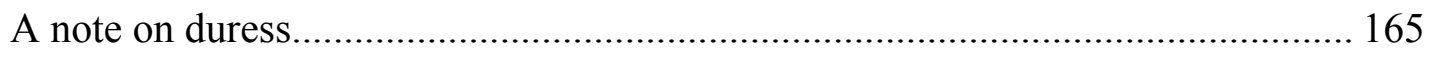

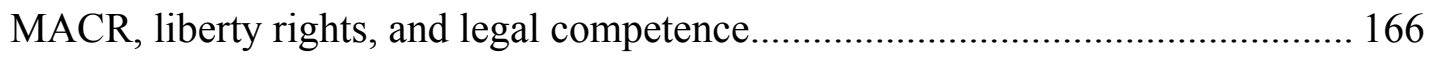

Legal competence and criminal responsibility ................................................ 169

The right to enlist as a liberty right that entails correlative individual

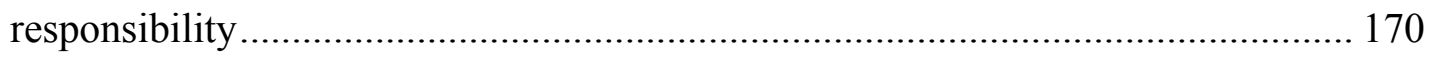

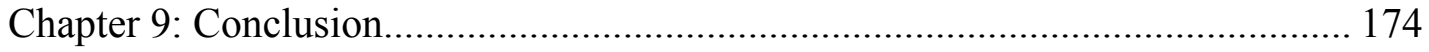

Recapitulation of purpose and findings / relationship with previous research ....... 174

Limitations of the research (anticipation of criticism)...................................... 175

Problems arising from the research.......................................................... 176

Implications of my findings/ contributions .................................................... 177

Recommendations (for research; for action/policy change) ............................. 177

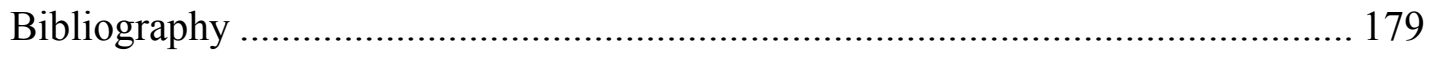

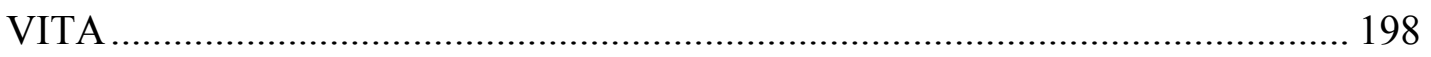




\section{ABBREVIATION AND ACRONYMS}

API

APII

CRC

CSI

DRC

GC

ICC

ICCPR

ICESCR

ICJ

ICL

ICRC

ICTR

ICTY

IHL

IHRL

IL

ILC

ILO

IMT
Additional Protocol to the Geneva Conventions I

Additional Protocol to the Geneva Conventions II

Convention on the Rights of the Child

Child Soldier International

Democratic Republic of Congo

Geneva Conventions

International Criminal Court

International Covenant on Civil and Political Rights

International Covenant on Economic, Social and Cultural Rights

International Court of Justice

International Criminal Law

International Committee of the Red Cross

International Criminal Court for Rwanda

International Criminal Court for former Yugoslavia

International Humanitarian Law

International Human Rights Law

International Law

International Law Commission

International Labor Organization

International Military Tribunal (set in Nuremberg) 


\begin{tabular}{|c|c|}
\hline IOs & International Organizations \\
\hline MACR & Minimum Age of Criminal Responsibility \\
\hline MALR & Minimum Age of Legal Recruitment \\
\hline NGOs & Non-Governmental Organizations \\
\hline OPAC & $\begin{array}{l}\text { Optional Protocol to the Convention on the Rights of the } \\
\text { Child on the Involvement of Children in Armed Conflict }\end{array}$ \\
\hline SCSL & Special Court for Sierra Leone \\
\hline TOKYO TRIBUNAL & International Military Tribunal for the Far East \\
\hline UK & United Kingdom \\
\hline UN & United Nations \\
\hline UN-IOs & United Nation's International Organizations \\
\hline UNDHR & United Nation's Declaration of Human Rights \\
\hline UNICEF & United Nations Children's Fund \\
\hline UNSC & United Nations Security Council \\
\hline UNSG & United Nations Secretary-General \\
\hline USA & United States of America \\
\hline VCLT & Vienna Convention on the Law of Treaties \\
\hline
\end{tabular}




\section{Chapter 1: Introduction}

\section{Summary}

The present research inquires into the controversial, yet unsettled, legal question of whether children are potentially subject to individual criminal responsibility under International Law (IL). As a first step, an analysis of the current state of law to the problem will be conducted, followed by a deeper look into the relevance of the works of the Special Court for Sierra Leone (SCSL) in determining a possible evolving rule of child criminality. The theoretical framework will be based on criminal law, international law and children's rights. The goal of the research is to show that the SCSL has generated evidence of law on the issue of children's potential prosecution which can be used by other international and non-international courts for future reference.

Are children involved in armed conflict and accused of the commission of war crimes to be subjected to the international legal rule of individual criminal responsibility?

The present research delineates a legal positivist analysis investigation of International Criminal Law's position on the controversial, necessary and unsettled issue of child criminal responsibility. To date, the problem has remained unanswered by international law.

The present analysis delineates a positivist legal investigation, therefore, primary sources of law are given precedence over secondary and non-binding documents. More specifically, I will be looking into treaty and customary law because these are binding sources of law.

Next, the work will focus on the jurisdictional contributions coming from the only court that has included juveniles as viable subjects of international criminal law: The 
Special Court for Sierra Leone. I intend to show the existence of legal precedent created by the Special Court that can be used by international courts or national courts on the issue of child criminal responsibility under international law.

The dissertation will conclude with suggestions for future research, in which the author will explore complementary venues sourced from the minimum age of legal recruitment as established by International Humanitarian Law, the minimum age of criminal responsibility as set by the SCSL, as well as the concomitant relationship between the liberty right of early enlistment, legal competence and individual criminal responsibility for children lawfully recruited by armed forces. Preliminary theoretical findings suggest that when legal competence is presumed, it fulfills a priori the criteria for the exercise of individual criminal responsibility.

\section{Statement of the problem}

The existing laws against child soldiers in International Law, more specifically, International Humanitarian Law, allows the recruitment and use of children by the armed forces of states starting at age fifteen; however, if the underage recruited is accused of international crimes while in the line of duty, International Law has no position on whether these children are criminally responsible for his or her acts.

\section{Explaining the problem}

The laws prohibiting states from recruiting and using children under the age of fifteen in armed conflicts are contained in the Protocol Additional to the Geneva Conventions of 12 August 1949, and relating to the Protection of Victims of 
International Armed Conflicts (Additional Protocol I) of 8 June 1977, more specifically Article 77, Protocol Additional to the Geneva Conventions of 12 August 1949, and relating to the Protection of Victims of Non-International Armed Conflicts (Protocol II), of 8 June 1977 (Additional Protocol II), specifically part 4 and Article 38 of the Convention of the Rights of the Child (CRC) of 1998 which are deemed to be customary law and are liable to be used as residual law by international courts. There are no prohibitions in customary International Humanitarian Law against states recruiting and using children age fifteen and above. The only rule in the above conventions protecting the young recruit is circumstantial, expressing that states, when recruiting and using those between age fifteen and seventeen, are to give priority enlistment to those who are older. These legal rules have achieved wide support within the international community, and are currently viewed as reflecting obligations extending to all states and individuals. The Optional Protocol to the Convention on the Rights of the Child on the involvement of children in armed conflict (OPAC) of 2002 is currently the only international human rights treaty prohibiting the recruitment and use of persons under eighteen, yet it has not been recognized as customary law, thus creating the obligation of compliance exclusively to its State parties.

Early enlistment is seen as problematic, mostly by academics and child specialists who call attention to the lack of maturity and de facto competence of a child below eighteen to enlist in such a dangerous and challenging task as taking arms. Despite the fact that it is important to acknowledge these rules may not reflect morally constituted opinions regarding children's capacities, the goal of the current work is not to challenge the current law related to early recruitment, but expose the fact that international 
humanitarian law allows it, thus deeming these young people legally competent to engage in combat training and hostilities.

Also equally problematic, if the child who has reached the minimum age of military recruitment (set at fifteen) by International Humanitarian Law, happens to be involved in the commission of a war crime (or any other international crime) international law does not hold a consensus position regarding whether he or she is to respond criminally for his or her act.

Despite the facts that all individuals are obligated to observe international humanitarian law, and that children under eighteen perpetrate serious violations of international humanitarian which would give rise to criminal accountability for an adult, there are no international legal provisions, documents, or previous rulings from competent international tribunals that specify if a child is subject to the principle of individual criminal responsibility under international criminal law if accused of a grave breach of international humanitarian law.

The drafters of the Rome Statute of the International Criminal Court intentionally excluded individuals who were under the age of eighteen at the time the act was committed from the Court's jurisdiction. ${ }^{1}$ No other international court has yet brought a juvenile to justice for violations of International Humanitarian Law. No domestic court has tried a juvenile for grave breaches of international humanitarian law. The turning point was the Statute of the SCSL which, for the first time, attributed criminal responsibility to those fifteen years of age or older.

\footnotetext{
${ }^{1}$ Schabas, William. The International Criminal Court: A Commentary on the Rome Statute, (Oxford: Oxford University Press, 2007), 72.
} 
Before then, jurisdiction over crimes committed by child soldiers was been exercised at the domestic level (and not at the international level) with three attempts to prosecute former child soldiers - two rulings in the Democratic Republic of Congo and one in Uganda. ${ }^{2}$ These children were brought to court charged with violations of domestic law, not international crimes. No courts, international or national, have ever tried child soldiers for violations of international law.

In International Law, children are mostly the victims of international crimes, even if they are the ones who committed them. ${ }^{3}$ When serious violations that amount to international crimes are carried out by children, the "responsibility passes entirely to the adult abductor, enlister, recruiter or commander." "The fact that children are capable of violence falls outside the entrenched modernist formulations of childhood" that consequently feeds into the development of legal rules. ${ }^{5}$ As a result, serious violations, which would amount to international crimes if committed by adults, do not receive the same legal treatment when perpetrated by children. This is problematic because, when it

\footnotetext{
${ }^{2}$ Happold, Matthew. "The Age of Criminal Responsibility for International Crimes Under International Law," From Peace to Justice Series International Criminal Accountability and Rights of Children, eds. Karin Arts and Vesselin Popovski (Hague Academic Press, 2006), 69-84.

${ }^{3}$ Mark Drumbl calls attention to how constructed images of child soldiers directly affect their legal treatment. Within the existing available discourse of child soldiers (produced mainly in the West), the overwhelming image of the child soldier as a faultless passive victim prevails. The child is seen as a victim of violent recruitment and training by their commanders. Facing such violence and hardships of the war children are helpless, and this innocence "fills the international legal imagination, influencing the substance of international law and policy" (Drumbl, Mark A., Reimagining Child Soldiers in International Law and Policy (Oxford: Oxford University Press, 2012), 9.

${ }^{4}$ Drumbl, Reimagining Child Soldiers in International Law and Policy, 18.

${ }^{5}$ Honwana, Alcinda . "Innocent and Guilty: Child-Soldiers as Interstitial and Tactical Agents," Makers \& breakers: children \& youth in postcolonial Africa, eds. Alcinda Honwana and Filip Boeck (Africa World Press, 2005), 31, 37.
} 
comes to international crimes, the nature and the seriousness of the crimes should not outweigh the conditions of the accused, and the victim still has the rights to justice.

And what if the armed group was commanded by children, and not adults? As strange as this may sound, the leaders of an armed rebel group, God's Army, composed of approximately 200 men, formed in 1997 to fight against the Burmese government, was led by twin brothers, age nine. The boys operated the armed group until 2001 (age 13) when they surrendered to the Thai government. ${ }^{6}$ In this case, when the leaders are/were minors, where does criminal responsibility of those who ordered the crimes stands?

Ongwen's ICC trials: a possible glimpse of the court's position on the criminal responsibility of former child soldiers

Dominic Ongwen's criminal case, currently taking place at the ICC, may force the Court to further elaborate its position whether former child soldiers are to be deemed criminally responsible under International Criminal Law. Despite the fact that the ICC has so far avoided discussion of the criminal responsibility involving acts committed by child soldiers by deliberately avoiding the question of whether children can be submitted to the principle of individual criminal responsibility when accused of international crimes. Article 26 of the Rome Statute entitled "Exclusion of jurisdiction over persons under eighteen" expresses clearly that the "The Court shall have no jurisdiction over any person who was under the age of 18 at the time of the alleged commission of a crime."

\footnotetext{
${ }^{6}$ For more information, see: "Two little boys," The Guardian, (London) July 07, 2000, https://www.theguardian.com/g2/story/0,3604,347432,00.html.
} 
The trial of Ongwen, however, has touched on the matter by asking whether a former child soldier, raised in an armed group, is to be held responsible for his criminal acts? Ongwen's case is interesting and important because "[Ongwen] is the first former child soldier to face trial at the institution, and the first defendant to be both alleged perpetrator and victim of the same crimes." ${ }^{, 7}$ Ongwen's case, despite not directly addressing the issue of criminal acts committed by children (Ongwen is an adult at the time of the judgement), nonetheless highlights the necessity for the Court to discuss if and how much coercive conditions and young age affect criminal responsibility.

Ongwen's story starts similarly to the stories of many child soldiers in Uganda; he was abducted by the LRA at the age of ten, and forced to endure brutal training and violence. Ongwen learned and suffered the violent life of a child soldier, yet as the years passed, he was raised to more prominent positions within the group, and later, as a commander, was in charge of ordering and committing human atrocities.

Ongwen is now facing criminal charges for all 70 counts brought by the prosecution:

The alleged crimes were purportedly committed against internally displaced persons in northern Uganda between 2002 and 2004. They include attack against the civilian population, murder and attempted murder, rape, sexual slavery, torture, cruel treatment, and outrages upon personal dignity. Others are enslavement, forced marriage as an inhumane act, persecution, destruction of property, pillaging, and the conscription

\footnotetext{
7 “Trial of ex-child soldier Dominic Ongwen to hear prosecution case," The Guardian, January 16, 2017, https://www.theguardian.com/law/2017/jan/16/trial-ex-child-soldier-dominic-ongwen-to-hear-prosecutioncase-icc-uganda.
} 
and use of children under the age of 15 to participate actively in hostilities. ${ }^{8}$

Most of the charges against Ongwen focus on attacks on refugee camps between 2002 and 2005 in northeastern Congo in December 2009, in which about 350 civilians were killed and another 250 , including at least 80 children, were abducted. ${ }^{9}$

The defense has concentrated on the fact that Ongwen was brutalized and traumatized after being abducted: "He was tortured ... forced to watch people being killed, used for fighting as a child soldier" ... Such conditions would at least serve as "a serious mitigating factor," explained Thomas Obhof, a US lawyer based in Uganda and part of the defense team. ${ }^{10}$

So, the central question for the court to decide, as framed by the defense team is how much the experience of being an abducted and brutalized as a child and made into a soldier unwillingly mitigates (if it does mitigate) the individual criminal responsibility of the adult he became? That is the discussion brought forth by the present case. It will be the first time that the ICC will hopefully be discussing and position itself regarding the criminal responsibility of someone that is considered a perpetrator, yet was made a victim by the same organization.

\footnotetext{
${ }^{8}$ Wairagala Wakabi, “Ongwen Trial to Open in December but Defense Cites Challenges”, International Justice Monitor, LRA Trials (May 31, 2016), https://www.ijmonitor.org/2016/05/ongwen-trial-to-open-indecember-but-defense-cites-challenges/).

9 “Trial of ex-child soldier Dominic Ongwen to hear prosecution case,” The Guardian (January 16, 2017).

10 “Trial of ex-child soldier Dominic Ongwen to hear prosecution case," The Guardian (January 16, 2017).
} 
The trial is ongoing, with the prosecution currently making submissions, and it only a matter a time before the final adjudications are out, and hopefully the ICC will provide an indication of where it stands in relation to cases of criminal accountability of former child soldiers. ${ }^{11}$

\section{Numbers of active child soldiers. How many? Difficult to know}

'Any person under eighteen years of age who is part of any kind of regular or irregular armed force or armed group in any capacity' is to be considered a child soldier according to the Cape Town Principles and Best Practices of 1997. As of 2007, the Paris Principles have instead suggested a new term which would theoretically include a wider protection for children involved in armed conflict, and this was labeled: 'children associated with armed forces and armed groups.' Nonetheless, the academic literature and jurists alike have continued to treated children involved in armed conflicts using the nomenclature of child soldiers, as it will be done in the present work.

According to the Coalition to Stop the Use of Child Soldiers, child soldiers have been used in most armed conflicts and almost every region of the world; "tens of thousands of children under the age of eighteen continue to serve in government forces or armed opposition groups. Some of those involved in armed conflict are under ten years old." ${ }^{12}$ Despite international organizations' worldwide advocacy toward putting an end to

\footnotetext{
${ }^{11}$ Lino Owor Ogora,"'To Punish or to Pardon? Perspectives on Accountability and Forgiveness in the Case of Dominic Ongwen, International Justice Monitor, LRA Trials, March 30, 2017, https://www.ijmonitor.org/2017/03/to-punish-or-to-pardon-perspectives-on-accountability-and-forgivenessin-the-case-of-dominic-ongwen/.

${ }^{12}$ Child Soldiers International, an independent human rights organization previously associated with a coalition of leading human rights and humanitarian organizations, Amnesty International; Defense for Children International; Human Rights Watch; International Federation Terre des Hommes; International Save the Children Alliance; Jesuit Refugee Service; the Quaker United Nations Office-Geneva; and
} 
the recruitment and use of child soldiers, the number of governments employing children has not decreased since 2004 (from ten situations of 2003 to nine situation of 2004 in which governments used children). ${ }^{13}$

Child Soldiers International has declared:

Since January 2011, eighteen states were reported to have used girls or boys in hostilities. In some cases, children were deployed as members of official state armed forces including, national armies, paramilitaries, civil defense, police and other forces established by law (Afghanistan, Côte d'Ivoire, Democratic Republic of the Congo/DRC, Iraq, Libya, Myanmar, Philippines, Somalia, Sudan, South Sudan, Thailand and Yemen). In others they were part of state-allied armed groups such as irregular paramilitaries and "self-defense" groups which were backed by, or allied to, government forces but were not officially part of them (Central African Republic, Côte d'Ivoire, Somalia, Sudan and Yemen). ${ }^{14}$

World Vision International. http://www.child-soldiers.org/our history.php and "About the issue" and "Frequent Asked Questions": At Child Soldier International: http://www.childsoldiers.org/about_the_issues.php; http://www.child-soldiers.org/faq.php.

13 “Summary", Child Soldier Global Report, https://www.child-soldiers.org/shop/global-report-2008-1 (United Kingdom, 2008).

${ }^{14}$ According to Child Soldiers International:

There are, some states which, contrary to best practice, still permit the voluntary recruitment of under-eighteens. According to the latest available information seventeen year olds can enlist in the armed forces of Algeria, Australia, Austria, Azerbaijan, Bolivia, Brunei, Cape Verde, Chile, China, Cuba, Cyprus, France, Germany, Israel, Jamaica, Lebanon, Malaysia, Malta, Netherlands, New Zealand, the Philippines, Sao Tome and Principe, Saudi Arabia, and the USA continue to permit the voluntary recruitment at the lower age of sixteen years are: Bangladesh, Brazil, Canada, Egypt, El Salvador, India, Iran, Ireland, Jordan, Mauritania, Mexico, Pakistan (with exception of aero-technicians), Papua New Guinea, Singapore, Tonga, Trinidad and Tobago, the United Kingdom, and Zambia. In a few states, there is no minimum age, or it has been set below sixteen years. Such states include Barbados, Guinea-Bissau, Guyana, Pakistan (aero-technicians only), and the Seychelles.

("Frequent Answers, and Questions", Child Soldier International, http://child-soldiers.org/faq.php and http://www.child-soldiers.org/theme reader.php?id=1). 
The recruitment of young soldiers is not an approach exclusively perpetuated by developing countries; developed countries such as the United Kingdom and the United States enlist children (individuals under the age of eighteen) in their military forces. ${ }^{15}$

Whether forced into service or simply by volunteering to join, it is indisputable that children become part of armed forces and armed groups. UNICEF's data states that around 300,000 children-boys and girls under the age of eighteen-are today involved in more than 30 conflicts worldwide. ${ }^{16}$

Rachel Brett and Margaret McCallin in 1966 called child soldiers 'invisible soldiers. ${ }^{17}$ They are the unseen soldiers; with no precise number of how many child soldiers are currently engaged in armed conflicts. There are also no numbers of former child combatants. One of the reasons being non-state armed groups, which are the largest recruiters of child soldiers, work mostly illegally, with no concern for accountability, making it impractical to know how many child soldiers they recruit. Also, it is very common for armed groups and armed forces to deny the presence of child soldiers, in an attempt to avoid moral and legal consequences:

\footnotetext{
${ }^{15}$ In an article published by The Independent regarding the British army, in 2014. “....more than one in 10 new Army recruits are boy soldiers of just 16 years old, according to the latest figures released by the Ministry of Defense. And more than one in four of all new Army recruits is under 18 - too young to be sent into combat. "UK under fire for recruiting an 'army of children", http://www.independent.co.uk/news/uk/home-news/uk-under-fire-for-recruiting-an-army-of-children9431966.html (May 24, 2014).
}

The US also recruits under age soldiers as shown in Sherwood, Ross, "America's Child Soldiers: US Military Recruiting Children to Serve in the Armed Forces," http://www.globalresearch.ca/america-s-childsoldiers-us-military-recruiting-children-to-serve-in-the-armed-forces/11210 (November 29, 2008).

16 "Fact Sheet: Child Soldiers", UNICEF, http://www.unicef.org/emergencies/files/childsoldiers.pdf. Accessed on November 201

${ }^{17}$ Rachel, Brett, and Margareth McCallin, Children: The Invisible Soldiers. Ed. Radda Barnen (Stockholm: Save the Children, 1998). 
the presence of children in military ranks is not officially acknowledged in fact, is often denied - no measures are taken to prevent their

deployment. As a result, children are used extensively in hostilities both in combat and non-combat roles by national armies of DRC, Myanmar, Sudan and Yemen...In some countries, 'age blindness' can also be the product of not knowing. In Uganda and the Philippines, for example, low rates of birth registration result in the likelihood that children are present among voluntary recruits. ${ }^{18}$

Brett and McCallin have acknowledged "there is a wide variation in the estimates of the number of child soldiers involved. The total number of child soldiers in each country, let alone the global figure, is not only unknown but unknowable. The figures presented in their book functions as a 'best guess' as of May 1998."19

Most of the websites and publications concerning child soldiers borrowed their numbers from Graça Machel' report “Impact of Armed Conflict on Children” requested by the UN Secretary-General and submitted under General Assembly resolution 48/157 of 1996. In her report, she initially indicated that: "an estimated 300,000 children under 18 are participating in conflicts -- fighting on the front lines, abused as sex slaves or used for portering. ${ }^{20}$ However, oddly, this estimation is no longer present in her original report. As it seems the original passage was substituted by: “...over the past 30 years,

\footnotetext{
18 "Report Louder than Words: An agenda for action to end State Use of Child Soldiers." Child Soldier International, https://www.child-soldiers.org/shop/louder-than-words-1 (United Kingdom, 2012), 24.

${ }^{18}$ Kassier, Glenn. "The zombie claim that 300,000 children are used as child soldiers, The Washington Post (January 22, 2016) https://www.washingtonpost.com/news/fact-checker/wp/2016/01/22/the-zombie-claimthat-300000-children-are-used-as-child-soldiers/).

${ }^{19}$ Kassier, Glenn. "The zombie claim that 300,000 children are used as child soldiers, The Washington Post (January 22, 2016) https://www.washingtonpost.com/news/fact-checker/wp/2016/01/22/the-zombie-claimthat-300000-children-are-used-as-child-soldiers/).

${ }^{20}$ UNICEF, Press Release Graça Machel calls for an end to impunity for war crimes against children and women http://www.unicef.org/newsline/00pr64.htm.
} 
government or rebel armies around the world have recruited tens of thousands of

children. Most are adolescents, though many child soldiers are ten years of age..."21

In conclusion: “...providing authoritative figures for the number of child soldiers

worldwide today is nearly impossible - all numbers we quote are estimates, and even

estimates are not available for all situations of conflict," said Nick Scarborough,

administrative officer of Child Soldiers International. ${ }^{22}$

With regard to young soldiers recruited by armed forces:

a survey conducted by Brett and McCallin's (1998) shows that while most state practice tends towards establishing recruitment policies starting at age eighteen, a substantial minority (thirty-four, about a third of the total surveyed) still recruited from the ages of fifteen, sixteen or seventeen. This second group includes some states with significant regional or global military capacities (Germany, Indonesia, Israel, South Africa, the UK, the USA, and Yugoslavia) and contains representatives of all regions of the world and the developing and developed states. ${ }^{23}$

More recent data collected by Child Soldier International shows that in the decade

between 1998 and 2008: "there was evidence that at least 25 states had used children in

\footnotetext{
${ }^{21}$ Kassier, The Washington Post, 2016: "Melanie Sharpe, a UNICEF spokeswoman told the Washing Post that 'the 300,000 figure is the only estimate of child soldiers globally, but it is indeed a timeworn stat, and we encourage colleagues and partners not to use it.' Sharp reported that the 300,000-figure first appeared in "The Impact of War on Children" by Graca Machel, published in 2001. (https://www.washingtonpost.com/news/fact-checker/wp/2016/01/22/the-zombie-claim-that-300000children-are-used-as-child-soldiers/) The book states that "current estimates put the number of child soldiers at about 300,000 at any one time." But when we examined Machel's footnotes, it turned out that she had relied on another source - the second (1998) edition of a 1996 book titled "Children: The Invisible Soldiers," by Rachel Brett and Margaret McCallin. So already, one can see that the 300,000number circulating in 2016 as a current fact was based on an estimate first published almost 20 years ago. (https://www.washingtonpost.com/news/fact-checker/wp/2016/01/22/the-zombie-claim-that-300000children-are-used-as-child-soldiers/.

${ }^{22}$ Kassier, Glenn. "The zombie claim that 300,000 children are used as child soldiers. The Washington Post January 22, 2016 (https://www.washingtonpost.com/news/fact-checker/wp/2016/01/22/the-zombie-claimthat-300000-children-are-used-as-child-soldiers/).

${ }^{23}$ Happold, Matthew. "Child Soldiers in International Law: The Legal Regulations of Children's Participation in Hostilities," in Netherlands International Law Review 1, no. XLVII (2000), 45 http://sro.sussex.ac.uk/id/eprint/26771.
} 
armed conflict as part of national armies. The figure for the first half of 2012 was less than ten." "In a few cases, an end to or reduced incidence of use of child soldiers by national armies is directly attributable to specific protection measures taken by states. However, in the majority of cases, the use of child soldiers has ceased simply because hostilities have ended. ${ }^{25}$

Some states also continue to deploy child soldiers as confirmed by the Child Soldier International report "Louder Than Words":

ten States deployed under-18s in hostilities as part of national armies (army, navy, air force), between January 2010 and June 2012 (Chad, Côte d'Ivoire, the Democratic Republic of the Congo, Libya, Myanmar, Somalia, South Sudan, Sudan, United Kingdom and Yemen). But when the wider spectrum of forces for which states are responsible are included (other official elements of state armed forces and state-allied armed groups) a total of seventeen states are found to have used child soldiers in this period (the above, plus Afghanistan, Central African Republic, Eritrea, Iraq, the Philippines, Rwanda and Thailand). In another three States: Colombia, Israel and Syria children were not formally recruited but were nevertheless reported to have been used for military purposes including intelligence gathering and as human shields. ${ }^{26}$

Even when legal measures are in place to avoid the recruiting and deploying of children under eighteen, in times of war, states can still make use of younger soldiers by justifying the engagement as military necessity. As a result, if a state allows the recruitment of young soldiers, there is no guarantee that it will cease using them if it needs them.

\footnotetext{
${ }^{24}$ Child Soldiers International, "Louder than Words," (2012), 17.

${ }^{25}$ Child Soldiers International, "Louder than Words," (2012), 17.

${ }^{26}$ Child Soldiers International, "Louder than Words," (2012), 11.
} 


\section{Background and conceptual framework}

In International Law, the term 'responsibility' traditionally referred (and still mostly does) to a 'State responsibility,' that is when a State is in violation of its legal obligations, thus needing to provide compensation to any other State injured by its violations. The doctrine of State responsibility evolved through custom and had been codified by the International Law Commission. The Draft Articles on Responsibility of States for Internationally Wrongful Acts was adopted by the UN General Assembly in 2001.

Until the end of the Second World War, the term 'international responsibility' was used almost exclusively to state's violations of its international obligations. Afterwards, the term found new connotations under the workings of the International Military Tribunals of Nuremberg and the International Military Tribunal for the Far East. At these Tribunals, men were brought to trial and charged individually for their alleged violations of international law. Individual criminal responsibility, previously applied in limited cases of piracy and slave trading, was henceforth attributed to war crimes and the new category of crimes against humanity.

As a result, and since the end of the Second World War, states have been authorized (and sometimes required) either to prosecute and punish or to extradite an individual accused of having committed serious international crimes. ${ }^{27}$

According to international law, individuals unlike states, are subject to being accused of international crimes. ${ }^{28}$ International crimes are understood as acts that violate

\footnotetext{
${ }^{27}$ Cassese, International Criminal Law (Oxford: Oxford University Press 2008), 3.
} 
essential values shared by the international community as a whole. When breaches of this kind occur, each state shares the responsibility of bringing the accused to justice. ${ }^{29}$ In other words, international crimes are subject to universal jurisdiction; this means basically that any country - irrespective of whether it has a direct jurisdictional link to the crimes - can bring the accused to trial. states are obligated to not obstruct justice for the accused; therefore they should either "try or extradite" the accused so he or she can be brought to justice in another State. This is because international crimes are understood to affect the society of states as a whole, therefore allowing states to prosecute the accusers independent of the existence of links of nationality or territoriality.

\footnotetext{
${ }^{28}$ In the final draft of the Articles on Responsibility of States for Internationally Wrongful Acts, Article 19 entitled "International Crimes and International Delicts", which contemplated imposing criminal responsibility upon states for serious breaches of IL and international crimes was deleted.

${ }^{29}$ According to Cassese (2008): "International crimes are breaches of international rules entailing the personal criminality of the individuals concerned (as opposed to the responsibility of the state of which the individual may act as organs). As according to Cassese 2008, International crimes result from the cumulative presence of the following elements:
}

1. Violation of customary international rules

2. Violation of rules intended to protect values considered important by the whole international community and thus binding to all states and individuals.

3. There exists a universal interest in repressing these crimes...Under international law, their alleged authors may in principle be prosecuted and punished by any state regardless on any territorial or nationality link with the perpetrator or the victim.

4. If the perpetrator has acted in official capacity (de jure or de facto state official) [and is not head of state, foreign minister, or diplomatic agent or still serving--because they enjoy complete personal immunity], the state on whose behalf is barred from claiming enjoyment of the immunity from the civil or criminal jurisdiction of foreign states accruing under customary law. (Cassese, International Criminal Law, 2008, $11)$. 
The central assumption inaugurated by these two tribunals and later serving as the main foundation of the newly established International Criminal Law is that individuals who seriously violate International Humanitarian Law by committing international crimes are to be submitted to the principles of individual criminal responsibility under the International Law.

Currently, the principle of individual criminal responsibility stands at the center of the international criminal legal system: it is to be enforceable at the national and international level, and it has received the status of customary law, making it mandatory for all states to observe. ${ }^{30}$ It is regarded as an indisputable advance towards achieving international justice, and a significant change from the traditional understanding of international responsibility in which states almost exclusively were the ones obligate to provide reparation in cases of non-compliance with an international rule that caused injury to another party. ${ }^{31}$

Therefore, International Criminal Law deals with the liability of individuals, irrespective of who they are: “...the status of the perpetrator is irrelevant, except the crime of aggression." ${ }^{32}$ Even "if the perpetrator has acted in official capacity (de jure or de facto state official) the state on whose behalf he has performed the prohibited act is

\footnotetext{
${ }^{30}$ ICRC,“Customary IHL Handbook: Rule 102. Individual Criminal Responsibility,” https://ihldatabases.icrc.org/customary-ihl/eng/docs/v1_rul_rule102.

${ }^{31}$ International Center for Transitional Justice, "The investigation and prosecution of international crime is a fundamental component of transitional justice," https://www.ictj.org/our-work/transitional-justiceissues/criminal-justice. Last day accessed: March 22, 2017.

${ }^{32}$ Cryer, R at al, An Introduction to International Criminal Law and Procedure (Cambridge: Cambridge University Press, 2007), 5.
} 
barred from claiming enjoyment of the immunity from the civil or criminal jurisdiction of foreign states accruing under customary law..." 33

There is no pre-established list of international crimes over which international courts exercise jurisdiction. Each international court has the authority to determine its jurisdictional limits subject to its constitutive instrument. The most widely accepted list of international crimes subject to universal jurisdiction is that found in the Rome Statute, and these are the crime of genocide; crimes against humanity; war crimes; the crime of aggression. ${ }^{34}$

How does criminal law deal with the problem of child perpetrators?

In domestic law, children are recognized and treated as capable of responding to their acts, at least criminal acts, after reaching a certain stipulated age at which he or she is deemed legally competent to understand what he or she has done (this is the age of legal competence in criminal law, or the minimum age of criminal responsibility). A person who has attained the minimum age of criminal responsibility (MACR) is considered to, at least, a priori to understand his/her act and be legally capable of being held criminally accountable/responsible.

In most systems of criminal law, in addition to the criteria of status, for a person to be held criminally liable, the behavior of the accused needs to meet two requirements: a wrongful act (actus reus) and a guilty mind (mens rea). These two requirements constitute the very concept of a "crime." For one to "...be guilty of a crime, particularly

\footnotetext{
${ }^{33}$ Cassese, International Criminal Law, 12.

${ }^{34}$ Article 5 of the Rome Statute of the International Criminal Court.
} 
about serious offenses, it is not enough simply to have done a particular prohibited act; there must also be the element of a guilty mind.“35 If the element of mens rea is absent, the person may be excused from criminal responsibility. ${ }^{36}$ Mens rea, then is the subjective criterion for a crime, and consists in the accused having acted with harmful intention, knowledge or recklessness as to every element of the offense. ${ }^{37}$

Determining mens rea is one of the most challenging parts of the criminal justice process mainly due to the fact that it is impossible to backtrack to the moment of the act, get into the accused's head, and proof harmful intention. All attributions of intention are extrapolated from the accused's and only done a posteriori, of course.

As in national law, in International Criminal Law a culpable state of mind is normally proved in court by circumstantial evidence. In other words, one may infer from the facts of the case whether or not the accused, when acting in a certain way, willed or was aware, that his conduct would bring about certain result... This is the position taken by national and international courts. $^{38}$

In most national criminal systems the lack of mens rea is mainly presumed (defense of infancy) in younger children below the age of criminal responsibility. ${ }^{39}$ However, if the accused is an older child who has reached the age of criminal responsibility, he or she may be considered legally competent to be brought to trial. The trial can take place in a juvenile chamber, or depending on the age of the accused and the seriousness of the crime, the child can face the adult penal system. It is the prosecution's

\footnotetext{
${ }^{35}$ Happold, "The Age of Criminal Responsibility for International Crimes Under International Law," (2006), 2.

${ }^{36}$ Happold, "The Age of Criminal Responsibility for International Crimes Under International Law," 2.

${ }^{37}$ Duff, Anthony. "Legal and Moral Responsibility.” Philosophy Compass 4.6 (2009), 978.

${ }^{38}$ Cassese, International Criminal Law, 74.

${ }^{39}$ Happold, "The Age of Criminal Responsibility for International Crimes Under International Law," 2.
} 
duty to "to establish by evidence or informed admission that the child defendant had sufficient understanding of the nature of the offense." ${ }^{40}$ So, determining whether a child meets the requirement of mens rea, besides being paramount, is widely case-specific (context-dependent and better set on a case-by-case basis).

The goal here is not to extend the discussion to the viable ways the justice system identifies and proves intentional harm, knowledge, or recklessness in a particular crime, but to assert that in all of these cases, it should be established first and foremost that the accused exercised legal capacity, that he or she was able to understand the act performed, and could foresee the possible harmful outcomes.

How does international law deal with the problem of child soldiers?

International law deal with the problem of child soldiers by utilizing two fronts: prohibiting states from recruiting and using children under fifteen years of age (these obligations found in International Humanitarian Law and International Human Rights Law are set on states), and by bringing to justice those adult individuals directly involved in conscripting or enlisting children under fifteen to participate in hostilities. The adult recruiter is also responsible "...with respect to the acts perpetrated by the child soldier him/herself. ${ }^{, 41}$ Both of these positions are present in rules of International Humanitarian Law, International Human Rights Law, and International Criminal Law.

\footnotetext{
${ }^{40}$ Bennion, Francis. "Mens rea and defendants below the age of discretion." Criminal Law Review (2009), 757.

${ }^{41}$ Freeland, Joseph. "How International Law Deals with Child Soldiers," in ALTA Law Research Series, (2010), 3, http://www.austlii.edu.au/au/journals/ALRS/2010/10.html.
} 
Since no child accused of serious violation of International Humanitarian and Human Rights law has been brought before an international court or national court, it is at first glance - uncertain whether children are deemed legally subject to the international criminal system.

Purpose of the study

This dissertation will focus on the contributions of the Special Court for Sierra Leone in generating evidence of law on the issue of children's criminal responsibility for serious breaches of International Humanitarian Law and International Human Rights Law. The emphasis on the Special Court serves to answer, at least partially, the more general question of children's individual criminal responsibility in International Criminal Law.

Research questions

1- What is International Criminal Law's position on children accused of international crimes? Can children old enough to be legally recruited be considered old enough to be held criminally responsible? Are children deemed subjects of the international criminal system?

2- How important to the development of International Criminal Law was the Special Court's decision to include children under eighteen years old as potentially liable for criminal prosecution? 


\section{Definition of terms and some more theoretical framework}

'Children' will be considered 'anyone below the age of eighteen, unless previously granted majority by domestic law treated' as defined by Article 1 of the Convention on the Rights of the Child.

'Child soldiers' for the current work is understood as defined by the 2007 Paris Principles as 'any person below 18 years of age who is or who has been recruited or used by an armed force or armed group in any capacity, including but not limited to children, boys and girls used as fighters, cooks, porters, messengers, spies, or for sexual purposes. It does not only refer to a child who is taking or has taken a direct part in hostilities' (Principle 2.1).

The terms related to engagement with military services are borrowed from the Report, Louder than Words (2012), published by Child Soldier International in which: 'Recruitment': Refers to the means by which people become (formally or informally) members of armed forces or armed groups; 'Enlistment or voluntary recruitment' occurs when persons facing no threat or penalty join armed forces or groups of their own free will; 'Conscription' is compulsory recruitment into armed forces; 'Forced recruitment' is a form of forced labor: it takes place without the consent of the person joining the armed forces or armed groups. It is achieved mainly through coercion, abduction or under threat of penalty; 'Unlawful Recruitment" refers to the recruitment of children under the age stipulated by international treaties applicable to the armed forces or armed groups. ${ }^{42}$

\footnotetext{
42 "Louder than Words" (2012), 8-9.
} 
Responsibility in criminal law and for the purpose of this work will be treated as conceptualized by Duff (2007) as answerability. To be responsible is to be answerable; "answerable to a person or body who has the right or standing to call me to account; and I am thus answerable in virtue of some normatively laden description, typically a description of a role, that I satisfy."

Responsibility, then, is invoked when someone has acted or failed to act in a matter that was consistent with a certain set of rules, and thus was expected to behave in such a way as to not cause some form of harm to somebody. "When we hold an agent accountable for his actions, we do not merely demand an explanation for his actions. The agent's explanations make sense only because we think that there are norms that apply to the agent." ${ }^{44}$

The concept of accountability/responsibility is coupled with the idea that the act committed has caused some form of physical or/and moral damage to another person or institutions that can hold or request the doer to be held accountable. Accountability initially involves that the person assumes some form of reparation of the damage done.

It is a commonplace that responsibility involves a dyadic relationship: an agent is responsible for something. The relational conception of responsibility that concerns us here is not merely dyadic, but triadic: I am responsible for $\mathrm{X}$, to $\mathrm{S}$ - a person or body who has the standing to call me to answer for X... ${ }^{45}$

\footnotetext{
${ }^{43}$ Duff, Antony, Answering for Crime: Responsibility and Liability in the Criminal Law, (Oxford: Hart 2007), 23.

${ }^{44}$ Tadros, Victor, Criminal Responsibility (Oxford: Oxford University Press, 2005), 29.

${ }^{45}$ Duff, Answering for Crime: Responsibility and Liability in the Criminal Law (2007), 23.
} 
Action is the main basis for attributing responsibility. When we hold a person responsible, we hold them responsible for some act, which can ironically include failing to act when it was expected thus generating some form of damage to another party.

Because "responsibility is fundamentally connected to answerability," the person who performed the act is indeed requested to provide an answer/provide a justification for his actions, and if no suitable justification/explanation is provided, then he or she who suffered the from the act may wish to file some claim against the perpetrator. ${ }^{46}$ If an acceptable justification is given, then the perpetrator may have his or her responsibility demised or waived completely. ${ }^{47}$

According to Tadros (2005) when an agent is held to account for his actions, he is required to provide an explanation. 'Why did you do this?' tends to be the most intuitive question asked, where the person who suffered the harm is requesting an explanation regarding the reasons that motivated the doer's actions. In other words, he is asked to show that his motivating reasons correspond to normative reasons: reasons that ought to have guided his actions. The relationship between motivating reasons and normative reasons can help us to understand something further about reactive attitude of the agents. $^{48}$

As highlighted, attributing responsibility for something involves holding "reactive attitudes towards the person to be held responsible... such as resentment, condemnation

\footnotetext{
${ }^{46}$ Tadros, Criminal Responsibility (2005), 25 and Duff, Answering for Crime: Responsibility and Liability in the Criminal Law (2007), 16.

${ }^{47}$ Tadros, Criminal Responsibility, 25.

${ }^{48}$ Tadros, 2005, 25. Also see Duff, Answering for Crime: Responsibility and Liability in the Criminal Law (2007), 63.
} 
as well as gratitude and approval." And these reactive attitudes "generate the social practices of passing and blaming the individual." $" 49$

In sum, and very broadly, responsibility is to hold someone(s) or an institution answerable for its acts (or negligence) when it causes some form of damage to someone other than to the accused. Thus, responsibility does not necessarily need to entail criminal responsibility. Criminal responsibility is a form of individual responsibility as we will see below. Most wrongful acts that give rise to responsibility on the part of the accused are indeed not infringements of criminal law.

From moral responsibility to criminal responsibility

Moral responsibility and criminal responsibility are intimately related. ${ }^{50}$

Normally, criminal laws tend to prescribe moral behavior. An act that is criminal is, with a few exceptions, morally condemned. ${ }^{51}$ Yet, there are some instances in which the infringement of a criminal rule may not carry the weight of moral condemnation. And for theses cases, it is common for the defense to present some form of excuse or justification for the action of the accused. Excuses, in general, aim at negating criminal responsibility altogether, while justifications act to argue against a possible incrimination (liability) yet not negating responsibility. Baron makes a clear distinction between excuses and justifications: "[T] say that an action is justified is to say... that though the action is of a

\footnotetext{
49 Tadros, Criminal Responsibility, 24.

${ }^{50}$ Duff, Answering for Crime: Responsibility and Liability in the Criminal Law (2007), 29.

${ }^{51}$ When moral behavior is equivalent to the compliance of criminal laws, which reflects the majority of cases, and the doer has indeed infringed moral acceptance, moral responsibility acts justifying some form of retribution (Waller, Bruce N, Against Moral Responsibility (Cambridge, MA: MIT Press, 2011), 2.
} 
type that is usually wrong, in these circumstances it was not wrong. To say that an action is excused, by contrast, is to say that it was indeed wrong (and the agent did commit the act we are saying was wrong), but the agent is not blameworthy.",52

Criminal responsibility necessarily involves the breach of criminal rules. Duff explains that "...criminal responsibility is a particular species of responsibility" and Tadros adds that, in fact, responsibility is a necessary condition for criminal responsibility. ${ }^{53}$ Because responsibility is understood as an act (or lack of action) which demands/asks for justification, Tadros continues, identifying "the practice of holding an agent criminally responsible for breaching the criminal law is a specific instance of the more general practice of holding agents responsible for what they do." ${ }^{\text {, }}$ Thus responsibility is to be treated as a necessary condition for criminal responsibility. ${ }^{55}$ In most cases, a criminal act also carries moral condemnation thus qualifying the accused (by our reactive attitudes) for some form of retribution. Therefore, criminal responsibility functions similarly to moral responsibility, yet it is considered a more serious infringement of moral values, and, more importantly, a direct violation of existing criminal law.

\section{Criminal responsibility and criminal liability}

When inquiring on the topic of legal responsibility one often stumbles upon the

\footnotetext{
${ }^{52}$ Baron, 'Justifications and Excuses', Ohio State Journal of Criminal Law, (2005), 389-90.

${ }^{53}$ Duff, Answering for Crime: Responsibility and Liability in the Criminal Law (2007), 36 and Tadros, Criminal Responsibility, 63.

${ }^{54}$ Tadros, Criminal Responsibility, 21.

55 Tadros, Criminal Responsibility, 63.
} 
term “legal liability." Are 'legal liability' and 'legal responsibility' synonymous? No. According to Tadros (2005) and Duff (2007) responsibility is distinct and prior to liability. A person can be held responsible for violating a rule/law, yet may not be found liable he/she is able to produce an excuse that precludes his or her responsibility. Being liable is being subject to some form of retribution. The same applies to criminal responsibility and criminal liability. Duff argues that"...being held liable is equivalent to being condemned by the referent legal authority, or authoritative organ to respond punitively to the acts committed." ${ }^{, 56}$ A person is considered liable after the authorized organ has affirmed his or her condemnation for the act in question, and no exemptions or excuses for their actions were presented or accepted. If an excuse or exemption has been in fact accepted, then the accused can be held 'criminally responsible without being criminally liable'. The presenting of exemptions or excuses functions to impede the transferal of responsibility to liability, while not necessarily eliminating criminal responsibility. In other words, the presentation of an excuse, which precludes liability, is what allows for the distinction between responsibility and liability, while not necessarily exempting criminal responsibility. ${ }^{57}$

Excuses and justification tend to affect the moral aspect of criminal responsibility as well, describing the perception of blame. For example, when a person has acted heroically saving someone's life yet damaging private/military property as an uncalculated effect, or maybe has kidnapped a person in order to save her from a life

\footnotetext{
${ }^{56}$ Duff, Answering for Crime: Responsibility and Liability in the Criminal Law, 36.

${ }^{57}$ Duff, Answering for Crime: Responsibility and Liability in the Criminal Law, 22-23.
} 
threatening situation, the damaging act was indeed performed, yet it is possible to argue against the existence of an intention to harm or of a violation of a moral rule.।

\section{Why is this topic interesting?}

Criminal law tends to function by constructing clear cut distinctions between the victim and the perpetrator. However, in working with the issue of child soldiers and criminal accountability for those who have committed gross international law breaches, this dissertation necessarily challenges this binary configuration of criminal law. A child who has committed international crimes is usually framed first as a victim even though he or she is accused of being a perpetrator. This work, therefore, calls for the creation of a category of victim-perpetrator for children old enough to be considered legally capable of exercising criminal responsibility over their acts while still potentially victims themselves.

\section{Procedures / Methods:}

The method applied for the analysis of child criminality under international law will follow the lines of Legal Positivism, aiming at the delineation of the current state of the law on the proposed problem. As explained by Bruno Simma and Andreas L. Paulus in their work 'The Responsibility of Individuals for Human Rights in Internal Conflicts: A Positivist View' (1999): a positivist approach to in a legal investigation focuses primarily on an analysis of the existent sources of law: primary and secondary sources are given priority, followed by an interpretation and explanation of the application of the relevant sources to the problem. According to the authors, a positivist approach is one which understands international law as "a unified system of rules that, according to most 
variants, emanate from state will. This system of rules is treated as an 'objective' reality and needs to be distinguished from its normative counterpart: 'as it should be'., 58

A legal positivist view of international law, implies that:

all norms derive their pedigree from one of the traditional sources of international law, custom and treaty. Treaties embody the express consent of states, custom nothing but their tacit consent. The only relevant conduct is that of states seen as unitary actors. Treaties, including so-called lawmaking treaties-e.g., those creating new rules or changing old ones-are binding upon the contracting parties only. Whether habitual conduct of states amounts to legally binding customs is a question of objective determination of fact. ${ }^{59}$

In practical terms, legal positivism offers a legal approach constructed based on the investigation of the relevant legal sources. So, first, we will be delving into International Humanitarian Rights and Human Rights treaties, as well as rules of law from these regimes that have achieved customary status regarding the recruitment and use of children in armed conflict. The next step then is to inquire into how international criminal courts define and treat the crime of child soldiering.

Also, when conducting an analysis in the area of International Criminal Law, I will be giving special attention to customary law, the law understood as binding upon all states. The choice is due to the fact that international criminal courts tend to utilize customary norms or universally binding norms as residual law, in an attempt, to fill a legal gap whenever there is no direct rule or ruling which may serve as guidance.

\footnotetext{
${ }^{58}$ Simma, Bruno, and Andreas L. Paulus, "The Responsibility of Individuals for Human Rights Abuses in Internal Conflicts," in The American Journal of International Law, (April 1999), 304. Accessed January 18, 2016. http://www.jstor.org/stable/2997991.

${ }^{59}$ Simma, Bruno, and Andreas L. Paulus. "The Responsibility of Individuals for Human Rights Abuses in Internal Conflicts," 305.
} 
Another reason is of using customary law is to avoid clashing with the principle of

legality which is also understood as a "a norm of customary international law applicable in both international and non-international armed conflicts."60

The principle of legality expresses that:

No one may be accused or convicted of a criminal offence on account of any act or omission which did not constitute a criminal offence under national or international law at the time it was committed; nor may a heavier penalty be imposed than that which was applicable at the time the criminal offence was committed. ${ }^{61}$

When no customary rules are found, the analysis extends to treaty rules, followed by principles of international criminal law, and finally general principles of international law, as explained by Cassese (2008). ${ }^{62}$ Next, I will be analyzing the Statutes and case

60 "Rule 101. The Principle of Legality", Customary IHL, ICRC, https://ihl-databases.icrc.org/customaryihl/eng/docs/v1 rul rule101, (April 26, 2017).

61 "Rule 101. The Principle of Legality", Customary IHL, ICRC: https://ihl-databases.icrc.org/customaryihl/eng/docs/v1 rul rule101, (April 26, 2017).

${ }^{62}$ As explained by jurist Antonio Cassese:

One should start by looking for treaty rules and/or rules laid down in international instruments considered binding, as, resolutions of the UNSC, as it is the case for the statutes of the international courts, when these treaty rules or resolutions contain the provisions conferring jurisdiction on the court and setting out the procedure. When such rules are lacking contain gaps, one should resort to customary law or treaties implicitly or explicitly referred to in the rules above. When even this set of general or treaty rules is of no avail, one should apply general principles of ICL, such as the principle of nonretroactivity or the principle of command responsibility. These principles can be inferred, by the process of induction and generalization, from treaty provisions or customary rules. When even the principles do not prove helpful, one could rely, as a fallback, on general principles of law (such as the principles of respect for human rights). If one still does not find the applicable rule or, more often, if the rule contains a gap or it is at any rate insufficient, one may resort to general principles of criminal law common to the nations of the world, such as the ban on denial of justice, the doctrine of res judicata...

Cassese, International Criminal Law, 14-5. 
law originated by the international criminal tribunals. A more detailed discussion of the methods applied here is to be found in the following chapter.

\section{Significance of the study}

While most works on the issue of child soldiers and criminal accountability focus on normative accounts when delving into the question of whether children should be subject to the principle of individual criminal responsibility under international criminal law for the commission of international crimes, the present work is one of the few which investigates the 'black letter of the law' to provide an answer to the above question.

A few authors, such as Happold (2005) and Grover (2012) affirm that the lack of an established minimum age of criminal responsibility in international law impedes or at least makes it hard for international courts to judge anyone below the age of eighteen. However, the research suggests that during the elaboration of the Statute of the Special Court for Sierra Leone (SCSL), the UN Secretary General with authorization of the UN Security Council has utilized what I will call 'the Minimum Age of Legal Recruitment' (MALR) of children into the military (set at fifteen) as a reference for the establishment of a minimum age of criminal responsibility at the SCSL. This suggests a correlation between the minimum age of legal recruitment as set by International Humanitarian Law and the Minimum Age of Criminal Responsibility (MACR) inaugurated by the SCSL's Statute.

The research also indicates that the SCSL Statute has indeed created evidence of law on an MACR within international criminal law that can be used by other international criminal courts and national courts adjudicating against international crimes. 
Finally, the research suggests that by including those starting at age fifteen within the jurisdiction of the court, the SCSL has recognized these children as a priori subjects of the international criminal system.

\section{Limitations of the study}

One of the main challenges when conducting this dissertation was the lack of data related to the numbers of child soldiers actively in duty, enlisted both in the armed forces and in armed groups. As stated in previous sections of this chapter, “...the total number of child soldiers in each country, let alone the global figure, is not only unknown but unknowable." ${ }^{\prime 3}$ And “...providing authoritative figures for the number of child soldiers worldwide today is nearly impossible - all numbers we quote are estimates, and even estimates are not available for all situations of conflict." ${ }^{64}$ The only numbers made available that were accessible were the names of countries that allow military recruitment by their armed forces below the age of eighteen. In some cases, even these numbers are not reliable. In some countries due to problems of birth registration, loss of paperwork, or even deliberate age blindness, countries may recruit under fifteens and register them as older. There are no viable means of getting the information on how many children are involved in armed groups. Armed groups, by definition, mostly function outside of the law, and do not register information about their personnel. Consequently, it must be

\footnotetext{
${ }^{63}$ Kassier, Glenn. "The zombie claim that 300,000 children are used as child soldiers. The Washington Post January 22, 2016.https://www.washingtonpost.com/news/fact-checker/wp/2016/01/22/the-zombie-claimthat-300000-children-are-used-as-child-soldiers/).

${ }^{64}$ Kassier, Glenn. "The zombie claim that 300,000 children are used as child soldiers. The Washington Post January 22, 2016.https://www.washingtonpost.com/news/fact-checker/wp/2016/01/22/the-zombie-claimthat-300000-children-are-used-as-child-soldiers/).
} 
understood that it is infeasible to accurately estimate the number of how many child soldiers have been involved in the commission of serious breaches of international humanitarian law.

An additional complication arising when trying to estimate the number of child soldiers employed is the fact that countries conceptualize the term child soldier in different ways. In some countries where the minimum age of legal enlistment is eighteen, for example, anyone below this age would be considered a child soldier, recruited illegally. On the other hand, if the minimum age were set at fifteen or sixteen, then a person within the stipulated allowed age, even though below eighteen, would be considered a legal soldier by the recruiting armed force. International standards set at eighteen the age below which one is a child soldier; however, these standards are not binding, and countries exercise the liberty to define their guidelines and rules. Also, the two international legal regimes that prohibited states recruiting children recognize "child soldiers' differently. For example, International Humanitarian Law recognizes children over fifteen, recruited legally as combatants, while International Human Rights Law recognizes them as maintaining their status and special protection as children.

\section{Goals}

1. Call attention to the underrepresented and unproblematized issue of child soldiers recruited legally into the armed forces

2. Highlight the Statute of the SCSL as the only international legal instrument that directly addresses the criminal liability of children accused of serious violations of International Humanitarian Law, emphasizing its creation of evidence of law on the issue. 
3. Theorize the decision of the SCSL to set fifteen as the minimum age of criminal responsibility, asking if and how the SCSL decision to grant criminal responsibility for juveniles affects, more generally, the development of a possible rule of MACR set at fifteen in International Criminal Law.

4. Develop a theoretical approach which explains the relationship between the liberty rights to enlist and individual criminal responsibility (to be developed for future research)

\section{Organization of the study}

The work is organized in eight relatively brief chapters. Following the introduction, chapter two problematizes how international discourses (sources from international organizations, international non-governmental organizations, media outlets and certain academics) represent the figure of the child soldier as a single story of a young child from the developing world who has been pressured or forced by means of violence to engage in an armed conflict, mostly against his or her will. This representation feeds into the primary discourse of the victimhood of children in the debates about child soldiers and their potential criminal accountability. The end of the chapter calls attention to the dangers of a single story representation, thus making it unfeasible to conceive other descriptions of child soldiers.

Chapter three begins setting the terms of the debate, making it clear that the research proposes a legal positivist investigation aiming at identifying, through an analysis of the legal sources of International Law and International Criminal Law, the current state of the law on the issue of children involved in the commission of 
international crimes. The chapter also clarifies that despite the importance of moral and political debates on child prosecution and the goals of international law, the research will not be delving deep into these areas.

In chapter four, the reader is introduced to a brief illustration of how currently the concept of childhood is understood in the human sciences (more specifically in Psychology) as a non-adult being in an adult-centric world, and how such descriptions affect the ways by which law makers create and enforce legal standards for children. It will be identified an overwhelming tendency of current existing debates on child soldiers of presenting themselves in normative accounts founded by liberal and universal conceptions of childhood, focusing on children's incompetence, lack of legal and moral agency, victimhood.

In chapter five, the dissertation delves into the legal analysis. Emphasis will be given to treaty and customary law developed for the protection of children, below the age of fifteen, from recruitment and use in armed conflict. This chapter calls attention to the failure of international law's provisions in completely banning the use of children between the ages of fifteen and eighteen by armed forces and armed groups, thus framing the recruitment of these children, in most cases, as complying with international customary humanitarian law, and therefore as lawful.

After having illustrated the main provisions protecting children from early military recruitment and use, chapter six presents an overview of how international law scholars structure the issue of how international law deals with the issue of child soldiers and criminal accountability. Here, it is possible to identify a shift in interpretation from a more traditional account of children's victimhood and lack of criminal responsibility 
compatible with what was presented in chapter three, into new positions which focus on interpretations of international law which license criminal accountability to those fifteen or older who have been accused of international crimes.

Chapter seven comprises the second part of the legal analysis. In it, I will present how international law, via the works of international courts, addresses those individuals who are accused of the commission of serious breaches of International Humanitarian Law and International Human Rights Law. Special emphasis is given to the Special Court for Sierra Leone for being the first international court to recognize juveniles as legally capable of infringing international law, and to include them, starting from age fifteen, within the jurisdiction ratione personae of the court.

The chapter concludes by suggesting these inclusions in the SCSL Statute reflected the UN Security Council and the UN Secretary- General's acknowledgment that juveniles accused of serious violations of international law are at least a priori considered viable subjects of the international criminal system.

The final chapter begins with a brief discussion of what it means to be a subject in the international legal system, that is, being deemed capable of infringing the rules of a legal system and thus responsible for those infringements.

It must be pointed out that International Humanitarian Law and International Human Rights Law create obligations for all individuals qua individual irrespective of age, which fulfills the most evident criterion of legal personality under international criminal law. (We will have already established in previous chapters that children are granted international legal rights under International Human Rights and International Humanitarian Law regimes). Next, the dissertation turns to a complementary line of 
thought that supports the arguments that children legally recruited according to the criteria specified by International Humanitarian Law are to be deemed legally competent to exercise both the "liberty right" of military enlistment and being subject to the principle of criminal responsibility for acts committed while in the field. The rationale sustaining this conclusion rests on the concomitant relationships between liberty rights, legal competence, and individual responsibility.

I intend to explore with greater depth the suggested relationship between the minimum age of legal recruitment and the minimum age of criminal responsibility, to develop a possible hypothesis regarding why the SCSL chose fifteen as their minimum age for criminal prosecution. It will be suggested that the underlying foundation for the linkage between the minimum age of recruitment and the minimum age of criminal responsibility is the relationship between responsibility rights and liberty rights.

Cipriani's and Hohfeld's respective theories of rights, as well as theoretical contributions from Tadros' and Duff's work on responsibility will be important sources when extending the represent research in an attempt to build a theoretical foundation to argue that liberty rights granted by International Humanitarian Law to children voluntarily starting at age fifteen is ultimately founded on the presumption of legal competence. The same presumption of legal competence is also what embodies and qualifies the juvenile for criminal responsibility. Therefore, liberty rights and responsibility coexist in a direct relationship, one enabling the other, as explained by 
Cipirani (2009) in Children's Rights and the Minimum Age of Criminal Responsibility. ${ }^{65}$ In simple terms: competence for early enlistment when granted to a young recruit, even though only presumed, gives rise, at least legally, to individual responsibility.

${ }^{65}$ Cipriani, Don, Children's Rights and the Minimum Age of Criminal Responsibility: A Global Perspective (Farnham, Surrey, England: Ashgate Publishers, 2009). 
Chapter 2: Overview of how child soldiers are represented by UN officials, international organizations and academics

At first blush, the concept of the child soldier seems an unnatural conflation of two contradictory and incompatible terms. The first, child, typically refers to a young person between infancy and youth and connotes immaturity, simplicity, and an absence of full physical, mental, and emotional development. The second, soldier, generally refers to men and women who are skilled warriors. ${ }^{66}$

This chapter offers an initial exploration on the topic of child soldiering and how international law and academics set the terms of the debate. More specifically, the chapter will show how most accounts of child soldiers presuppose universal narratives of childhood, ineptitude and victimhood 'de-territorializes' the experiences and varieties of the experiences of children and their involvement in armed conflicts. By deterritorialization I mean a type of characterization that fails to honor the diversity that arises from the multiplicity of cases of child soldiering, by creating a simple narrative, or limited narratives of the experience of child soldiering. To illustrate the lack of variance on how the phenomenon of child soldier is portrayed, I will be illustrating the main discursive constructions / images of child soldiers reproduced by the media, legal experts and academics, emphasizing how they tend to reproduce certain stereotypes which override and restricts the viability of other narratives of child soldiering and child soldiers. The difficulty of assessing the numbers of children employed in armed conflicts will also be highlighted.

\footnotetext{
${ }^{66}$ Rosen, David M, Armies of the Young: Child Soldiers in War and Terrorism (New Brunswick, NJ: Rutgers University Press, 2005), 3.
} 


\section{Images of child soldiers}

When we think of child soldiers, what usually comes to mind is an image of an African child, frequently young, holding a firearm, and with a sense of lost childhood reflected in his or her eyes. This image is widely portrayed in media outlets as depicting the phenomenon of child soldiering, yet it is not necessarily accurate. Although $40 \%$ of the cases of child soldiering are indeed placed in Africa, the rest of the countries and armed groups outside of Africa are responsible for $60 \%$ of child soldiers, despite being less visible. ${ }^{67}$ Drumbl calls attention to the need to resist "tiresome tendencies that Africanize a global phenomenon and pathologize African conflicts. ${ }^{.68}$ Neither are all child soldiers from poor, economically debilitated countries; developed countries such as the UK, Australia, and the US allow recruitment of individuals under the age of eighteen for military duty. Most of the children used in armed conflicts are from armed groups which mostly operate unlawfully; yet a significant portion of these child recruits are from governmental forces, and some have been recruited lawfully.

In order to work towards de-pathologizing the phenomenon of child soldiering away from an exclusively African or third world country experience, and widen the perspectives of the debate by providing a more diverse typology, Drumbl in 'Reimagining child soldiers' (2012) offers four main categories of child soldiers as represented by what he calls "transnational discourses." ${ }^{.69}$ These are 1) the faultless

\footnotetext{
${ }^{67}$ Drumbl, Reimagining Child Soldiers in International Law and Policy, 6.

${ }^{68}$ Drumbl, Reimagining Child Soldiers in International Law and Policy, 6.

${ }^{69}$ Transitional discourses are discourses emanating from entities influential to the characterization and treatment of the issue at hand. In the case of child soldiers I would say, particular IOs and NGOs dealing with child soldiers, children's rights, the ICRC, UN agencies, the UN organs, government officials, media,
} 
victims; 2) damaged goods; 3) the hero, 4) a demon and bandit. It is important to emphasize that these categories are ideal types. Therefore, it is highly likely to identify one or more images interposing on single cases. Fortunately, Drumbl is among the few who identifies the viability of more than one characterization of a child soldier.

The most common characterization of child soldiers delineated by Drumbl is that of a child victim: a victim of the externalities of the war, of poverty, misery, and suffering, of adults' abuses, and of their own vulnerabilities. The image of the 'faultless passive victim' abducted, coerced into service, manipulated by the adult who lacks moral rectitude, and who forces children to fight and to kill is the most widely spread image of child soldiers, especially among IOs, NGOs and media outlets. "The faultless passive victim images binds communities of conscience" and feeds into the narrative of Western humanitarianism, reinforcing the discourse that besides faultless for their acts, these children have not choice but being rescued/saved by the good will of international agencies. $^{70}$

The second image is that of the children involved in the armed conflict as 'damaged goods'; part of a lost generation, physiologically injured, traumatized and in need of being rescued. This characterization is mostly utilized by international organizations involved with the rescue and rehabilitation of child soldiers. Below, is a

academics...they all feed into what Drumbl calls the construction of a "legal imagination": "a normative, aspirational, and operational mix of international law, policy, and practice - constituted as it is directly and indirectly by a broad constellation of actors." (Drumbl, Reimagining Child Soldiers in International Law and Policy, 9).

${ }^{70}$ Drumbl, Reimagining Child Soldiers in International Law and Policy, 8-9. 
part of a letter sent by Human Rights Watch Executive Director, Peter Takirambudde, to

Sierra Leonean President Kabbah in 1999 on the recruitment of child soldiers.

Emotionally and physically immature, children are ill-equipped to deal with the harsh realities of armed conflict. Because of their inexperience and lack of training, child soldiers suffer far higher casualty rates than their adult counterparts. Those who survive may be permanently disabled or bear psychological scars from being forced to both commit and witness horrific atrocities. Former child combatants often require much more intensive rehabilitation and reintegration services than adult soldiers following a conflict. Often denied an education and the opportunity to learn skills that are beneficial to civilian society, former child combatants are often drawn back into conflicts and are easy prey for armed groups and criminal gangs. ${ }^{71}$

The third image is of a demon and / or bandit, a child who is: irredeemable, baleful, or sinister; an instrument of war manipulated by adult malefactors. Child soldiers can be regarded as beasts with no mercy and no moral standing. Some are even framed as delighted by the power that comes from holding the position of a soldier and owing a firearm, while others seem entertained by all of the violence they are capable of executing. Child soldiers were "... feared by many for their brutality." " "These new soldiers are not simply children; they can also be callous killers capable of the most terrible acts of cruelty and brutality., ${ }^{, 73}$ The image of a child soldier as a demon and bandit is mostly commonly promoted by people and societies who have witnessed and suffered the violence committed by these young soldiers.

\footnotetext{
71 "Letter to Sierra Leonean President Kabbah on the Recruitment of Child Soldiers" (1999), https://www.hrw.org/news/1999/05/03/letter-sierra-leonean-president-kabbah-recruitment-child-soldiers.

${ }^{72}$ Report of the Secretary-General on the establishment of a Special Court for Sierra Leone, S/2000/915 (4 Oct. 2000), http://www.rscsl.org/Documents/Establishment/S-2000-915.pdf.

${ }^{73}$ Singer, Peter W, "Child Soldiers: The New Faces of War," in Brookings Institution (2005), 14.
} 
The fourth and last image is of a child soldier as a hero. Someone who has sacrificed himself to join a morally urgent fight, for example, a young soldier who has joined the resistance to fight against external oppression. Commonly, the images of young soldiers as heroes are mostly propagated by armed forces and armed groups to target possible recruits in similar hardship.

I have chosen to use Drumbl's typology because it is possible to identify these 'ideal type' characterizations in most discourses about child soldiers. Overall, Drumbl's typology calls attention to the overwhelming presence of the first two images of child soldiers: the 'faultless victims', and 'damage goods;' as we will see in the section below.

\section{Child soldiers as described by international organizations}

Specialized IOs and NGOs working with child soldiers produce and publicize a body of literature that is considered authoritative by many, despite those groups' political interest in the issue. In this section, it will be shown, as an example, how a few main IOs and NGOs that work with children in armed conflicts share a set of perceptions of how they perceive and categorize child soldiers.

Child Soldier International is the leading NGO addressing the problem of child soldiering. The organization also works towards ending the military recruitment of persons under eighteen. It recognizes child soldiers as "children (under eighteen) who are used for military purposes.",74

\footnotetext{
74 "Who are the child soldiers?," Child Soldiers International (Last accessed April 26, 2017), https://www.child-soldiers.org/child-soldiers-war-conflict-what-where-who-why
} 
Child Soldier International functions with a broad definition of child soldier that aligns

with the conceptualizations offered by the Cape Town Principles and the Paris

Principles. $^{75}$

The organization's website, under the title "What are Child Soldiers?" describes

child soldiers as mostly victims of abused by their commanders, forced to commit violent

acts, to kill, to follow any rule despite their moral judgment.

Some child soldiers are used for fighting - they're forced to take part in wars and conflicts, obliged to kill, and commit other acts of violence. Some are compelled to act as suicide bombers. Some join 'voluntarily,' driven by poverty, sense of duty, or circumstance... Child soldiers can be both boys and girls. While some may be in their late teens, others are as young as four years old. ${ }^{76}$

The strategic use of the word 'some' to indicate the possibility that not all are submitted to this type of violent treatment, yet the organization fails to offer an alternative description of what a child soldier may encounter when they are recruited to duty.

\footnotetext{
75 "Who are the child soldiers?," Child Soldiers International, ((Last accessed April 26, 2017) https://www.child-soldiers.org/child-soldiers-war-conflict-what-where-who-why.
}

The Cape Town Principles (1997) and the Paris Principles (2007) were the products of conventions held to determine State guidelines when dealing with children involved in armed conflicts. These conventions, despite not generating binding obligations on the part of the State "consolidated global humanitarian knowledge and experience in working to prevent recruitment, protect children, support their release from armed forces or armed groups and reintegrate them into civilian life" and were essential to set guidelines and principles which effectively influence the legal debate on child soldiers, as well as future treaties on the topic. In other words, there conventions were central in setting the stage for the development of the treaties aimed at the protection of children in times of war. (UNICEF, "Child protection from violence, exploitation and abuse: Paris principles and Paris commitments," https://www.unicef.org/protection/57929_58012.html).

76 "Who are the child soldiers?," Child Soldiers International (Last accessed April 26, 2017), https://www.child-soldiers.org/child-soldiers-war-conflict-what-where-who-why 
The word "voluntarily" is presented between quotation marks, indicating that the organization does not believe that child soldiers can be entitled to a genuine choice to enlist. For this reason, CSI legal adviser Tomaso Falchetta has expressed the view that: "child soldiers should be considered as victims and the NGO opposed their prosecution, as emphasis should be on the criminal responsibility of the adult recruiter... The CSI does not advocate for a cutoff point for the prosecution of child soldiers, as it is a difficult issue." 77 Child Soldier International expresses the opinion that even when recruitment is done lawfully, it is still to de condemned because it "puts [children] at undue risk and jeopardizes their human rights"

Child Soldier International may be among the very few NGOs that recognizes the fact that at least one developed country, Great Britain, recruits underage soldiers into its armed forces as standard policy. "Child soldiers are recruited and used by both official government armed forces and armed groups around the world... Today, most state armed forces worldwide only recruit adults (from age eighteen). But some countries still recruit children under the age of eighteen - for example the UK, Myanmar, and Afghanistan” which would technically, as we will see in the coming chapters, qualify as a child soldier. $^{79}$

Human Rights Watch offers a more explicit victimized characterization of child soldiers, framing the child soldier as an underprivileged child from a developing country,

\footnotetext{
${ }^{77}$ IRIN, "Should child soldiers be prosecuted for their crimes?" (October 6, 2011), http://www.irinnews.org/analysis/2011/10/06/should-child-soldiers-be-prosecuted-their-crimes.

${ }^{78}$ Child Soldier International, “Child Recruitment,” https://www.child-soldiers.org/child-recruitment.

${ }^{79}$ Child Soldier International, “What are child soldiers?”, https://www.child-soldiers.org/about-the-issue.
} 
suffering from poverty, war, fear, lacking opportunities, and more commonly than not, severely abused and taken advantage of. The involvement of the child with the armed conflict is mostly a product of abduction, forcible recruitment, or an act of desperation on the part of the child. The possibility of voluntary enlistment into armed conflict is represented as nonexistent.

Thousands of children are serving as soldiers in armed conflicts around the world. These boys and girls, some as young as eight years old, serve in government forces and armed opposition groups. They may fight on the front lines, participate in suicide missions, and act as spies, messengers, or lookouts. Girls may be forced into sexual slavery. Many are abducted or recruited by force, while others join out of desperation, believing that armed groups offer their best chance for survival. ${ }^{80}$

The organization published several reports about child soldiers in which it explores the lives of child soldiers, both from armed groups and from armed forces in South Sudan, Syria, Yemen, Somalia, India's Chhattisgarh State, Congo, Chad, Nepal, Sri Lanka, Burundi, Liberia, Sierra Leone, Côte d'Ivoire, Guinea, Colombia, Northern Uganda, Angola, Burma ranging from years 2003 to 2015. All countries in the report were from the developing world, facing serious economic and security challenges. In addition, the children focused fit the stereotype of an underprivileged child suffering from poverty, war, fear, lack of opportunities. There were no reports of developed countries that enlist or recruit underage soldiers. ${ }^{81}$

The Office of the Special Representative of the Secretary-General for Children and Armed Conflict of the United Nations characterizes child soldiers as children, in high

\footnotetext{
${ }^{80}$ Human Rights Watch, "Child Soldiers," https://www.hrw.org/topic/childrens-rights/child-soldiers.

${ }^{81}$ List of reports published by Human Rights Watch available at: https://www.hrw.org/publications?keyword=UK\&date[value][year]=\&\&topic[0]=9712.
} 
numbers: "hundreds of thousands... used in armed conflicts around the world... [who] are abducted and beaten into submission, others join military groups to escape poverty, to defend their communities, out of a feeling of revenge or for other reasons." The Office also holds that children who have become child soldiers are "victims" "regardless of how children are recruited and of their roles... "their participation in conflict bears grave consequences for their physical and emotional well-being. They are commonly subject to abuse and most of them witness death, killing, and sexual violence. Many are forced to perpetrate these atrocities, and some suffer serious long-term psychological consequences. The reintegration of these children into civilian life is a complex process. ${ }^{, 82}$

UNICEF, the agency of the United Nations dedicated to improving the health and nutrition of children and mothers throughout the world describes the urgent situation of child soldiers as: "Children as young as eight years of age are forcibly recruited, coerced and induced to become combatants. Manipulated by adults, children have been drawn into violence that they are too young to resist and with consequences they cannot imagine. ${ }^{93}$

\footnotetext{
${ }^{82}$ The Office of the Special Representative of the Secretary-General for Children and Armed Conflict of the United Nations, "Child Recruitment and Use," https://childrenandarmedconflict.un.org/effects-ofconflict/six-grave-violations/child-soldiers/.

${ }^{83}$ Cataldi, Anna and Jimmie Briggs, "Child Soldiers" in Crimes of War (2011), http://www.crimesofwar.org/a-z-guide/child-soldiers/.
} 
When considering how children end up in armed groups and armed forces, UNICEF explains that "child soldiers are recruited in many different ways. Some are conscripted, others are press-ganged or kidnapped, and still others are forced to join armed groups to defend their families. Sometimes, children become soldiers simply to survive. ${ }^{\prime 84}$

Common features of how international legal discourse describes child soldiers

Children are legally framed as in need of special protection due to their vulnerabilities. The Convention on the Rights of the Child (CRC) reaffirms the belief - as indicated in the Declaration of the Rights of the Child - that

the child, by reason of his physical and mental immaturity, needs special safeguards and care, including appropriate legal protection, before as well as after birth... [and that] the need to extend particular care to the child has been stated in the Geneva Declaration of the Rights of the Child of 1924 and in the Declaration of the Rights of the Child adopted by the General Assembly on 20 November 1959 and recognized in the Universal Declaration of Human Rights, in the International Covenant on Civil and Political Rights (in particular in articles 23 and 24), in the International Covenant on Economic, Social and Cultural Rights (in particular in Article 10 ) and in the statutes and relevant instruments of specialized agencies and international organizations concerned with the welfare of children. ${ }^{85}$

International Humanitarian Law affirms that children affected by armed conflict are entitled to special respect and protection, as first expressed in Geneva Convention IV, then later in Additional Protocols I and II. These conventions codify special protection awarded to children during conflict: "the requirement of special protection for children

\footnotetext{
${ }^{84}$ Cataldi, Anna and Jimmie Briggs, "Child Soldiers" in Crimes of War (2011), http://www.crimesofwar.org/a-z-guide/child-soldiers/.

${ }^{85}$ Convention on the Rights of the Child, "Preamble," para. 8 and 9 (1989).
} 
relates to the provision of food, clothing and tonics, care of children who are orphaned or separated from their families, treatment during deprivation of liberty and the distribution of relief consignments and can be found throughout the Fourth Geneva Convention and in Additional Protocol I (Fourth Geneva Convention, Articles 23-24, 38, 50, 76 and 89 (cited in Vol. II, Ch. 39, §§ 139-144); Additional Protocol I, Article 70(1).” Additional Protocol I also determines that: "children shall be the object of special respect" (Article 77(1)) and Additional Protocol II adds that: "children shall be provided with the care and aid they require" (Article 4(3)). ${ }^{86}$

Large parts of the available material on child soldiers focus on crimes committed against children and not by children. Identified by the UN Secretary General and enumerated by the Security Council in its resolutions, forming the basis of the Council's architecture for protecting children during war, International law frames six grave violations against children during times of armed conflict. ${ }^{87}$ These six violations are: the recruitment and use of children; killing or maiming of children; sexual violence against children; attacks against schools or hospitals; abduction of children, denial of humanitarian access. ${ }^{88}$

\footnotetext{
${ }^{86}$ ICRC, "Rule 135. Children,” Customary IHL Database, https://ihl-databases.icrc.org/customaryihl/eng/docs/v1 cha chapter39 rule135.

${ }^{87}$ The Office of the Special Representative of the Secretary-General for Children and Armed Conflict "Working Paper N.1: The Six Grave Violations Against Children During Armed Conflict: The Legal Foundation," 2009, 2013 https://childrenandarmedconflict.un.org/publications/WorkingPaper1 SixGraveViolationsLegalFoundation.pdf.

${ }^{88}$ The Office of the Special Representative of the Secretary-General for Children and Armed Conflict "Working Paper N.1: The Six Grave Violations Against Children During Armed Conflict: The Legal Foundation," The Office of the Special Representative of the Secretary-General for Children and Armed Conflict, 2009, 2013 https://childrenandarmedconflict.un.org/publications/WorkingPaper-

1 SixGraveViolationsLegalFoundation.pdf.
} 
The legal basis for these violations lies in relevant international law, which in turn encompasses international humanitarian law, international human rights law and international criminal law. During armed conflict, international humanitarian law and international human rights law must be respected, with special regard to children who often have no means to defend themselves against abuses. The full range of children's rights, economic, social and cultural as well as political and civil, must be respected, protected and fulfilled. ${ }^{89}$

More specifically related to child soldiering, the Statutes of the International

Criminal Court and the Special Court for Sierra Leone have labeled the recruitment and use of children under the age of fifteen by armed forces and armed groups, a war crime.

The criminal responsibility falls exclusively upon the adult recruiter. If the child is accused of an international crime, international law is unclear regarding the status of the child as possible perpetrator; that is, whether the child is criminally responsible..$^{90}$

International courts and domestic courts applying international law have yet to bring a child to trial for international crimes.

\footnotetext{
${ }^{89}$ The Office of the Special Representative of the Secretary-General for Children and Armed Conflict "Working Paper N.1: The Six Grave Violations Against Children During Armed Conflict: The Legal Foundation," 2013, 9, https://childrenandarmedconflict.un.org/publications/WorkingPaper1 SixGraveViolationsLegalFoundation.pdf.
}

As established by Office of the Special Representative of the Secretary-General for Children and Armed Conflict, Working Paper \#1: The Key Legal Sources for the Six Grave Violations in International Law are found in: the Four Geneva Conventions (1949); Additional Protocols to the Geneva Conventions (1977); Rome Statute of the International Criminal Court (1998); Customary international humanitarian law. In International human rights: The Convention on the Rights of the Child (1989) and its Optional Protocols (2000/2012); UN Declaration of Human Rights (1948); International Covenant on Civil and Political Rights (1966); International Covenant on Economic, Social and Cultural Rights (1966); Regional human rights instruments; ILO Conventions 29 (1930) and 182 (1999) Convention against Torture (1984); Customary international human rights law. In International jurisprudence established by: Case law of the International Criminal Tribunal for the former Yugoslavia, International Criminal Tribunal for Rwanda and the Special Court for Sierra Leone; The Rome Statute and case law of the International Criminal Court and Case law of the International Court of Justice Security Council Resolutions on children and armed conflict 1261 (1999), 1314 (2000), 1379 (2001), 1460 (2003), 1539 (2004), 1612 (2005), 1882 (2009), 1998 (2011) and 2068 (2012).

\footnotetext{
${ }^{90}$ Brons, Kathryn, Assessing the Innocence and Victimization of Child Soldiers. Master's Thesis. University of Alabama, 2013. Tuscaloosa, AL, 2013. 1-

59.http://acumen.lib.ua.edu/content/u0015/0000001/0001380/u0015_0000001_0001380.pdf.
} 
Children are generally recognized as victims of war, even when they are perpetrators. They are represented as victims of abuse from adult recruiters and commanders and from the distress of war. International organizations have constructed a discourse of child soldiers that is based exclusively on the quality of victimhood of the child, even if the child is the one perpetrating the acts: "Children, if anyone, should be considered victims of armed conflict and protected accordingly. The assumption of a relationship between victimhood and childhood is prevalent in the literature on the status of children in war... in the context of war, children are seen as a product of abuse, maneuvered by adult malevolence, presupposing that children are "dependent, exploited, and powerless. ${ }^{.91}$

The Paris Principles declared that if children under 18 years who are unlawfully recruited or used by armed forces or groups are accused of crimes against international law are to be considered primarily as victims of violations of international law. Even if they have been accused of serious offenses they are to be treated in accordance with international standards for juvenile justice. ${ }^{92}$

As exemplified, the victimization of child soldiers is a commonplace among NGO and UN discourses. Former UN Secretary General Kofi Annan, in the 2002 Report of the Secretary-General on the establishment of a Special Court for Sierra Leone declared that: although the children of Sierra Leone may be among those who have committed the worst crimes; they are to be regarded first and foremost as victims".... More than in any other conflict where children have been

\footnotetext{
${ }^{91}$ Vaha, Milla , and Leena Vastapuu. "Rafting Muddy Waters: Girl Soldiers and Complex Moral Agencies." Paper prepared for International Studies Association Annual Convention, Atlanta, March 16-19, 2016, 2.

${ }^{92}$ Commitment 11 of the Paris Principles.
} 
used as combatants, in Sierra Leone, child combatants were initially abducted, forcibly recruited, sexually abused, reduced to the slavery of all kinds and trained, often under the influence of drugs, to kill, maim and burn. $^{93}$

Children should not be held criminally accountable for criminal violations. The position against child prosecution is a common one. Rosen (2005) and Grover (2012), for example, both argue that children should be exempt from exercising criminal responsibility for any violations they have committed. For Rosen (2005) “children lack moral agency, [therefore] cannot be held responsible for the war crimes they commit because they are considered to have no legally relevant agency.",94

Following the same line of thought, Grover (2012) argues that children involved in armed forces and armed groups are to be framed exclusively as victims, even when they have committed hideous crimes. Their lack of responsibility is due to the coercive condition under which they act and the threat of violence they face if they attempt to refuse the order given. Even when the of the child is formally considered a volunteer, she or he is usually reacting to the contextual or/and explicit violence which forces them to serve in the first place; thus enlistment should not be seen not as the exercise of choice, rather a survival strategy, or a way to keep their family and loved ones safe and fed:

The issue of duress is ever present in child soldier cases (where the child is accused of having committed grave conflict-related international crimes) even if one assumes that allegedly the child 'voluntarily' joined the armed group or force committing mass atrocities and genocide ${ }^{95}$

\footnotetext{
${ }^{93}$ UN Secretary-General Kofi Annan on the Report of the Secretary-General on the establishment of a Special Court for Sierra Leone (2000), http://www.refworld.org/docid/3ae6afbf4.html.

${ }^{94}$ Rosen, Armies of the Young: Child Soldiers in War and Terrorism, 297.

${ }^{95}$ Grover, Sonja C, Child Soldier Victims of Genocidal Forcible Transfer Exonerating Child Soldiers Charged with Grave Conflict-related International Crimes (Berlin: Springer, 2012), 76.
} 
Finally, Grover (2012) frames the responsibility of child soldiering as falling on both the adult recruiters who take advantage of the fragile state of the child, and the State which has failed to protect the child from being recruited and used in the first place. In her opinion, allowing children to be recruited and used for military purposes violates international legal principles such as the "special protection of the child in times of conflict" guaranteed by Additional Protocols I and II, the CRC and the OPAC, as well as the principles of life, development, best interest of the child also codified by the CRC.

Similarly, Singer argues that the entire process of recruitment and training serves the purpose of indoctrination, utilizing tactics of "fear, brutality, and psychological manipulation to achieve high levels of obedience ...harsh discipline and the threat of death continue to underscore the training programs of almost all child soldier groups. ${ }^{96}$ Grover adds to Singer's comments on harsh recruitment techniques that even when the service of the child is formally considered voluntary, she or he is usually reacting to the violence that submits them to serve in the first place, and to the violence, they have been submitted by the training process. ${ }^{97}$ Aptel (2010) also asserts that children who have participated in international crimes should also be considered primarily as victims, especially when the circumstances surrounding these offenses are inherently coercive.

\footnotetext{
${ }^{96}$ Singer, "Child Soldiers: The New Faces of War," 2005, 28-9.

${ }^{97}$ Grover, Sonja C, Child Soldier Victims of Genocidal Forcible Transfer Exonerating Child Soldiers Charged with Grave Conflict-related International Crimes (Berlin: Springer, 2012), 31.
} 
It is important for children to emerge as a recognized category of victims because the process acknowledges and empowers them. It is essential to break away from an adult-centric understanding of international crimes and recognize that, in numerous contexts, victims and witnesses of international crimes are children, and as children, they have specific rights and specific needs. ${ }^{98}$

As one can see, in most of the literature dedicated to child soldiers, these children

are framed as lacking agency, maturity, and competence, thus being considered incapable

of choice. Such a position is evident in the discussion of voluntary enlistment, in which

the child's decision to join the armed conflict is greatly influenced by push and pull

factors, and therefore cannot be representative of a genuine expression of free will.

Children are drawn into armed conflict by both push and pull factors. Push factors include negatives that children escape by joining an armed group. Abuse suffered in the family is a push factor - the child might join an armed group to escape an abusive situation. They may also seek to escape boredom, physical insecurity, extreme poverty, and the humiliation associated with personal or family victimization and shame. These push factors are only partial causes since most children who have difficult family situations or live in abject poverty do not become child soldiers. Equally or more compelling are the pull factors, which are the positive rewards or incentives for joining armed groups. Analysts have tended to underestimate the importance of pull factors, probably because the emphasis of much child-soldiering literature has been on protecting children from exploitation. Although most analysts view child soldiering as a heinous form of exploitation, children who join armed groups often see soldiering in different terms. Many see it as entering an opportunity space in which they can obtain things they could not obtain otherwise including a family, power, revenge, wealth, education, and a commitment to a cause. To understand the lure of these incentives, one has to imagine the attraction felt by a child who comes from a very low-income family and who has always felt powerless but who now carries a gun and is feared and respected by many. ${ }^{99}$

\footnotetext{
${ }^{98}$ Aptel, Cecile, "Children and Accountability for International Crimes: The Role of the ICC and other international and mixed jurisdiction," Innocenti Working Paper (August 2010), vi.

${ }^{99}$ Poulatova, Chaditsa, Children and Armed Conflict, (Newcastle-upon-Tyne, United Kingdom: Cambridge Scholars Publishing, 2013), 6. Web. 3 October 2016.
} 
Rivet goes beyond stating that "regardless of whether these children are forcibly recruited or joined the armed forces voluntarily out of fear, they are left with no choice, but to commit such crimes to survive."100

Answering to Rivet, joining the armed forces to survive, and being left without a choice but to commit atrocities is too strong of a statement, and does not translate well all the cases of child soldering. Children who have been lawfully recruited before eighteen by the armed forces of developed countries like the UK, Australia, and the US, for example, are understood to not fit this description.

The current legal imagination regarding abduction and coercive recruitment as the major ways that children join armed forces and armed groups "leads to the undertheorization and under exploration of youth volunteerism." ${ }^{101}$ It is presumed that children are incapable of volunteering to join the armed forces due to an alleged lack of competence and choice, and as a result, "the very notion of voluntary recruitment is largely an illusion." 102 Also, in discussions related to children's capacity, the minors are mostly regarded as a uniform group; for example, in very few works authors differentiate between younger and older children's capacity for decision-making, an essential point when discussion the young's competence towards the genuine exercise of choice.

\footnotetext{
${ }^{100}$ Rivet, Annabelle Karen, The Criminal Liability of Child Soldiers in International Criminal Law: Does Restorative Justice Offer a Balance Between the Rights of the Victim and the Right of the Child Perpetrator?, LLM diss., (Pretoria: University of Pretoria, 2014), 22.

${ }^{101}$ Drumbl, Reimagining Child Soldiers, 13.

${ }^{102}$ Hart, Jason, "Saving Children: What Role for Anthropology?" Anthropology Today 22, no. 1 (February 2006): 1-8. Accessed January 05, 2016. http://anthro.vancouver.wsu.edu/media/Course files/anth-302barry-hewlett/hart-saving-children.pdf.
} 


\section{Hart's divergent position}

Jason Hart, in his article, "Saving Children: What Role for anthropology?" offers an alternative, more critical perspective. The author calls attention to how the current literature on child soldiers tends to produce a discourse which de-contextualizes and thus, deterritorializes the experience of competence of the children involved. Hart defends the point that: "representational practices of child-focused humanitarianism on the grounds... influence popular understanding of children's lives, as well as the political uses to which such representations may be put." ${ }^{103}$ As an example, he illustrates Singer's book "Children of War" (2005):

We are given a generic account of 'child soldiers' in which the appalling experience of one individual stands for all...A tone of indignation at the adults who encourage children to take up arms to such effect pervades this prime example of a humanitarian discussion of child soldiers. Noting that technological developments and socio-economic conditions combine to make the employment of children as combatants attractive, Singer remarks that ' $[\mathrm{t}] \mathrm{he}$ only remaining ingredients required are groups or leaders without scruples[...] As the payoffs can be huge, many take this moral plunge. ${ }^{104}$

In Hart's opinion, "the above statement is typical of a book in which the moral landscape extends only as far as the borders of the state. ${ }^{105}$ Hart criticizes authors who engage in what he calls a "global account of child soldiers," disqualifying the child for any "real measure of choice about recruitment."106

\footnotetext{
${ }^{103}$ Hart, "Saving Children: What Role for Anthropology?"

${ }^{104}$ Singer, Children at War, 56.

${ }^{105}$ Hart, "Saving Children: What Role for Anthropology?" 6.

${ }^{106}$ Hart, "Saving Children: What Role for Anthropology?" 7.
} 
My problematization follows the line of Hart's argument, directed against the urge of understanding and treating the problem of child soldiering as represented by one ideal type of child soldier: a young child forcibly abducted by armed groups, and thus victimized by war and human violence. Most traditional approaches to child soldiers and criminal accountability fails to provide proper representation of the numerous facets of child soldiering.

Also, it is widely held that recruitment of young children (below the age of fifteen), besides being legally prohibited by international law, is also morally condemned by international society as a whole. Conversely, the early enlistment of individuals under the age of eighteen to the armed forces for most parts does not cause equal repugnance. In most cases, it is part of the official military policies and not labeled as a practice of child soldiering. As a conclusion, the current and most common images/descriptions of child soldiers are exclusionary, failing to reflect the reality of an older child (age fifteen, sixteen, seventeen) officially recruited to join the armed forces and which have done so as an exercise of choice and not as a desperate attempt to survival.

The current chapter has provided an overview of the main characterizations of child soldiers, calling attention to the dominant discourses that encapsulate and reinforce a single perspective. 
Chapter 3: Initial remarks and a note on methodology and the sources of International Law

The general aim of this dissertation is to conduct a legal investigation to determine whether international law recognizes the individual criminal responsibility of a person who is under the age of eighteen. Secondly, a more specific aim is to inquire into the role of the Special Court for Sierra Leone's contribution to the development of a legal norm of minors' criminal responsibility under international law. With both issues, my primary concern will be identifying whether there is law to guide the topic at hand, and if so, where the law is to be found. Lastly, I am also interested in determining whether the place where the law is situated affects its interpretation and use. For the present investigation, I will be using a legal positivist approach that understands and utilizes the sources of international law (as recognized by international courts) as tools of analysis.

In practical terms, legal positivists understand the sources of law as the foundation of a legal system and thus valuable guideposts to where the law is to be found. This way, starting a legal analysis by identifying the legal sources applicable to the referent question/case makes good sense. A legal positivist also views the law as a source-based legal system in which the validity of legal rules emanates from their legal rules. This affirmation, however, is not the same as saying that legal sources are the only factors which determine legal rulings, and legal positivism does not ignore non-legal factors such as accounts of morality, justice, political considerations, or how these enter into the making of international law and courts' decisions on specific cases. When non-legal factors are brought within legal reasoning, and used by courts, they tend to be 
incorporated as part of the existing legal resources due to the doctrine of precedent. ${ }^{107}$ Nonetheless, it still makes sense to start a legal analysis by inquiring into the sources if one is interested in identifying whether there is law on the issue and where it is located.

One of the most common criticisms addressed to positivism is its disassociation from moral and political accounts of how law is created and operates. ${ }^{108}$ "A theory that insists on the facticity of law seems to contribute little to our understanding that law has important functions in making human life go well, that the rule of law is a prized ideal, and that language and practice of law is highly moralized." 109 Yet, as mentioned in the previous paragraph, a legal positivist approach does not ignore non-legal factors or their influence on courts' decisions. "It is beyond doubt that moral and political considerations bear on legal philosophy... the reasons we have for establishing, maintaining or reforming law include moral reasons, and these reasons, therefore, shape our legal concepts. ${ }^{110}$ The current analysis rather identifies the law by its sources, and not its merits, therefore I will not be inquiring into whether the legal rules under investigation are morally justified.

In other words, by working within a legal positivist framework, I will not be developing a normative approach of how international law ought to be applied to reach a specific desired outcome on the topic of child solders and accountability. My exclusive

\footnotetext{
${ }^{107}$ Green, Leslie, "Legal Positivism," in The Stanford Encyclopedia of Philosophy (2009), 7. Accessed March 24, 2017. https://plato.stanford.edu/archives/fall2009/entries/legal-positivism/.

${ }^{108}$ Green, "Legal Positivism" (2009), 5.

${ }^{109}$ Green, "Legal Positivism” (2009), 5.

${ }^{110}$ Green, "Legal Positivism" (2009), 5. See also: Finnis, John, "The Truth in Legal Positivism" in The Autonomy of Law, ed. Robert P. George (Oxford: Clarendon Press, 1996), 204.
} 
concern is with the 'black letter of the law', and more specifically, with the question of whether international criminal law recognizes children as subjects of the principles of individual criminal responsibility if accused of committing serious breaches of international humanitarian law.

It should be noted that I recognize that most discussions related to child soldiers and accountability currently available are normatively driven. In transitional justice, for example, the question of children's criminal accountability revolves around the question whether child soldiers should face prosecution for their legal wrongdoing, and whether any type of retribution is fair, and lastly if such a course is effective or detrimental for that society's transition from war to peace. These interrogations lead to a moral debate regarding the minor's subjection to criminal liability and, and under what criteria liability can exist. Experts and academics have not been able to reach a consensus on the issue; some assert that bringing a minor to trial for alleged crimes is neither efficient nor fair. They argue that children under eighteen, in most cases, do not have a full understanding of their actions and consequences. Therefore, if any type of accountability is recommended, it should be rehabilitation and not punishment. Others bring direct their attention to the victims, arguing that victims of minors' violence are equally entitled to justice, and that bringing perpetrators to trial, besides reinforcing the institution of justice in that specific society, offers those who have suffered the crimes and their families a sense of closure. As a conclusion, most of the analysis and work published up to date approaches the matter as a substance of normative / principled interpretation, addressing the question of how the current law should be interpreted. The normative approach is due to the fact that high principles embedded with universal accounts of childhood, such as 
immaturity, lack of emotional control and agency, incompetence, lack of individual responsibility greatly influence and inform the debate on child soldiers. On the following chapter, I will highlight how most approaches focus on principled interpretations of the law, bringing into their accounts moralized and universalized conceptions of how the issues should be treated legally. When I analyze the principled accounts my goal is simply to illustrate an existing dissonance between where the law is and where a handful jurists and academics argue it should be.

Why is it important to utilize a legal positivist approach when conducting a legal analysis?

It is common to find in transnational discourses reflected by UN officials, other non UN-IOs, NGOs and specialized literature, moral, political and even presumed legal positions of what is to be understood as morally fair and appropriate on the legal treatment of child soldiers. However, most of these accounts fail to give a more careful consideration of the where the current black letter of the law related to these young combatants stands. Even if one's goal is to make normative statements about the law, an analysis of where the law stands seems to be a fundamental first step. This being, an inquiry into the sources of the law pertinent to the case is customary to jurists and courts alike when adjudicating or even investigating a specific topic. I cannot emphasis enough the importance of establishing first an investigation on the sources of law before one can interpret and apply the fitting rules to the case at hand.

The sources of International Law

International law, unlike national legal systems, is a decentralized arrangement of legal rules mostly built by commitments states establish with each other on a voluntary 
basis. states, therefore, chose to engage in legal relationships, for many reasons such as creating a cooperative structure to solve multilateral problems, prescribing certain rules to avoid conflict and confrontation, establishing reciprocity, instituting minimum levels of protection to individuals, etc. The sources of international law are the building blocks of the international legal system; they answer the questions "where does international law come from and how is it made?" 111 In practice, whenever a court, jurist, or even an academic seeks to investigate whether there is a law on a particular issue and where that law is found, they work to identify which sources of law are pertinent to the issue.

Article 38 of the ICJ Statute lists the five primary source of international law considered by the Court: international treaties, customary law, general principles of law, judicial decisions, and the writing of publicists. Despite the ICJ indicating that there is no existing hierarchy among the listed sources, courts and jurists assign priority to international treaties and customary law when conducting legal inquiry, because these are lawmaking sources; that is, sources that directly generate international obligations. The other sources are commonly utilized when a lack of treaty law and customary law is evident, and to provide complementary guidance on how the law found in treaty or custom is to be interpreted and applied. The current work will also give preference to treaties and customary law when analyzing whether international law provides a legal answer to the issue of children's criminal responsibility.

\footnotetext{
${ }^{111}$ Greenwood, Christopher, "Sources of International Law: An Introduction,” (2008), http://legal.un.org/avl/pdf/ls/greenwood outline.pdf).
} 


\section{International treaties}

Treaties are the most common form of written commitments developed in the international community. Treaties are governed by international law and are intended to create a legal obligation. ${ }^{112}$ A treaty needs to be ratified / acceded to by a state for it to create binding legal obligations for that State. When a state has ratified a treaty, it is obligated to incorporate the treaty's provisions into its domestic legal system, which ultimately allows state parties' national courts to rule on questions of international law, if deemed necessary.

Evidence of the legal relationship established between states is found, for example, in the numerous treaties established by states throughout history. Since the creation of the United Nations "...more than 500 multilateral treaties have been deposited with the Secretary-General of the United Nations. ${ }^{113}$ Many other treaties are deposited with governments or other entities." 114

The development, implementation, and interpretation of treaties are regulated by the Vienna Convention on the Law of Treaties developed in 1969. The provisions found in the VCLT were mostly already customary rules. The VCLT does not apply to treaties established before 1969 (the VCLT does not have a retroactive effect) apart from those rules that had already achieved customary status. Three fundamental principles of international law codified in the VCLT establish the foundations for how treaties are to

\footnotetext{
${ }^{112}$ Kaczorowska, Alina, Public International Law (Abingdon, Oxon: Routledge) 2010, 92.

${ }^{113}$ Treaties are written commitments developed and engaged by states (parties of the treaty). A treaty needs to be ratified/accessed by the state to become an obligation.

${ }^{114}$ For more information, see: http://www.un.org/en/globalissues/internationallaw/.
} 
be created, implemented and interpreted. These three principles are the Principle of Consent, the principle of pacta sunt servanda, and the Principle of Good Faith.

The Principle of Consent can be found in Articles 34-36 of the VCLT; it expresses that a state shall only be bound by a treaty to which it has consented to it. As a consequence, treaties do not bind non-party or "third" states, except for any specific treaty rules which have been recognized as codifying existing customary law. ${ }^{115}$

Article 26 of the VCLT reflects the principle of pacta sunt servanda, and it lays out that: "every treaty in force is binding upon the parties to it and must be performed in good faith.” In Latin, pacta sunt servanda means "agreements must be kept;" this applies to all legal treaty commitments made by state parties. Article 26 also mentions that states must observe the treaty and act in good faith, thus exposing the significant concomitant relationship between the principles of pacta sunt servanda and good faith. ${ }^{116}$ The principle of good faith, even though explicitly present in the VCLT extends beyond this treaty, serving as the foundation of all international obligations emanating from international law. ${ }^{117}$

When a state wishes to become party to a treaty, but it objects to one or more provisions of the treaty (not wanting to be bound by them), it may register a reservation, the subject of Articles $19-15$. Reservations are the way the State asks to be excused from the obligation to comply with the undesired clauses. Normally, reservations are

\footnotetext{
${ }^{115}$ The Principle of consent is also formulated as the rule pacta tertiis nec nocent nec prosunt.

${ }^{116}$ Kaczorowska, Public International Law (2010), 91.

${ }^{117}$ Nuclear Tests Case (Australia v France), para. 46 (ICJ 1969) “...one of the basic principles governing the creation and performance of a larger obligation, whatever their source, is the principle of good faith."
} 
valid except in cases when: 1 ) they are explicitly prohibited by the treaty; 2) the particular clause prohibits a reservation or; 3) when the reservation is deemed incompatible with the objects and purposes of the treaty.

\section{Customary law}

The second primary source of international law cited by ICJ Article 38(1)(b) is international custom. International custom, or customary law, is defined by Article 38(1)(b) as "evidence of a general practice accepted as law." The most common legal view regarding the formation of customs (reflected on the ICJ ruling of the ICJ in The North Sea Continental Shelf Cases $(1968)^{118}$ expresses that customs are created by the combination of two elements: an objective element consisting of a relatively uniform and constant state practice (usus); and a psychological element composed of "the conviction that such practice reflects, or amounts to, law (opinio juris) or is required by social, economic, or political exigencies (opinio necessitatis)."119

An interesting feature of customary law is that:

the main feature of customs is that normally it is not a deliberate lawmaking process. In the case of customs, States, when participating in the norm-setting process, do not act for the primary purpose of laying down international rules. Their main concern is to safeguard some economic, social or political interests. The gradual birth of a new international rule is the side effect of States' conduct in international relations. ${ }^{120}$

\footnotetext{
${ }^{118}$ The North Sea Continental Shelf Cases (Federal Republic of Germany $v$ Netherlands) (ICJ 1968), http://www.icj-cij.org/docket/index.php?sum=295\&p1=3\&p2=3\&case=52\&p3=5.

${ }^{119}$ Cassese, Antonio. International Law (Oxford: Oxford University Press 2005), 156.

${ }^{120}$ Cassese, International Law, 156.
} 
Even though international treaties and international customary law are both considered primary sources of international law because they express primary rules (what is permitted and what is prohibited), a central difference between them is that while “...customary rules are normally binding upon all members of the world community (or of a regional group of States, in the case or regional customs), treaties only bind those States that ratify or adhere to them." ${ }^{, 121}$ Legal obligations deriving from international customary law therefore applies nearly to all states indeed, with a few exceptions. ${ }^{122}$ Although international customary law can be commonly found codified in international treaties, customs do not need to be written in any international document for them to be obligatory. The authority of customary law emanates from being reflective of the continual behavior of states throughout history and the shared belief that such acts were so important they needed to become mandatory to all states. ${ }^{123}$ The obligations created by treaties and customary law are equally authoritative : "rules created using bilateral or multilateral treaties were not stronger than, or superior to, customary or general rules, and vice-versa. Both sets of rule possessed equal rank and status." ${ }^{124}$

When legal rules originating from different sources conflict, International Law applies a set of principles to determine which is to be applied: "a later law repeals an earlier one (lex posterior derogat priori); a later law, general in character, does not

\footnotetext{
${ }^{121}$ Cassese, International Law, 157.

${ }^{122}$ For example, not all State need to abide by customary law, when the law is not general or when the State has objected to the formation of the rule (persistent objector rule). For more information, see Kaczorowska, Public International Law, 27 and 41.

${ }^{123}$ Kaczorowska, Public International Law, 35.

${ }^{124}$ Cassese, International Law, 154.
} 
derogate from a previous one which is special in character (lex posterior generalis non derogat priori speciali); a special law prevails over a general law or lex speciali derogat generali." 125

Jus cogens

Jus cogens rules or peremptory norms are "international customary rules of the highest status of law"; they express moral absolutes from which no State can claim an exemption. ${ }^{126}$ "Jus cogens are hierarchically superior to all the other rules of international law, and as such, the three general principles governing the relationship between international regulations (consent, pacta sunt servanda, good faith) do not apply to them." 127

"States may not derogate from peremptory norms through treaties or customary rules that do not have the special legal force of such norms. ${ }^{, 128}$ As defined by Article 53 of the Vienna Convention on the Law of Treaties: "a peremptory norm of general international law is a norm accepted and recognized by the international community of states as a whole as a norm from which no derogation is permitted and which can be modified only by a subsequent norm of general international law having the same character."

\footnotetext{
${ }^{125}$ Cassese, International Law, 154.

${ }^{126}$ Kaczorowska, Public International Law, 48.

${ }^{127}$ Cassese, International Law, 155.

${ }^{128}$ Cassese, International Law, 155.
} 
International society has not yet agreed upon a definitive list of jus cogens rules. ${ }^{129}$ Most states and international courts have recognized that grave violations of International Humanitarian Law and International Human Rights Law such as war crimes, genocide, torture, crimes against humanity, for example, are considered violations of jus cogens rules.

Jus cogens, as peremptory obligations, extend to individuals. If and when infringed, a duty to prosecute violations of jus cogens rules is a placed upon states, yet owed to the international society as a whole. In other words, the obligation to prosecute is an obligation erga omnes (the obligations falls over the international community as a whole); any state that holds in custody someone accused of violating a rule of jus cogens status may prosecute, with no need of a national or territorial link to the case. Indeed, under the principle aut dedere, aut judicare that State must either prosecute them in good faith, or it must extradite them to a state that is willing and able to do so. ${ }^{130}$

\section{Secondary sources of International Law}

The secondary or subsidiary sources of international law are used to fill gaps when there are no primary sources of law guiding a particular case. Despite not generating binding commitments themselves, these sources serve as guidance for the implementation and interpretation of existing treaties and customary law, and may also constitute evidence of law, thus being essential in any legal analysis.

\footnotetext{
${ }^{129}$ Kaczorowska, Public International Law, 50.

${ }^{130}$ Cassese, “Aut Dedere Aut Judicare”, The Oxford Companion to International Criminal Justice, 253 254.
} 
Some examples of secondary sources of law are general principles of international law, judicial decisions of international or national courts applying international law, and the writings of renowned publicists and jurists.

\section{General principles of International Law}

When a court is unable to find a treaty provision relevant to a dispute, or customary law, and to avoid a finding of non liquet (when the law in that particular case is not clear) courts may apply general principles of international law. ${ }^{131}$ General principles of international law can either be inferred from municipal laws or deduced from the nature of the international community. ${ }^{132}$ There is no established consensus between jurists whether it is one or another. "The case law of the ICJ shows that the Court has had recourse to both." 133

\section{Judicial decisions}

Previous decisions, whether coming from the same court or another do not carry the same obligatory character in international law that they do in Common Law systems. "Article 59 of the Statute of the Court provides that: the decision of the Court has no binding force except between the parties and in respect of that particular case" and this because not all states have the same international obligations. ${ }^{134}$ States' international obligations are distinct, as they reflect which treaties a particular state has voluntarily engaged to follow. The international courts, for example, when asked to adjudicate a case, it does so by

\footnotetext{
${ }^{131}$ Kaczorowska, Public International Law, 50.

${ }^{132}$ Kaczorowska, Public International Law, 53.

${ }^{133}$ Kaczorowska, Public International Law, 53.

${ }^{134}$ Article 59 of the Statute of the International Court of Justice, http://www.icjcij.org/documents/?p1=4\&p2=2\#CHAPTER_III.
} 
taking into consideration which international obligations each State holds and how these vary from one state to another. Since there is no precedent doctrine in international law (stare decisis) international court and tribunal cases do not necessarily make law. The non-precedent doctrine is challenged in international criminal law where individuals do in fact follow the same international legal obligations.

The writings of publicists and the teachings of the most highly qualified jurists of the various nations

Examples are the International Law Commission, the American Law Institute, L'Institut de Droit International, the Hague Academy of International Law and the International Commission of the Red Cross (ICRC), ${ }^{135}$ these sources function as subsidiary, meaning, the writings of experts do not constitute law per se, but they provide essential guidance in properly applying and interpreting the existing laws. The written work of these groups can be consulted, or their members can be called to provide expert testimony in a court's ruling.

The present chapter has served as an introductory mapping of the main sources of law recognized by International Law (as set by Article 38 of the International Court of Justice). The sources are to be considered the main tools of analysis for the current work. In latter chapters, I will explain how international courts utilize the sources here listed.

\footnotetext{
${ }^{135}$ Article 38 (1) (d) of the Statute of the International Court of Justice.
} 
Chapter 4: Universal conceptions of childhood and the international regime of children's rights

Childhood is universally described as a developmental phase between birth and adulthood, consisting of a period during which the individual still has limited capacities and should be protected and cared for by society and the law.

Universal conceptions of childhood delivered by the human sciences are the common ground that inform and influence how governments recognize and treat children under the law. In international law, the legal regime regarding the status of minors that was developed by states and international organizations is not in any way different; children are framed as entitled to special protections. The Convention on the Rights of the Child, nonetheless, marks an important starting point towards change in the discourse of child competence.

\section{Childhood}

Childhood is generally understood as the phase between birth/infancy and adulthood. The exact limits of where the period of childhood starts and where it ends, as well as what it means to be a child, is a source of controversy and debate. One possible reason for the lack of consensus is that the concept of childhood is culturally defined, not fixed, and in constant negotiation. "Society's notions of childhood are intrinsically linked to the way [children] are educated, the way they are dressed, the age at which they are expected to work and fend for themselves, and through common notions of responsibility 
of parents and the state towards them." ${ }^{136}$ Besides being culturally demarcated, the definition of childhood is also an adult-centric endeavor. Specialized literature generally understands childhood in negative terms: that is, a child is someone who lacks adult capacities and competencies. ${ }^{137}$ 'Not yet an adult' is the common adult-centric conceptualizations of what it is to be a child, despite seriously failing to characterize what being a child is.

Legal policies relating to children's capacities are also mostly influenced by the mainstream conception that the phase of childhood is made of a series of "separate states a child goes through until adulthood" which entitles them to protection due to their vulnerability and immaturity. ${ }^{138}$

For us, childhood is a stage or state of incompetence relative to adulthood. The ideal adult is equipped with certain cognitive capacities, is rational, physically independent and autonomous, has a sense of identity, and is conscious of her beliefs and desires, and thus able to make informed free choices for which she can be held personally responsible. It is on account of these dispositions that an adult is thought able to work for her living, be accountable at law for her actions, make sexual choices and help to choose the government of the community. It is because the child lacks these adult dispositions that he may not participate in this adult world. ${ }^{139}$

An international human rights regime has been established with the goal of guaranteeing what is understood as an appropriate minimum level of protection to all children, despite its origins, color, nationality, sex and gender.

\footnotetext{
${ }^{136}$ Fionda, Julia, ed. Legal Concepts of Childhood (Hart Publishing, 2001), 3.

${ }^{137}$ Archard, David and Colin M. Macleod, The Moral and Political Status of Children. Oxford Scholarship Online. 2002, 13.

${ }^{138}$ Archard, David, Children, Rights and Childhood (London: Routledge, 2004), 40.

139 Archard, Children, Rights and Childhood, 39.
} 
The International children's rights regime

Children's rights are a part of human rights; they are human rights specifically addressed to children. International Human Rights Law's point of departure is the underlying assumption that every human being is entitled to something, by simple virtue of being a human being. Human rights are universal (belonging 'to each of us regardless of ethnicity, race, gender, sexuality, age, religion, political conviction, or type of government') and subjective (being 'the properties of individual subjects'). Human rights are laid down in various international and domestic agreements, such as the United Nations Universal Declaration of Human Rights, multilateral and regional treaties, as well as, nationals constitutions around the world. ${ }^{140}$

An international regime of children rights first arose from the perception that, in times of war, children are among those who suffer the most. As a direct effect of children's involvement and suffering during the first World War, the League of Nations in 1924 promulgated the Geneva Declaration of the Rights of the Child, considered the first international document to declare legal standards for the treatment of children at the international level. The Geneva Declaration spelled out five provisions. ${ }^{141}$ These provisions were formulated not necessarily “...in terms of rights of children but, rather,

\footnotetext{
${ }^{140}$ Ang, Fiona, A Commentary on the United Nations Convention on the Rights of the Child: Article 38: Children in Armed Conflicts (Leiden: Martinus Nijhoff Publishers, 2005), 9.

${ }^{141}$ The five rules present in the Declaration of the Rights of the Child (1924) were: 1) The child must be given the means requisite for its normal development, both materially and spiritually; 2) The child that is hungry must be fed; the child that is sick must be nursed; the child that is backward must be helped; the delinquent child must be reclaimed; and the orphan and the waif must be sheltered and succored; 3 ) The child must be the first to receive relief in times of distress; 4) The child must be put in a position to earn a livelihood, and must be protected against every form of exploitation; 5) The child must be brought up in the consciousness that its talents must be devoted to the service of fellow men.
} 
as duties declared and accepted by men and women of all nations." ${ }^{142}$ In the text, children were entitled to protection rights exclusively as a result of the adults' exercising their obligation not to violate them. In other words, children's rights were, therefore, framed simply as a responsibility of the adults, who held an obligation to refrain from violating their protection rights in times of conflict and in times of peace. ${ }^{143}$ Interestingly, even though the beneficiaries of the declaration were 'children', no definition of child was presented.

The Declaration was the first platform for children's rights at the international level and it marked an important landmark even though it was not legally binding. For the very first time “...countries of different cultures recognized universal principles and necessities of the Rights of the Child." 144

The Geneva Declaration was followed by the UN Declaration of the Rights of the Child (1959). This declaration was adopted “... unanimously by all 78 Member States of the United Nations General Assembly in Resolution 1386 (XIV), ${ }^{145}$ and it marked the first major international consensus on the fundamental principles of children's rights." Ten principles were set. The General Assembly called upon “...parents, upon men and women as individuals, and upon voluntary organizations, local authorities and national

\footnotetext{
${ }^{142}$ Detrick, Sharon, J. E. Doek, and Nigel Cantwell. The United Nations Convention on the Rights of the Child: A Guide to the "Travaux Préparatoires" (Dordrecht: M. Nijhoff Publishers, 1992), 13.

${ }^{143}$ Detrick, The United Nations Convention on the Rights of the Child: A Guide to the "Travaux Préparatoires," 13.

${ }^{144}$ Humanium, "Standard References on Child Rights," http:/www.humanium.org/en/childrens-rightshistory/references-on-child-rights/.

${ }^{145}$ United Nation General Assembly Resolution 1386 (XIV).

${ }^{146}$ Humanium, "Declaration of the Rights of the Child, 1959," http://www.humanium.org/en/childrensrights-history/references-on-child-rights/declaration-rights-child/.
} 
Governments to recognize these rights and strive for their observance by legislative and other measures progressively taken by the following principles." ${ }^{147}$ Again, no definition of children was given.

Eleven years before the 1959 UN Declaration of the Rights of the Child, in 1948, the UN General Assembly took gradual steps toward establishing a universal platform for human rights in general, children included. Article Two of the UDHR established that:

everyone is entitled to all the rights and freedoms set forth in this Declaration [Universal Declaration of Human Rights] without distinction of any kind, such as race, color, sex, language, religion, political or another opinion, national or social origin, property, birth or another status. Furthermore, no distinction shall be made by the political, jurisdictional or international status of the country or territory to which a person belongs, whether it be independent, trust, non-self-governing or under any other limitation of sovereignty.

Although discrimination by age was not mentioned, "in the text, children (as well as, mothers to be) were recognized as a vulnerable social group, thus entitled to 'special help and assistance' (Article 25 (2)). It was the understanding that the rights proclaimed in the $U D H R$, would "apply equally to children and adults" which explained why the text did not attribute a different status to children, nor treated them as a detached social group with specific needs. ${ }^{148}$

The UDHR (sourced by a General Assembly Resolution) was not created as a legally binding instrument; therefore, in order to translate the newly internationally delineated human rights into more precise and binding terms, aiming at increasing level

\footnotetext{
${ }^{147}$ UN Declaration of the Rights of the Child Proclaimed by General Assembly Resolution 1386(XIV) of 20 November 1959), (http://www.unicef.org/malaysia/1959-Declaration-of-the-Rights-of-the-Child.pdf.

${ }^{148}$ UNICEF, "Understanding the CRC," (updated May 19, 2014): https://www.unicef.org/crc/index_understanding.html.
} 
of compliance with its provisions, the United Nations promulgated two fundamental international human treaties - the 1966 International Covenant on Civil and Political Rights (ICCPR) and the 1966 International Covenant on Economic, Social and Cultural Rights (ICESCR). Both treaties contained provisions related to rights delineated in the UDHR, such as the right to the protection against economic exploitation, the right to be educated and the right to healthcare (ICESCR) and the right to have a name and a nationality (ICCPR) ${ }^{149}$ However, this time, the provisions were contained in international treaties that were binding upon State parties.

Since then, most of the articles contained in the UDHR have been recognized as customary law, some acquiring the status of jus cogens rules, thus holding obligatory status for all states and people. ${ }^{150}$ As argued by Detrick, both covenants, the ICCPR and the ICESCR contained provisions applying to "the child," "children," "young persons," or "juvenile persons," however, they do not provide definitions of these terms. ${ }^{151}$ The author goes on to explain that the UN Human Rights Committee provided a comment on Article 24 of the ICCPR, stating, "the covenant does not indicate the age at which he [the minor] attains his majority... [because] this is to be determined by each State party in light of the relevant social and cultural conditions." 152

\footnotetext{
${ }^{149}$ Humanium, "Children's Rights History: Historical overview of the Children's rights evolution," http://www.humanium.org/en/childrens-rights-history/

150 As early as 1966, the International Law Commission had already acknowledged the intrinsic relationship between jus cogen rules and human rights, see Yearbook of the International Law Commission, ii, at 248, 1966, UN Doc A/CN.4/SER.A/1966/Add. 1.
}

151 Detrick, Sharon, A commentary on the United Nations Convention on the Rights of the Child, 1999, 52. 152 Detrick, Sharon, A commentary on the United Nations Convention on the Rights of the Child, 1999, 52 and Human Rights Committee, "General Comment 17," (Thirty-fifth session, 1989). 
The next step toward building a greater child protection legal apparatus came from the International Labor Organization (ILO) in 1973. The ILO established - in the Convention concerning Minimum Age for Admission to Employment - the minimum age of fifteen for employment. This age limit reflected the age of completion of compulsory schooling (Article 2.3). The convention also set the minimum age for employment or work considered dangerous or possibly of jeopardizing one's health, safety or morals to no less than 18 years, which includes military work (Article 3.1$).{ }^{153}$ The 1973 Convention also encourages states to effectively abolish child labor below the stipulated minimum age.

In 1979, in light of the United Nations' declaration of the International Year of the Child, the Polish delegation proposed developing a revised international charter addressed specifically to children which would carry mandatory status. Poland argument was that it was time for a change: “....almost twenty years after the proclamation of the principles of the UN Declaration of 1959 it was time to take further and more consistent steps by adopting an internationally binding instrument in the form of a convention." 154 Poland's proposal led to ten years of work and the creation and adoption of the 1989 Convention on the Rights of the Child (CRC).

\footnotetext{
${ }^{153}$ ILO, C138 - Minimum Age Convention, 1973 (No. 138)," http://www.ilo.org/dyn/normlex/en/f?p=NORMLEXPUB:12100:0::NO::P12100 INSTRUMENT ID:3122 83.

${ }^{154}$ Detrick, Sharon, A Commentary on the United Nations Convention on the Rights of the Child, 1999, 15.
} 


\section{The CRC}

The Convention on the Rights of the Child (CRC) is the most important and "the most widely ratified treaty in history" - with the United States being the only state failing to engage before full worldwide ratification. ${ }^{155}$ Approved by the UN General Assembly, it entered into force in 1989 , and it marked the $30^{\text {th }}$ anniversary of the UN Declaration of the Rights of the Child. The Convention on the Rights of the Child (CRC) of 1989 is the cornerstone of children's rights in the world, detailing the rights to which children are entitled both as people and because of their special status.

Because it is so widely accepted, most academics, jurists, and international organizations treat the $\mathrm{CRC}$ as having attained universal ratification. UNICEF has even argued that "the ratification of a treaty by nearly all the States... is strong evidence that it has become customary international law."156

State parties to the CRC are obligated to make the "appropriate legislative, policy, administrative, and other measures for the implementation of the rights contained therein...ensuring, by all appropriate means, that the provisions are given legal effect in the States Parties' domestic legal systems."157

The Convention was the product of ten years of negotiation, and was received as the realization of consistent steps towards assuring that all children of the world were

\footnotetext{
${ }^{155}$ Cipriani, Don. Children's Rights and the Minimum Age of Criminal Responsibility: A Global Perspective (Farnham, Surrey, England: Ashgate Publishers, 2009), 12.

${ }^{156}$ UNICEF, "The Convention on the Rights of the Child- Fifteen Years Later Report: The Caribbean,":https://www.unicef.org/lac/cdn 15 anos ingles full(2).pdf).

${ }^{157}$ Baimu, Evarist. "International Protection of Children," in Max Plank Encyclopedia of Public International Law (Oxford Public International Law, July 2009, Updated in April, 2013). http://opil.ouplaw.com/view/10.1093/law:epil/9780199231690/law-9780199231690e904?rskey=kNAAma\&result=1\&prd=EPIL.
} 
recognized as bearers of rights, and that, as a result, they were entitled to the necessary protections to ensure the enjoyment of a happy, safe and healthy life. The message set forth was that children's rights were were recognized as holding the same rights as adults, interconnected and of equal importance. ${ }^{158}$

The $\mathrm{CRC}$ also provided an innovative approach to human rights, marking a departure from earlier instruments and traditional notions of child welfare by being the first international human rights treaty to contain a comprehensive set of universally recognized norms asserting the complementarity and interdependence of human rights: civil and political, economic, social and cultural. The Convention also set a new vision of the child, embodying a consensus regarding the empowerment and protection of children. ${ }^{159}$ The goal was "changing the way children are viewed and treated -i.e., as human beings with a distinct set of rights instead of as passive objects of care and charity." 160

Some parts of the CRC are essential to this dissertation. Article 1, for example, provides a definition of a child: "for the purpose of the convention a child would mean every human being below the age of eighteen years unless, under the law applicable to the child, majority is attained earlier." ${ }^{\prime 161}$ The CRC is the first international agreement to offer a definition for children. "The CRC's drafters decided to ... set the upper age limit

\footnotetext{
${ }^{158}$ UNICEF, “Understanding the CRC”, http://www.unicef.org/crc/index understanding.html.

${ }^{159}$ Fottrell, Deirdre, Revisiting Children's Rights: 10 Years of the UN Convention on the Rights of the Child (The Hague: Kluwer Law International, 2000), VII.

${ }^{160}$ UNICEF, "Convention on the Rights of the Child”, http://www.unicef.org/crc/.

${ }^{161}$ The definition was solely based on age criteria of age, and not in any other more subjective or cultural indicator of maturity.
} 
for eighteen years...to maximize the protections offered by the CRC and to ensure that the rights set forth therein would uniformly apply to as large an age group as possible."162 Another legal innovation was the institutionalization of the idea that children were bearers of rights as well. Children were seen as entitled to participation / liberty rights similarly to adults. Examples of such rights are: respect for the views of the child, freedom of expression, freedom of association, rights to privacy, access to information as expressed in Articles $4^{163}, 12^{164}, 13^{165}, 14^{166}, 15^{167}, 16^{168}, 17^{169}$. These rights, ultimately

${ }^{162}$ Detrick, Sharon, A commentary on the United Nations Convention on the Rights of the Child, 1999, 52.

${ }^{163}$ Article 4 (Protection of rights): Governments have a responsibility to take all available measures to make sure children's rights are respected, protected and fulfilled. When countries ratify the Convention, they agree to review their laws relating to children, which involves assessing their social services, legal, health and educational systems, as well as levels of funding for these services. Governments are then obliged to take all necessary steps to ensure that the minimum standards set by the Convention in these areas are being met. They must help families protect children's rights and create an environment where they can grow and reach their potential. In some instances, this may involve changing existing laws or creating new ones. Such legislative changes are not imposed but come about through the same process by which any law is created or reformed within a country. Article 41 of the Convention points out the when a country already has higher legal standards than those seen in the Convention, the stricter standards always prevail.

${ }^{164}$ Article 12 (Respect for the views of the child): When adults are making decisions that affect children, children have the right to say what they think should happen and have their opinions taken into account.

${ }^{165}$ Article 13 (Freedom of expression): Children have the right to get and share information, as long as the information is not damaging to them or others. In exercising the right to freedom of expression, children have the responsibility to also respect the rights, freedoms, and reputations of others. The freedom of expression includes the right to share information in any way they choose, including by talking, drawing or writing.

${ }^{166}$ Article 14 (Freedom of thought, conscience, and religion): Children have the right to think and believe what they want and to practice their religion, as long as they are not stopping other people from enjoying their rights. Parents should help guide their children in these matters. The Convention respects the rights and duties of parents in providing religious and moral guidance to their children. Religious groups around the world have expressed support for the Convention, which indicates that it in no way prevents parents from bringing their children up within a religious tradition. At the same time, the Convention recognizes that as children mature and can form their views, some may question certain religious practices or cultural traditions. The Convention supports children's right to examine their beliefs, but it also states that their right to express their beliefs implies respect for the rights and freedoms of others.

${ }^{167}$ Article 15 (Freedom of Association): Children have the right to meet and to join groups and organizations, as long as it does not stop other people from enjoying their rights. In exercising their rights, children have the responsibility to respect the rights, freedoms, and reputations of others. 
guaranteed by the state party, were framed as being equally important to protective rights and fundamental for the development of the child into a well-established, healthy and happy human being.

When applying the provisions set forth by the CRC, the Committee on the Right of the Child (CRC Committee) has indicated that states should be guided by four general principles -non-discrimination (Art. 2 CRC), the best interests of the child (Art. $3 \mathrm{CRC}$ ), the right to life, survival, and development (Art. 6 CRC; Life, Right to, International Protection; Development, Right to, International Protection), and evolving capacities of the child (Art. 5 and Art. 12, CRC). Arising from international treaty law, these principles are to be implemented by states within their domestic legislation. ${ }^{170}$

The principle 'evolving capacity of the child' is explicitly found in Articles 5 and 12 of the CRC as expressed in UNICEF's report Evolving Capacities of the Child (2005):

Article 5 of the Convention states that direction and guidance, provided by parents or others with responsibility for the child, must take account of the capacities of the child to exercise rights on his or her behalf. This principle has profound implications for the human rights of the child. It has been described as a new principle of interpretation in international law, recognizing that as children acquire enhanced competencies, accordingly, there is a reduced need for direction and a greater capacity to take responsibility for decisions affecting their lives. ${ }^{171}$

\footnotetext{
${ }^{168}$ Article 16 (Right to privacy): Children have a right to privacy. The law should protect them from attacks against their way of life, their good name, their families and their homes.

${ }^{169}$ Article 17 (Access to information; mass media): Children have the right to get information that is vital to their health and well-being. Governments should encourage mass media - radio, television, newspapers and Internet content sources - to provide information that children can understand and to not promote materials that could harm children. Mass media should particularly be encouraged to supply information in languages that minority and indigenous children can learn. Children should also have access to children's books.

${ }^{170}$ Baimu, "Children, International Protection,” 2013.

${ }^{171}$ Lansdown, Gerison. The evolving capacities of the child (Stockholm: Save the Children, 2005), 3.
} 
The goal of the drafters was to create a legal scenario in which "children's capacities can differ according to [their maturity level and] the nature of the rights to be exercised.

Children, therefore, require varying degrees of protection, participation, and opportunity for autonomy in different contexts and across different areas of decision-making."172

Article 12.1 expresses that "State Parties shall assure to the child who is capable of forming his or her own views the right to express those views freely in all matters affecting the child, the views of the child being given due weight in accordance with the age and maturity of the child;" in other words, the greater the age and capacity of the child, the more seriously their views should be considered. ${ }^{173}$

The Committee on the Rights of the Child has identified Article 12 as one of the central underlying principles of the Convention, demanding a fundamental shift in the conventional approach of casting children as passive recipients of adult protection to acknowledging them as active agents, entitled to participate in decisions that affect their lives. ${ }^{174}$

The second principle worth highlighting that sheds light on how the provisions of the Convention are to be interpreted, as determined by the Committee on the Rights of the Child, is the "best interest of the child." 175 Found mainly in Articles 5 and 18, this

\footnotetext{
${ }^{172}$ Lansdown, The evolving capacities of the child, 4.

${ }^{173}$ CRC/C/GC/12/, "Committee on the Rights of the Child -General Comment No. 12 (2009) The right of the child to be heard," http://www2.ohchr.org/english/bodies/crc/docs/AdvanceVersions/CRC-C-GC12.pdf.

${ }^{174}$ Lansdown, The evolving capacities of the child, 4.

${ }^{175}$ As stipulated by the United Nations Human Rights Office of the Commissioner, the Committee on the Rights of the Child "is the body of 18 Independent experts that monitors implementation of the Convention on the Rights of the Child by its State parties. It also monitors implementation of two Optional Protocols to the Convention, on involvement of children in armed conflict and on sale of children, child prostitution and
} 
principle identifies the child as the recipient of the protections and rights enshrined in the CRC. Article 5 once again stresses that the State must respect the rights and responsibilities of parents or other caregivers to provide "appropriate direction and guidance in the exercise by the child of their rights in a manner consistent with the evolving capacities of the child." In other words: "parental rights and responsibilities are not unbounded. By inserting the word 'appropriate,' Article 5 removes the possibility that parents to have carte blanche to provide, or fail to provide, whatever guidance and support they deem suitable."176

The chapter has provided an overview on the universalized conceptions of childhood which influence the fields of the human sciences, as well as policies related to the protection of the child in an adult-centric world. The establishment of the Convention of the Rights of the Child (1989) can be celebrated as a successful breakpoint from older views of passivity and incompetence attributed to children. By framing the child as bearer of rights (and not only recipient of protections), and by establishing provisions which focus on the evolving capacity and best interests of the child, the Convention has paved the ground for discussions of the autonomy, legal competence, and responsibility of children in the international legal system.

child pornography." ("Committee on the Rights of the Child", United Nations Human Rights Office of the Commissioner, http://www.ohchr.org/EN/HRBodies/CRC/Pages/CRCIndex.aspx).

${ }^{176}$ Lansdown, The evolving capacities of the child, xi. 
Chapter 5: Analysis of treaty and customary law on child recruitment and misperceptions arising from them

Chapter five invites the reader to embark on the legal mapping of the current international rights and legal protections awarded to the child in times of peace and in times of armed conflict. These protections are mainly found in International Humanitarian Law (IHL) and International Human Rights Law (IHRL) regimes. The first part of the chapter consists of a brief presentation of the main sources of these fields of international law. Treaties and customary law will be given priority in the analysis because they create obligations. Additional sources such as multilateral declarations will also be acknowledged, despite not usually generating obligation; their importance comes from the capacity to point to a possibly emerging different legal landscape. The first part of the chapter will also provide a brief presentation of the three international legal regimes which set out the protective measures granted to the child in both times of conflict and times of peace: International Humanitarian Law, International Human Rights Law, and International Criminal Law (ICL). The last one consisting on rules which impose punitive measures on those who violate the protective measures contained in IHL and IHRL. When analyzing the established law, the chapter will highlight the Minimum Age of Legal Recruitment (MALR) set at fifteen years of age by International Humanitarian Law at fifteen. 
Finally, the section will call attention to the politically misrepresentation of lex lata ${ }^{177}$ presented by the International Committee of the Red Cross and the UN Office of the Special Representative of the Secretary-General for Children and Armed Conflicts.

\section{The legal concept of child soldier}

The first attempt to codify the term child soldier occurred in the 1997 Cape Town "Symposium on the Prevention of Recruitment of Children into the Armed Forces and on Demobilization and Social Reintegration of Child Soldiers in Africa", which resulted in the adoption of the "Cape Town Principles and Best Practices." In this document, a child soldier was defined as "any person under 18 years of age (emphasis added) who is part of any kind of regular or irregular armed force or armed group in any capacity, including but not limited to cooks, porters, messengers and anyone accompanying such groups, other than family members. The definition includes girls recruited for sexual purposes and forced marriage. It does not, therefore, only refer to a child who is carrying or has carried arms." The symposium was an initiative jointly led by the NGO Working Group on the Convention on the Rights of the Child and UNICEF, and it aimed at "bring[ing] together experts and partners to develop strategies for preventing recruitment of children, in particular, for establishing 18 as the minimum age for recruitment and for demobilizing child soldiers and helping them reintegrate into society." "178

\footnotetext{
${ }^{177}$ Lex lata means: "the law that has been borne", or in other words, law as it is, as it exists ("lex lata" Oxford References, http://www.oxfordreference.com/view/10.1093/oi/authority.20110803100103408 (May 1, 2017).

178 "Cape Town Principles and Best Practices" (1997): http://www.unicef.org/emerg/files/Cape Town Principles(1).pdf).
} 
Ten years later, a second international convention took place that would further contribute to the definition of a child soldier. In 2007, as a result of the international conference 'Free Children from War' held in Paris, co-hosted by the government of France and UNICEF, two additional non-binding documents were added to the existing network of legal protection of children during armed conflict: the "Paris Commitments to Protect Children from Unlawful Recruitment or Use by Armed Forces or Armed Groups" and the "Paris Principles and Guidelines on Children Associated with Armed Forces or Armed Groups." The Paris Principles set an important landmark in the discussion of the concept of a child soldier in the international legal discourse. ${ }^{179}$ Intended to extend the Cape Town protections, the Paris Principles abandoned the more strict focus on child soldiers to instead consider a wider approach to protection that would focus on all children associated with armed groups and armed forces. The wider and more comprehensive approach proposed by the Paris Principles has been the trend followed by most current international legal discourse to honor the notion that war affects children in general, despite the fact that some may carry arms, while others do not.

Article 2.1 of the Paris Principles presents the definition for "children associated with armed forces and armed groups" as:

... any person below 18 years of age (emphasis added) who is or who has been recruited or used by an armed force or armed group in any capacity, including but not limited to children, boys and girls, used as fighters,

\footnotetext{
${ }^{179}$ The Paris Principles resulted from a cooperation between UNICEF, the European Commission's Humanitarian Aid Office, NGO's, representatives of international agencies and governments as explained in "Paris Conference "Free Children from War", UNICEF:

(http://www.unicef.org/media/media 38208.html).
} 
cooks, porters, messengers, spies or for sexual purposes. It does not only refer to a child who is taking or has taken a direct part in hostilities."180

Due to the fact that the concept extends to all children involved in armed groups and armed forces, it has been considered by a "very wide definition by some scholars."181 And although "the official nomenclature drifted away from child soldier as initially set out and defined in the Cape Town Principles, into... the somewhat tongue-trying children associated with armed forces and armed groups...[in practical terms] both still share considerable textual overlaps regarding the actual persons they protect." ${ }^{\text {"182 }}$ Despite the nomenclature change, the term 'child soldier' is still mostly applied in the media and in specialized literature to identify those underage individuals who have been recruited to join an armed group or the armed forces.

Definition of child soldier follows age criteria: fifteen or eighteen years old?

Both the Cape Town and Paris conferences defined child soldiers as anyone below the age of eighteen "who is part of any regular or irregular armed force or armed group in any capacity" or "who has been recruited or used by an armed force or armed group in any capacity." This being, eighteen years of age was the age selected to determine the line between legal and illegal recruitment of minors on both of these conferences.

\footnotetext{
${ }^{180}$ In Principle 2.4, the term "recruitment" refers to compulsory, forced and voluntary conscription or enlistment of children into any armed force or armed group." In Principle Article 2.2, the term "armed forces" refers to the armed forces of a State. And in Paris Principle 2.3, the term "armed groups" refers to groups distinct from armed forces as defined by Article 4 of the Optional Protocol to the Convention on the Rights of the Child on the involvement of children in armed conflict.

${ }^{181}$ Waschefort, Gus, International Law and Child Soldiers (Oxford, Portland: Hart Publishing Limited, 2014), 15.

${ }^{182}$ Drumbl, Reimagining Child Soldiers in International Law and Policy, 4.
} 
In international law, the definition of children, and thus, child soldiers follows age criteria: "international law relates to what constitutes a child simply regarding age;" "183, the Convention on the Rights of the Child defines a child generally as anyone below the age of eighteen, so logically, at least in International Human Rights Law, a child soldier would be characterized as a soldier under the age of eighteen. The provisions that regulate the recruitment of child soldiers are also based on age criteria, and not other more subjective criteria tied to localized maturity standards. ${ }^{184}$ Recall, however, that International Humanitarian Law, as set by the CRC and its Additional Protocols allows for the recruitment and use of children in armed conflicts starting at age fifteen, and that in the commentaries to the Additional Protocols, the drafters declared that they understood children to be individuals up to the age of fifteen. ${ }^{185}$ The logical conclusion to be drawn from this is that international law, and more importantly, Humanitarian Law allows the recruitment and use of children in armed conflicts starting at age fifteen despite the fact that anyone below eighteen may still be considered a child soldier.

Putting it differently, there is a still an amount of confusion in regards to what international law considers a child soldiers when it comes to legal age of recruitment. In the commentaries to Additional Protocols I and II (International Humanitarian Law) published by the ICRC, the drafters expressed the opinion that 'children' is understood as

\footnotetext{
${ }^{183}$ Freeland, "How International Law Deals with Child Soldiers," section III, 307-8.

${ }^{184}$ Freeland, "How International Law Deals with Child Soldiers," section III, 307-8.

185 "Commentary of 1987 to the Additional Protocol to the Geneva Convention (1977), "ICRC,: https://ihldatabases.icrc.org/applic/ihl/ihl.nsf/Comment.xsp?action=openDocument\&documentId=8E174BC1926F72 FAC12563CD00436C73
} 
individuals up to the age of fifteen. However, afterwards the CRC (International Human Rights Law) defines children as anyone below eighteen, which would lead us to conclude that Additional Protocols I and II as well as the CRC (Article 38) actually allow for the legal recruitment and use of individuals under eighteen which according to the stipulated age set by CRC and the definitions of child soldiers presented in both conferences on child soldiers would be considered child soldier.

The confusion is further explored by Waschefort (2015) in the passage below:

there are two ways in which to address this phenomenon [child soldiering]. First, one can argue that the law does not prohibit the enlistment of the child into the military, that child will not be deemed a child soldier. Or, alternatively, that the child soldier remains a child soldier, but that no legal norms were violated in recruitment or even using that child in military operations, where the relevant state has not subscribed to a legal obligation to the contrary. The United Kingdom, for example, has not subscribed to any legal norm that bars it from recruiting persons under sixteen years of age or older into its armed forces, and indeed the UK does recruit such persons. [As 2013, the UK became a party to the OPAC, and thus hold the obligation of not recruiting anyone below sixteen.] In contrast, Norway has subscribed to such international norms. If one were to favor an interpretation in terms of which concept of child soldier is the one which inherently denotes unlawfulness of the child's enlistment, conscription or use, it would mean that a sixteen-yearold child would be deemed to be a child soldier if she or he were in the Norwegian Armed Forced but would not be deemed a child soldier if she or he were in the British Armed Forces. ${ }^{186}$

Waschefort concludes by stating, "the term child soldier is thus broadly and legally imprecise... As a result, a child soldier in one country may not be a 'child soldier in another." 187

\footnotetext{
${ }^{186}$ Waschefort, International Law and Child Soldiers, 14.

${ }^{187}$ Waschefort, International Law and Child Soldiers, 14.
} 
The dubiety in the nomenclature highlighted by Waschefort relates to the gap between the minimum military age adopted by certain countries and the age of majority set at eighteen by the CRC. As established by national law, the minimum age of recruitment varies from one country to another; so, in one country, a person recruited at age sixteen may not be considered a child soldier according to national standards, while in another country where the minimum age of recruitment is eighteen, that sixteen-yearold child, if recruited, would be labeled as a child soldier. Waschefort is accurate when applying domestic standards to characterize whether the young recruit is considered a child soldier, however, the plurality of these domestic rules nonetheless increase the level of confusion.

How international law deals with the problem of child soldering

The international legal regimes aimed at protecting the child from early recruitment and use in armed conflicts is the subject of the present chapter. The next chapter delves into the other side of how international law enforces the protection against child soldiering by authorizing international and domestic courts to try those who are accused of recruiting and use children below the age of fifteen in armed conflicts.

Legal protections against the recruitment and use of children in armed conflicts

1. Additional Protocols to the Geneva Conventions (1977)

The first efforts to internationally prohibit children's direct involvement in armed conflicts (international and non-international) by placing obligations on states against the recruitment of young soldiers are found in Additional Protocols I and II to the Geneva Conventions (1977). 
Before the Additional Protocols, "there is no express regulation of the participation of children in armed conflicts in any of the four Geneva Conventions (the GCs).

“Additional Protocol I (AP I) and Additional Protocol II (AP II) to the 1949

Geneva Conventions... clearly set out the obligation under International Humanitarian Law of State parties to those Protocols, when engaged in armed conflict, to provide special protection to children of all ages caught up in the conflict as a protected class in and of themselves." ${ }^{, 188}$ More specifically, Additional Protocol I - regulating international armed conflicts - determines in Article 77.2 that:

The Parties to the conflict shall take all feasible measures in order that children who have not attained the age of fifteen years do not take a direct part in hostilities and, in particular, they shall refrain from recruiting them into their armed forces. In recruiting among those persons who have attained the age of fifteen years but who have not attained the age of eighteen years, the Parties to the conflict shall endeavor to give priority to those who are oldest.

Additional Protocol II - aimed at regulating non-international conflicts - creates a positive obligation for states and non-State parties alike to a conflict to assure that "children who have not attained the age of fifteen years shall neither be recruited in the armed forces or groups nor allowed to take part in hostilities" and " that children who have not attained the age of fifteen years shall remain applicable to them if they take a direct part in hostilities..."

The drafters of the Additional Protocols understood children to be a separate group, more dependent and vulnerable than their adult counterparts, and because their

\footnotetext{
${ }^{188}$ Grover, Child Soldier Victims of Genocidal Forcible Transfer Exonerating Child Soldiers Charged with Grave Conflict-related International Crimes, 10.

${ }^{189}$ Additional Protocol II, Article 4(3)(c).
} 
vulnerability intensifies during times of armed conflict, the Committee placed special protections directly on to children. These protections were additional to those offered generally to civilians not involved in the hostilities ('protected persons' according to International Humanitarian Law).

No definition or age limitation regarding who is to be regarded as 'children' was provided in the Additional Protocols. The omission of what constitutes 'children' was intentional; "the term 'child' does not have an accepted definition." 190 The ICRC commentaries explained that:

According to the Concise Oxford Dictionary, the term "child" means a young human being who has not reached the age of discretion, i.e., the age at which one is fit to manage one's affairs ( $7^{\text {th }}$ edition, 1982). The Oxford English Dictionary (1970) defines a child as a human being up to the age of puberty. The French Dictionary Robert indicates that it means a human being from birth up to the age of thirteen; this is followed by adolescence. The age of puberty varies, depending on climate, race and the individual. However, the limit of fifteen years of age, which is given many times in the fourth Convention and is also given in paragraphs 2 and 3 of this article, seems to provide a reasonable basis for a definition. Moreover, the article itself in paragraphs 2 and 5 uses the word "persons" in referring to a limit of eighteen years. This does not prevent the fact that some countries have adopted a lower or higher age than fifteen years, but there is no doubt that all human beings under fifteen should, within the meaning of the Fourth Convention and [p.900] this Protocol, be considered and treated like children. The age of fifteen most often corresponds to such development of the human faculties that extraordinary measures are no longer required to the same degree. However, some flexibility is appropriate, for there are individuals who remain children, both physically and mentally, after the age of fifteen. Furthermore, this age of fifteen has been adopted in other international instruments. Thus, for example, in a recommendation of 1965 relating to the minimum age for marriage (Resolution 2018 (XX)) the United Nations General Assembly requested

\footnotetext{
${ }^{190}$ ICRC Commentaries 3178-9.
} 
States to determine a minimum age for marriage and specified that that age should in no case be under fifteen years. ${ }^{191}$

As we can see in the Commentaries to the Additional Protocols of the CRC (1977), it was the opinion of the Committee and its predecessors that: 'children' is considered anyone up to the age of fifteen. The age of fifteen was chosen by the drafters to be the minimum age for the legal recruitment and use of children by armed forces and armed groups in international armed conflicts (found in Additional Protocol I) and noninternational armed conflicts (found in Additional Protocol II).

\section{Article 38 of the Convention on the Rights of the Child}

Article 38 of the CRC, despite being contained within an International Human Rights Law convention, is applicable in International Humanitarian Law because it addresses the recruitment and use of children during armed conflicts, and thus, interestingly brings two branches of IL (International Humanitarian Law and International Human Rights Law) more closely together. ${ }^{192}$ This proximity explicitly illustrates how the drafters believed that protecting children in times of conflict closely was aligned with the need of protecting children also in times of peace.

\footnotetext{
${ }^{191}$ Protocol Additional to the Geneva Conventions of 12 August 1949, and relating to the Protection of Victims of International Armed Conflicts (Protocol I), 8 June 1977. International Committee of the Red Cross, Protocol Additional to the Geneva Conventions of 12 August 1949, and relating to the Protection of Victims of International Armed Conflicts (Protocol I), 8 June 1977. Commentary of 1987, Protection of Children: https://ihl

databases.icrc.org/applic/ihl/ihl.nsf/Comment.xsp?action=openDocument\&documentId=8E174BC1926F72 FAC12563CD00436C73.

${ }^{192}$ Ang, Article 38: Children in Armed Conflicts, 3.
} 
Article 38 is “...structured according to a typical International Humanitarian Law scheme: its first paragraph contains a general provision on the applicability of International Humanitarian Law, the second and third paragraph deal with the protection of children from participation in hostilities or recruitment in the armed forces, and the fourth paragraph reminds the states Parties to protect the civilian population. Article 38, as a whole, apparently covers International Humanitarian Law substance, which is reinforced by its explicit references to International Humanitarian Law and the terminology ('hostilities,' 'recruiting,' 'civilian population', ... ) used... Thus, Article 38 of the CRC should be interpreted in line within International Humanitarian Law." ${ }^{193}$ As explained by Ang: "Article 38 of the CRC has a hybrid character. Materially speaking, Article 38 of the CRC is clearly an International Humanitarian Law provision yet within human rights instrument." ${ }^{194}$ Article 38 of the CRC establishes that: "Governments must do everything they can to protect and care for children affected by war. Children under fifteen should not be forced or recruited to take part in a war or join the armed forces." ${ }^{.195}$ The Article reaffirms the need for states "to respect and to ensure respect for rules of international humanitarian law applicable to them in armed conflicts which are relevant to the child."

The rules of International Humanitarian Law applicable specifically to the child is found in the Additional Protocols of the Geneva Convention I and II as discussed earlier.

\footnotetext{
${ }^{193}$ Ang, Article 38: Children in Armed Conflicts, 13.

${ }^{194}$ Ang, Article 38: Children in Armed Conflicts, 9.

${ }^{195}$ UNICEF, "Fact Sheet: A summary of the rights under the Convention on the Rights of the Child," http://www.unicef.org/crc/files/Rights overview.pdf.
} 
There is no consensus regarding whether these protocols have achieved customary law status, thus being considered obligatory only to states parties. All three conventions, the Additional Protocols I and II, and the CRC allow for the recruitment and use of children fifteen and above by armed forces and armed groups.

In terms of setting legal prohibitions against child recruitment, the $\mathrm{CRC}-$ as we have seen previously - fails to completely ban the deployment of persons under eighteen to hostilities, only requesting that states "take all feasible measures [weak obligation] to ensure that persons who have not attained the age of fifteen years do not take a direct part in hostilities." (Article 38.2) The obligation set on states is to "refrain from recruiting any person who has not attained the age of fifteen years into their armed forces." However, this does allow states to recruit children above the age of fifteen with the requirement that states are to prioritize the older children.

Another major downfall of the $\mathrm{CRC}$ is that it does not address, at least not directly, non-state armed groups. The CRC does not impose obligations upon armed groups regarding recruitment of juveniles; however, it does place a rather weak obligation upon states to "ensure that persons who have not attained the age of fifteen years do not take a direct part in hostilities" (Art. 38.2), which would include the criminalization of armed groups who recruit and use children under the age of fifteen.

\section{The OPAC}

The Optional Protocol to the Convention on the Rights of the Child on the Involvement of Children in Armed Conflict (OPAC), established in 2000 complements the 
$\mathrm{CRC}$ and offers wider and stronger protective measures against the recruitment and use of children (individuals under eighteen) in conflicts. ${ }^{196}$

In the case of the the Optional Protocol to the Convention on the Rights of the Child on the Involvement of Children in Armed Conflict, the protocol "is an effort to strengthen implementation of the Convention and increase the protection of children during armed conflicts. " ${ }^{\prime 197}$ Additional protections offered by the protocol include raising the age of conscription to eighteen; prohibiting states from deploying persons under eighteen to fight in direct hostilities. Another important innovation is that the protocol differently than the CRC, addresses armed forces and armed groups, which would theoretically widen the scope of protection of children involved in armed conflicts. ${ }^{198}$ The OPAC also raises the minimum age for voluntary enlistment to sixteen, instead of fifteen as set by the Additional Protocols I, II and the CRC. Still, the Optional Protocol has been seen as an advance upon the Convention on the Rights of the Child regarding addressing and redressing the "loose" provisions of minimum age of conscription, deployment, and use of children by armed groups. ${ }^{199}$

In despite of the apparent progress, the Protocol sets a weak obligation against the recruitment and use of those below the age of eighteen by armed groups and armed

\footnotetext{
196 Optional Protocols often complement human rights treaty by "providing for procedures with regard to the treaty or address a substantive area related to the treaty." "What is an Optional Protocol?", UN Women,

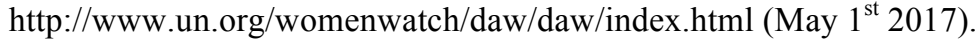

${ }^{197}$ UNICEF, "Optional Protocol on the involvement of children in armed conflict," https://www.unicef.org/crc/index 30203.html (May 1, 2017).

${ }^{198}$ UNICEF, "Fact Sheet: A summary of the rights under the Convention on the Rights of the Child: http://www.unicef.org/crc/files/Rights overview.pdf.

${ }^{199}$ Vanderwiele, Tiny, A Commentary on the United Nations Convention on the Rights of the Child Optional Protocol: The Involvement of Children in Armed Conflicts (Leiden: Martinus Nijhoff Publishers, 2006), 19.
} 
forces. Article 1 urges states to take "all feasible measures to ensure that members of their armed forces who have not attained the age of eighteen do not take direct part in hostilities" (Article 1). 'All feasible measure' is considered by many commentators as a fragile, and thus an inadequate means of protection, reflecting an obligation of means and not of result. ${ }^{200}$ This effectively translates to: states are to comply only if possible. The outbreak of a war and the need for manpower can be (and have traditionally been used as) a military necessity, and thus a viable justification for derogating from the provision to be fulfilled. For example, as argued by Child Soldier International:

The USA along with countries such as Australia and the United Kingdom also restrict protection for children if the withdrawal of under-18s would adversely affect the success of a military operation. The USA defines "feasible measures" as only those measures which are "practical or practically possible, taking into account all the circumstances ruling at the time, including humanitarian and military considerations." In the United Kingdom, deployment of members of the armed forces who have not yet reached 18 years is permitted where there is a genuine military need, the situation is urgent, it is otherwise not practicable to withdraw minors before deployment, or it would undermine the operational effectiveness of their ship or unit. In Australia "feasible measures" are required only to the maximum extent possible, and where it will not adversely impact the conduct of operations. ${ }^{201}$

A definite move forwards is that the OPAC completely bans the recruitment and use of individual below age eighteen by armed groups. Article 4.1 states that: "Armed groups that are distinct from the armed forces of a State should not, under any circumstances, recruit or use in hostilities persons under the age of 18 years."

\footnotetext{
${ }^{200}$ Vandewiele, A Commentary on the United Nations Convention on the Rights of the Child Optional Protocol: The Involvement of Children in Armed Conflicts, 26.

201 “Louder than Words Report," Child Soldiers International (2012), 47.
} 
In sum, the OPAC rules out the possibility of an armed group legally recruiting and using individuals below the age of eighteen in hostilities, yet, the same level of prohibition does not apply to governmental armed forces which can still recruit under eighteens, if the recruitment is allowed by domestic law and follows the established safe measurements established by the treaty. The OPAC makes states responsible for prohibiting and to enforcing measures to prevent the recruitment and use of children below the stipulated age in hostilities.

On a last note, the convention still kept the definition of children provided by the CRC. As a result, the recruits below the age of eighteen who have enlisted voluntarily are still considered by the convention as children. Therefore, it is safe to affirm that the OPAC, as the previous conventions before, continues to allow the lawful recruitment of children; those under eighteen years to serve in the military. Another important characteristic of the Protocol is that it has not reached the status of customary law, being obligatory only to those states parties to the document.

5. ILO Convention 182 concerning the Prohibition and Immediate Action for the Elimination of the Worst Forms of Child Labor

The last international treaty that directly addresses the prohibition of children's involvement in military actions and armed conflicts is the International Labor Organization (ILO) Convention 182 concerning the Prohibition and Immediate Action for the Elimination of the Worst Forms of Child Labour (2012). "Under this treaty, forced or compulsory (but not voluntary) recruitment of children under the age of 18 for use in armed conflict are among the worst forms of child labor from which children must be 
protected." 202 The treaty establishes that each state party "shall take all necessary measures to ensure the effective implementation and enforcement of the provisions giving effect to this Convention including the provision and application of penal sanctions or, as appropriate, other sanctions" (Article 7.1) as well as "take effective and time-bound measures to (7.2.a) prevent the engagement of children in the worst forms of child labour" and (7.2.b) "provide the necessary and appropriate direct assistance for the removal of children from the worst forms of child labour and for their rehabilitation and social integration." Convention 182 is considered to use stronger language to prohibit recruitment and use of children by the military, yet, still only applies exclusively to state parties. In 2017, a total of 180 states were signatories to the ILO Convention 182.

If a state is party to any of the instruments discussed in this chapter, its armed forces can continue to recruit persons under eighteen (individuals still considered children under CRC) while still being fully in compliance with international law if enlistment is considered voluntary: "Some countries using and recruiting child soldiers do so without violating any international legal obligation." ${ }^{203}$ The fact that International Law still allows armed forces (not armed groups) to legally use persons under eighteen seems not to be regarded problematic, and, for the most part, not to be considered the crime of child soldering.

\footnotetext{
202 "Louder than Words Report," Child Soldiers International (2012), 17.

${ }^{203}$ Waschefort, International Law and Child Soldiers (Studies in International Law), 32.
} 
When a child is engaged directly in the armed conflict does he or she loses the status of protected persons? How do International Humanitarian Law and International Human Rights Law treat an active child soldier?

One conceivable way to answer to the above questions is to affirm that the protections required by International Humanitarian Law are meant to protect all of those not taking direct part in the hostilities as well as a special category of vulnerable persons such as children. So, children due to their vulnerability, involved in armed conflict, or not, are per excellence protected persons. ${ }^{204}$

Another way to look at the issue is arguing that International Humanitarian Law sets a limitation in relation to civilians who have engaged in the armed conflict, which can include children. Civilians who have 'picked up arms' are, in general, no longer deemed as protected persons under International Humanitarian Law; they have lost their status of protection, are now considered legitimate targets under the law of armed conflict because they have chosen to engage in the conflict.

Reinforcing the second perspective, Rene Provost argues that: "If a child is enrolled in the armed forces of a party to an international armed conflict, there seems to be no apparent basis in current international humanitarian law to characterize that child as anything other than as a combatant.." ${ }^{205}$ Conversely, if the recruitment is by an armed group, and the child is not taking part of the conflict directly, then he or she keeps the status of "protected persons" under International Humanitarian Law.

\footnotetext{
204 "Rule 135: Children affected by armed conflict are entitled to special respect and protection," ICRC Handbook of Customary IHL: https://ihl-databases.icrc.org/customaryihl/eng/docs/v1_cha_chapter39_rule135.

${ }^{205}$ Provost, René, "Targeting Child Soldiers": http://www.ejiltalk.org/targeting-child-soldiers/, para.5.
} 
Frederic Megret offers a different position:

It may be helpful to think creatively about a unique status for children. Specifically, it could be helpful to treat child soldiers as either noncombatant members of the armed forces (akin to medical or religious military personnel, notwithstanding the fact that they may potentially engage in hostilities), or as non-combatants tout court (despite the fact that they are actually members of the armed forces who would normally be targetable as such), subject to the exception that they may be treated as combatants if and only to the extent that they participate in hostilities, in the sense that that expression is understood in relation to civilians. This is an intermediary position fashioned from the normative clay that is the basis of international humanitarian law. It is not one that is sustained by anybody of practice, let alone opinio juris. Nonetheless, I see it as striking a fair middle ground between the repulsive idea of knowingly targeting children who should never have been on the battlefield in the first place, and the evident risk to one's troops of treating what are actual combatants with, as it were, "kids' gloves. It gives child soldiers an extra chance, although no guarantee that if they participate in hostilities that they will escape unscathed; it reinforces the idea that it is the duty of all responsible parties to an armed conflict to protect childhood within the bounds of military necessity, narrowly understood. ${ }^{206}$

Both positions, despite being at variance with each other, acknowledge

International Humanitarian Law's position of attributing a combatant status to a child soldier who has been legally recruited. If the child is a regular member of the armed forces, the rules of International Humanitarian Law apply as it would to a regular combatant.

Disagreements are common. As an illustration, Ang (2005) provides a dissenting position from the previous two. She asserts that the rules of International Humanitarian Law relevant to the child, which come from the Geneva Conventions and their Additional Protocols... "provide two categories of protections: on the one hand, there are rules

\footnotetext{
206 Provost, René, Blog: “Targeting Child Soldiers”, Jan. 12, 2016. http://www.ejiltalk.org/targeting-childsoldiers/, para.3.
} 
regulating the treatment of child civilians, and on the other hand, there are those regulating the treatment of child combatants. About the first category Ang affirms that child civilians benefit from the 'general protection' in their capacity as civilians and from a 'special protection' in their capacity as children. ${ }^{, 207}$ In the CRC, these protections are present in the second, third and fourth paragraphs of Article 38. However, an opinion shared by most scholars writing on Article 38 of the CRC is that paragraphs two and three under the heading 'participation in hostilities and recruitment' apply to child combatant, while paragraph 4, under the heading 'protection and care of civilians', applies to child civilians. ${ }^{208}$ In Ang's opinion, this dissonance does not make sense since "the child combatant does not benefit very much from the protection from participation in hostilities or recruitment since he or she is already fighting, or he or she is already a member of the armed forces. ${ }^{209}$ Therefore, child combatants should not be excluded from the protections awarded to children under the $\mathrm{CRC}$ and treaties of Humanitarian Law. ${ }^{210}$

The rules regulating the treatment of child combatants are part of the rules of International Humanitarian Law relevant to the child, fully applicable to the States Parties...Under International Humanitarian Law, captured child combatants are entitled to the extensive and vigorous protection granted to prisoners of war, notwithstanding the possibility to qualify child combatants as 'unlawful combatants'. This protection includes important guarantees such as the right to humane treatment. 'Child war criminals' also receive a specific treatment with a view to their young age. However,

\footnotetext{
${ }^{207}$ Ang, Article 38: Children in Armed Conflicts, 26.

${ }^{208}$ Ang, Article 38: Children in Armed Conflicts, 28.

${ }^{209}$ Ang, Article 38: Children in Armed Conflicts, 28.

${ }^{210}$ Ang, Article 38: Children in Armed Conflicts, 28.
} 
the situation of child combatants who are not captured is not explicitly regulated under International Humanitarian Law. ${ }^{211}$

"International Human Rights Law on the other hand, differently than International Humanitarian Law, does not differentiate between 'combatants' and 'civilians.' Such categorization could logically be understood as going against the concept of human rights itself." ${ }^{212}$ In International Human Rights Law, children, are awarded certain legal protection available to them in times of peace and in times of war and " the Committee on the Rights of the Child indeed predominantly speaks of the rights of 'children' in armed conflict, without making a further distinction" 213 which allows us to conclude that all children are entitled to the same level of protections. ${ }^{214}$

It is worthwhile to call attention once again for the sake of clarity on how differently International Human Rights Law and International Humanitarian Law conceptualizes child soldiers. In International Human Rights Law, when a person below the age of eighteen is recruited, he or she is considered a child, as stipulated by the CRC; however, "the Geneva Conventions and Additional Protocols (International Humanitarian Law) use different age-limits on different protective measures for children...fifteen [being] the most common.",215

\footnotetext{
211 Ang, Article 38: Children in Armed Conflicts, 28.

212 Ang, Article 38: Children in Armed Conflicts, 29.

${ }^{213}$ Ang, Article 38: Children in Armed Conflicts, 29.

214 Ang, Article 38: Children in Armed Conflicts, 29.

215 "Rule 135: Children, Definition of children," ICRC Handbook of Customary IHL: https://ihldatabases.icrc.org/customary-ihl/eng/docs/v1 cha chapter39 rule135
} 
So, a young recruit at age sixteen is considered a child soldier in International

Human Rights Law, but may not be considered a child at all under International

Humanitarian Law.

An additional side note on misrepresentation of lex lata $^{216}$ by the ICRC and the Office of the Special Representative of the Secretary-General for Children and Armed Conflicts

\section{Rule 136 of the ICRC Handbook of Customary International Humanitarian Law} states that "children must not be recruited into armed forces or armed groups" and "the ICRC has recognized this rule as customary International Humanitarian Law as it reflects State practice...applicable in both international and non-international armed conflicts." The text also affirms that Additional Protocols I and II prohibitions are reflected in the Convention on the Rights of the Child... ${ }^{, 217}$ As much as the last sentence is accurate, and reflection does not necessarily mean replication, we have seen earlier in the present chapter that the Additional Protocols prohibitions against the recruitment and use of children in armed forces and armed groups apply exclusively to those below the age of fifteen, and not for those older.

Therefore, the affirmation made by the ICRC found in the Handbook of Customary International Humanitarian Law that customary International Humanitarian Law as reflected in Additional Protocols I and II and the CRC prohibits the recruitment of children is in the best intention anachronic, and can only be found to be true before

\footnotetext{
${ }^{216}$ Lex lata is understood as: "Ratified law; the positive law currently in force, without modification to account for any rules subjectively preferred by the interpreter..." Fellmeth, Aaron and Maurice Horwitz. "Lex lata", Guide to Latin in International Law. Oxford University Press 2009, 169.

${ }^{217}$ ICRC Customary IHL Database, "Rule 136: Recruitment of Child Soldiers”, https://International Humanitarian Law-databases.icrc.org/customary-International Humanitarian Law/eng/docs/v1 cha chapter39 rule136
} 
1989 - the year in which the CRC raised the age limit of children to include all persons below eighteen. ${ }^{218}$

To better explain: The Additional Protocols to the Geneva Conventions only prohibit the recruitment and use of children below fifteen, despite the fact that eleven years later the $\mathrm{CRC}$ has raised the age limit of childhood to eighteen, considering anyone under eighteen to be a child. Quite confusingly, the CRC has keeps the language used in the Additional Protocols, prohibiting the recruitment and use of children below the age of fifteen (and not eighteen). So, if the CRC were to outlaw/ban the recruitment of children, it would need to extend the prohibition of recruitment to all of those below the age of eighteen, which is not the case (the convention continues to prohibits the recruitment and use of those below fifteen).

On its web page, the Office of the Special Representative of the Secretary-

General for Children and Armed Conflicts states that:

Human rights law declares eighteen as the minimum legal age for recruitment and use of children in hostilities. Recruiting and using children under the age of fifteen as soldiers are prohibited under international humanitarian law - treaty, and custom - and is defined as a war crime by the International Criminal Court. Parties to conflict that recruit and use children are listed by the Secretary-General in the annexes of his annual report on children and armed conflict. ${ }^{219}$

After the exposition of the current chapter, we can easily reach the conclusion that the above statement does not accurately reflect the current status of international law. Recruitment of children fifteen and above by the armed forces is allowed by the CRC

\footnotetext{
${ }^{219}$ The United Nations Office of the Special Representative of the Secretary-General for the Children and Armed Conflict, "Child Recruitment and Use," https://childrenandarmedconflict.un.org/effects-ofconflict/six-grave-violations/child-soldiers/.
} 
which is recognized as a human rights treaty with possible universal application. OPAC itself allows for voluntary recruitment of those sixteen and above when following certain safe measures. At best, one can say that the use of children in hostilities is discouraged by legal authorities, but not forbidden by International Humanitarian Law or International Human Rights Law.

It is unfortunate (yet comprehensible) that the ICRC and the Special Representative, two important sources of information on the existing legislation of the topic of child protection and military recruitment, would inadequately represent existing law, thus allowing their concepts of how the law should function to override their commitment to adequately inform what the law is.

The current chapter addresses the current laws (treaty law and customary law) related to the protection of children from recruitment and use in armed conflicts. International law partly addresses the problem of child soldiering by creating prohibitions for states and armed groups against the recruitment and use children under fifteen.

The chapter calls attention to the permissive character of the current law, allowing the recruitment and use of children at and over the age of fifteen - under customary International Humanitarian Law and International Human Rights Law - and sixteen for State parties to the OPAC (International Human Rights Law), thus clearly failing to protect those under eighteen. 
Chapter 6: How International Law currently deals with child soldiers: a relationship marked by inconsistencies

The predominant story of child soldiering as told by international organizations, and academics is one in which the child is placed almost exclusively in the place of the victim, despite the possibility of the child be accused of an international crime. However, some academics and UN officials have begun to challenge this singular story of the child victim. The present chapter presents a few of these divergent positions, which have embarked and opened the door to an investigation fed by legal considerations which frames a different story: If the child is legally recruited, he or she is competent enough to respond for his or her criminal acts. Authors such as Leveau have identified the position of child criminal responsibility as one licensed by international law. These differing accounts have instituted different sets of imageries questioning the overwhelming representation of the child victimhood.

\section{A discussion of the Minimum Age of Criminal Responsibility (MACR)}

To engage in a discussion of criminal responsibility (MACR) of children under international law, the first step is to delineate how criminal systems in general determine who can be subjected to criminal rules. In all domestic legal systems, an individual is considered capable of infringing criminal laws only after certain criteria are met, for example, a minimum age is required, as also the accused being considered legally competent.

The minimum age by which can be considered a target of the criminal law is denominated 'minimum age of of criminal responsibility' or MACR. The aim of establishing an MACR is to answer the question: starting at what age may children be 
understood as capable enough to be considered capable and culpable of infringing penal law? The MACR does not respond if children, overall, may or may not infringe criminal laws. The underlying assumption when fixing a MACR is that children are capable of breaching the law, and can be held legally responsible for their wrongdoing, but only upon reaching a certain age. The MACR then demarcates the beginning of legal competency when the child in the eyes of the criminal system is deemed legally capable of holding obligations and being subjected to penal accountability.

The MACR set by policy makers and legal systems results in an "agecompetency connection" which "fixe[s] age limits, and forces the difficult link between competency and rights. Such a connection is made to establish, even though arbitrarily, a minimum functioning age at which an individual can be legally prosecuted for crimes.,220 This age of minimum functioning is also intrinsically related to how childhood is seen and treated within that specific society. Thus allowing for a complex concept such as "childhood" which "...bundles together ideas and expectations about young people and their roles in societies, and, as such, its meaning is socially constructed and varies over time within and across cultures" [to be translated into more precise workable age limits which mark the boundaries of childhood and adolescence.] ${ }^{221}$ It ideally expresses society's acknowledgment "that the child has attained the emotional, mental and intellectual maturity to be held responsible for their [criminal] actions...In nearly all

\footnotetext{
${ }^{220}$ Cipriani, Children's Rights and the Minimum Age of Criminal Responsibility: A Global Perspective, 3. ${ }^{221}$ Cipriani, Children's Rights and the Minimum Age of Criminal Responsibility: A Global Perspective, 23.
} 
countries, children above the age of criminal responsibility "may in principle be subject to arrest, detention, and imprisonment." ${ }^{, 22}$

Below the MACR, the child is frequently presumed excused from criminal liability due to lack of legal competence, which can also be translated into the absence of mens rea (infancy defense). In other words: "children younger than the prescribed age are assumed legally incompetent in that context [criminal laws]. They still enjoy protection rights for their relevant interests, but not liberty rights to assert their interests on their own behalf." ${ }^{223}$ What Cipriani is saying is that children below the MACR are vested with protection rights, rights given by the state and overseen by parents and guardians to guarantee some degree of guardianship, as well as fewer liberty rights, which are entitlements offered to individuals after they have achieved a certain level of maturity, such as the right to drink, to marry, to drive.

Also, the MACR should not be confused with the age of majority. The age of majority indicates that the individual has attained the age to be considered a legal adult, capacity wise. So, if the person above the MACR is to violate criminal law, he or she will be potentially answerable to in the 'adult penal system. ${ }^{, 224}$ Differently, a child perpetrator who has achieved the age of MACR, but not the age of majority he or she is, in most cases, deemed answerable for her acts in a juvenile justice system. Less common is having a child who has reached the MACR subjected to an adult-oriented, formal

\footnotetext{
${ }^{222}$ Cipriani, "The minimum age of criminal responsibility," https://www.penalreform.org/wpcontent/uploads/2013/05/justice-for-children-briefing-4-v6-web_0.pdf, February 2013, para.2.

${ }^{223}$ Cipriani, Children's Rights and the Minimum Age of Criminal Responsibility: A Global Perspective, 3.

${ }^{224}$ Cipriani, Children's Rights and the Minimum Age of Criminal Responsibility: A Global Perspective, xiii.
} 
criminal prosecution, but it can happen. The allocation of the child to a juvenile or adult justice system is entirely up to domestic authorities and legislation. In some countries and in the case of the United States, some states, depending on the crime and the age of accused, children can be tried by the adult criminal system despite having not achieved the age of majority.

So, at the domestic level, states adopt different MACRs based on their cultural understandings of childhood, ranging from as low as six up to eighteen years of age. The median age worldwide is twelve. ${ }^{225}$

The legal treatment of the young, when accused of breaching penal laws is not exclusively determined by him/her having reached (or not) the minimum age, other factors are also taken in consideration when deciding upon culpability of a child such as the presence of duress or a mental illness (factors that would also affect an adult's criminal responsibility).

In the international legal arena, Article 40.4 of the Convention on the Rights of the Child (CRC) requires states to establish an MACR operational within national jurisdiction: "States shall seek to promote the establishment of a minimum age below which children shall be presumed not to have the capacity to infringe the penal law [again within the national system; and (b) Whenever appropriate and desirable, measures for dealing with such children without resorting to judicial proceedings, providing that

\footnotetext{
${ }^{225}$ Cipriani, Don. "The Minimum Age of Criminal Responsibility." Penal Reform International/ UKaid. N.p., Feb. 2013. Web. 6 Apr. 2017.
} 
human rights and legal safeguards are fully respected." ${ }^{226}$ The present provision does not create the obligation for states to set a certain pre-established minimum age of criminal responsibility; states are at liberty to choose the minimum age applicable within their national jurisdiction, thus honoring historical and cultural differences in relation to the concept of childhood and perceptions of youth competence. The only stipulation made by the Committee of the $\mathrm{CRC}$ is states should to not fix the minimum age "too low bearing in mind the facts of emotional, mental and intellectual maturity."227

In international criminal law, no universal MACR has been established, so it is not clear what the minimum age of criminal responsibility is with respect to those who have committed international crimes. In Happold's words: “...it is unclear whether international law fixes a minimum age of criminal responsibility at all." ${ }^{228}$ Drumbl argues that states, having failed to produce any consensus on where the MACR should stands, mirror the position of the ICC of intentionally excluding persons under the age of eighteen at the time of the alleged offense from its jurisdiction. The exclusion was a result of the drafters failing to reach an agreement on whether children would be held accountable by the court. And after a consensus position failed to be reached, "the Working Group on General Principles agreed to impose a 'jurisdictional solution' reflected in in Article 26 simply stating that the Court would be unable to prosecute

\footnotetext{
${ }^{226}$ Articles 40 of the CRC also stipulates certain basic minimum standards of juvenile justice criteria which all State parties must abide by when holding a child (someone younger than eighteen) criminally responsible. These protections, established by an international human rights treaty, are to apply at all times (in times of conflict and in times of peace) and they address children in conflict with national law, not necessarily international law.

${ }^{227}$ Committee on the Rights of the Child, 2007 and Happold "The Age of Criminal Responsibility for International Crimes Under International Law," 6.

${ }^{228}$ Happold, "The Age of Criminal Responsibility for International Crimes Under International Law," 3-4.
} 
persons who were under eighteen at the time of the commission of the crime."229

The ICC decision to exclude minors, according to the International Criminal Tribunal for the former Yugoslavia " is purely jurisdictional in nature" and "the proposition that there was no criminal responsibility for crimes committed by persons under the age of eighteen 'is completely unfounded in law' under either conventional or customary international law." ${ }^{230}$ Going against the legal argument, Drumbl identifies a growing tendency "among states, UN agencies, global civil society, as well as those lawyers who operate and staff these institutions" to exclude those under eighteen from the jurisdiction of international or internationalized institutions. ${ }^{231}$

The absence of an international standard for MACR is seen by many academics and jurists as an obstacle when trying to determine where International Criminal Law stands on the issue of the individual responsibility of minors. As stated by Grover (2012), establishing a universal MACR is a pre-requisite for claims of responsibility or the prosecution of children by international courts:

Formulating a universal minimum age of criminal culpability for international crimes will seem an absolute prerequisite if States wish to prosecute persons who were under 18 years old at the time they committed an international crime (i.e. war crime, crime against humanity or genocide) in a manner that is legally supportable regarding equity. The absence of such a universal minimum age is then an absolute bar, in principle at least, to the prosecution of children for international crimes. ${ }^{232}$

\footnotetext{
${ }^{229}$ Schabas, The International Criminal Court: A Commentary on the Rome Statute, 2007, 72.

${ }^{230}$ Oric, para. 400 (ICTY 30 June 2006) cited by Schabas, The International Criminal Court: A Commentary on the Rome Statute, 2007, 72.

${ }^{231}$ Drumbl, Reimagining Child Soldiers in International Law and Policy, 117.

${ }^{232}$ Grover, Child Soldier Victims of Genocidal Forcible Transfer Exonerating Child Soldiers Charged with Grave Conflict-related International Crimes, 69-70.
} 
Grover here makes an important point: the establishment of an age of legal competence is an essential criterion for the attribution of individual criminal responsibility for those under eighteen. Without the institutionalization of such landmark, we are not sure where International Criminal Law stands on the issue of children's criminal responsibility.

\section{Children before the UN ad hoc tribunals and the ICC}

What we know is, up to date, no child has ever been prosecuted under international law, either by international criminal tribunals or by a domestic court utilizing international law. In the few instances in which child soldiers were brought to trial, they were tried for ordinary crimes under national legislation, and not for international crimes under international law. ${ }^{233}$

Until the Special Court for Sierra Leone (SCSL), no international court had included children (individuals below eighteen) under its jurisdiction. The International Criminal Tribunal for Yugoslavia (ICTY) and the International Criminal Tribunal for Rwanda (ICTR) granted jurisdiction over 'natural persons' as stated in both Statutes (Arts. 6 and 5, respectively) which would technically include children, but no specific mention of children was made in either Statute, and no cases including children defendants were tried. ${ }^{234}$

\footnotetext{
${ }^{233}$ Happold, "The Age of Criminal Responsibility for International Crimes Under International Law," 1.

${ }^{234}$ Leveau, "Liability of Child Soldiers Under International Criminal Law," 41.
} 
After the SCSL, nonetheless, two hybrid courts: the Special Tribunal for Lebanon and the Special Panels for Serious Crimes for Timor-Leste, included minors between the ages of twelve and sixteen years in their Statutes, which would suggest that the norms and legal principles developed by the SCSL have exerted direct influence in the work of the most recent 'hybrid' courts. ${ }^{235}$

\section{Criminal responsibility of child soldiers under current International Law}

International criminal courts, more specifically the International Criminal Court

(ICC) and the Special Court for Sierra Leone (SCSL) have codified the act of recruiting and using children below the age of fifteen in armed conflicts as the crime of child soldiering. The crime of child soldiering was given the status of an international crimes. 236 "The international community and international human rights groups have [also] declared that child soldering is a grave abuse of children's rights." 237 The blame for the crime of child soldering fails over, entirely, on to the adult recruiter or commander. Also, as we have seen, following rules of International Humanitarian Law the criminalization of child soldering only applies when the child is below fifteen, mainly due to the fact that international customary law (Article 38 of the CRC, for example) allows individuals from ages fifteen to seventeen to be legally recruited to serve in armed conflicts. Children ages

\footnotetext{
${ }^{235}$ Schabas, William, The UN International Criminal Tribunals: The Former Yugoslavia, Rwanda, and Sierra Leone (Cambridge, UK: Cambridge University Press, 2006), 44.

${ }^{236}$ In the SCSL Statute, the crime of "conscripting or enlisting children under the age of fifteen years into the national armed forces or using them to participate actively in hostilities" was considered a serious violation of international humanitarian law (Article 4), while in the Rome Statute, the crime of was labeled under the category of war crimes (Article 8).

${ }^{237}$ Rivard, Lysanne,"Child Soldiers and Disarmament, Demobilization and Reintegration Programs: The Universalism of Children's Rights vs. Cultural Relativism Debate," The Journal of Humanitarian Assistance, (August 23, 2010): https://sites.tufts.edu/jha/archives/772.
} 
fifteen to seventeen at the time of the recruitment fall into a legal gap of protection and are not condemned by international criminal law as targets of child soldiering. Instead, they are merely considered young soldiers. Also, as shown in previous chapters, International Humanitarian Law treats young soldiers as lawful combatants, who are legally entitled to the same level of protection as older soldiers (see the discussion in previous chapters regarding the status of legal combatant attributed to young soldiers).

The allegation that child soldiering violates children's rights, while commonly found in the international discourse, carries inconsistencies. The recruitment of children for military purposes challenges moral concepts of childhood, no doubt, and it can be said to even run counter to the overall intention of most children's rights treaties, yet, the enlistment of persons under eighteen in military service is still allowed under all international children's treaties currently in force.

Freeland (2010) is also correct in highlighting the sense of inconsistency present in the legal treatment of the child involved in child soldiering: while the SCSL recognizes the potential criminal responsibility of those fifteen and over, the ICC refuses to exercise jurisdiction over those under the age of eighteen.

On the one hand, international law by allowing legal recruitment at age fifteen yet not establishing a position on whether these young qualify for criminal prosecution seems to communicate exclusively that there is no criminal wrongdoing in engaging children of 15,16 or 17 years in armed conflict, and if these children are involved in serious violations of international law, then this is just unfortunate. The ICC is not mandated to examine the actions of individuals under eighteen, even where they might have committed international crimes. ${ }^{238}$

\footnotetext{
${ }^{238}$ Freeland, "How International Law Deals with Child Soldiers," 8.
} 
It is difficult to reconcile the apparent desire of the international community to protect children under the age of 18 from participating in armed conflict with the criminalization of recruitment activities only in respect of children below the age of 15 years. One can surely accept an argument that the recruitment or use of children of, for example, 15 years of age does constitute (in the absence of other factors that may properly negate criminal responsibility) an action that is at odds with the basic norms that have now been set by the international community. Such an action could and should constitute an international crime and the definitions in the Rome Statute should be 'upgraded' accordingly... ${ }^{239}$

Cassese clearly expressed the legal gaps in how current international law frames the issue of child soldiers and criminal accountability: "It follows that a state, a national liberation movement or insurgent [and national armies] may lawfully enlist children of sixteen or seventeen - but if these children engage in criminal conduct, they are not amenable to judicial process before the ICC (although these children could be brought to trial before national courts, assuming such courts have jurisdiction over them). ${ }^{240}$

Cassese is also on target identifying the ICC decision to exclude persons under the age of eighteen from the jurisdiction of the court (Article 26) as one which would not necessarily point to the existence of “.... a substantive rule of criminal law whereby minors may not be held criminally responsible." ${ }^{241}$ "It follows that, under that provision, it would be lawful for a contracting party to bring to trial before its national courts persons under eighteen for allegedly committing war crimes if this were allowed under the relevant national legislation." ${ }^{242}$

\footnotetext{
${ }^{239}$ Freeland, "How International Law Deals with Child Soldiers," 7.

${ }^{240}$ Cassese, International Criminal Law, 267.

${ }^{241}$ Cassese, International Criminal Law, 267.

${ }^{242}$ Cassese, International Criminal Law, 267.
} 
Divergent positions: International law allows for the incrimination of children accused of war crimes

Against the morally inclined positions held by IOs, NGOs, and academics alike that children should not be targeted by international criminal law, and that legal provisions should instead focus on prohibiting crimes committed against children and not by children; there is a growing tendency among a few academics to offer a contrasting position.

Leveau's article "Liability of Child Soldiers under International Criminal Law" (2013) successfully focuses on the responsibility of the child soldier and illustrates how international law does, in fact, allow for the exercise of criminal responsibility on those under the age of eighteen when accused of grave violations of international law. In the present article, the author brings attention to crimes committed by children, instead of crimes against children. She acknowledges children as perpetrators, and discusses their potential criminal responsibility under international criminal law. In her opinion "interpretation of [legal] instruments suggest that child soldiers could be prosecuted by international criminal tribunals, ${ }^{243}$ while still having to respect certain specific juvenile justice standards, already established by international law.

Leveau goes on to present three reasons why prosecution of those under eighteen should be available in international criminal law. First, she argues that bringing to justice those who have committed international crimes is the aim of international criminal justice; second, it is understood as authorized by international human rights law; and

\footnotetext{
${ }^{243}$ Leveau, "Liability of Child Soldiers Under International Criminal Law," 36.
} 
third, most domestic systems already allow prosecutions of child soldiers and, in fact, some have done so. ${ }^{244}$

Leveau is categorical in defending the view that prosecution of child soldiers is allowed by international human rights law. According to her, international human rights law does not prohibit child prosecution. The CRC, for example, contains chapters specifically on children in conflict with the law (even though the convention does not explicitly authorize or prohibit the prosecution of children), thus acknowledging that the legal prosecution of children is possible, at least in theory and within domestic legal systems. $^{245}$ The wide ratification of the $\mathrm{CRC}$ is for her, a strong indication that states agree that: "child prosecution could occur and a fortiori is authorized."246

The fact that an international treaty as widely ratified as the CRC recognizes that prosecution of children can occur at a domestic level impacts our understanding of international law. Indeed, provisions of the CRC have crystallized under customary international law. Indirectly, this indicates that the international community is not substantially opposed to the prosecution of children at the international level. ${ }^{247}$

A common position against the viable prosecution of child soldiers in

International Law comes from critics who argue that even though children in most criminal system are deemed capable of forming mens rea for ordinary crimes, this does necessarily entail the competence to form the means rea necessary for an international crime. ${ }^{248}$ These authors have pointed to the fact that international crimes, unlike most

\footnotetext{
${ }^{244}$ Leveau, "Liability of Child Soldiers Under International Criminal Law," 43.

${ }^{245}$ Leveau, "Liability of Child Soldiers Under International Criminal Law," 51.

${ }^{246}$ Leveau, "Liability of Child Soldiers Under International Criminal Law," 51.

${ }^{247}$ Leveau, "Liability of Child Soldiers Under International Criminal Law," 51.

${ }^{248}$ Leveau, "Liability of Child Soldiers Under International Criminal Law," 52.
} 
ordinary crimes, require a more complex mens rea requirement, which may prove to be extremely difficult for a child to acquire. ${ }^{249}$ To address this valuable line of questioning, Leveau presents the argument set forth by Happold (2008) in which he explains that with the exception of the crime of genocide, the international requirements for international crimes are not more complex than domestic crimes.

Most international crimes [with the exception of genocide] ... do not require proof of any special intent. They merely require knowledge of the existence of particular circumstances. Crimes against humanity have a contextual element, calling for proof that they were "committed as part of a widespread or systematic attack directed against the civilian population,' but it needs only to be shown that ' $[t]$ he perpetrator knew that the conduct was part of such an attack' (Rome Statute, Article 7). War crimes require that the prohibited conduct "took place in the context of and was associated with" an armed conflict but only require proof that " $[t]$ he perpetrator was aware of factual circumstances that established the existence' of the conflict. In most cases, therefore, the problem would seem to be one of proof rather than of principle. For example, it's hard to envisage a child soldier being successfully prosecuted for the international crime of aggression. However, this is because child soldiers do not hold sufficiently exalted rank to participate in decisions to wage aggressive war. Indeed, one might go further and say that there is no principled difference between the issues arising from attempts to hold children responsible for complex domestic and complex international crimes. At best, the argument is over-inclusive. In each case the difficulties will be the same and, as a result, the argument cannot be used to distinguish children's legal responsibility for international crimes from their criminal responsibility in domestic law. ${ }^{250}$

In other words, according to existing international criminal law, as set by the ICC, a juvenile can indeed qualify as having met the mens rea criterion for the prosecution for international crimes, since "most international crimes ... do not require proof of any

\footnotetext{
${ }^{249}$ Happold, Matthew, “Child Soldiers: Victims or Perpetrator?" University of La Verne Law Review (2008) Web. 8 Sept. 2015, 72.

${ }^{250}$ Happold, Matthew, "Child Soldiers: Victims or Perpetrator?" University of La Verne Law Review (2008) Web. 8 Sept. 2015, 72-3.
} 
special intent. They merely require knowledge of the existence of particular circumstances [again with the exception of genocide]."251

One of the other main concerns of those who oppose the idea of children's prosecution under International Criminal Law is the idea that prosecution can never be conducted in a way that can deliver proper rehabilitation to the child accused, as well as, be considered in the child's best interest. Leveau makes a compelling counterargument explaining that if done with the intention of rehabilitation, holding a child criminally liable can, in fact, help the child return to society without the stigma of impunity:

...by condemning a child to low sentences [which] may help them reintegrate into society while they are still young, and society would feel that the wrongs committed by child soldiers have been dealt with. It may also be more inclined to reaccept them and move forward. ${ }^{252 ،}$ Besides, one of the central aims of international criminal law is to bring justice to the victims and "one can hardly imagine how victims of child soldiers would reaccept these children as part of their community without feeling that justice had been done." ${ }^{, 53}$

To sum, despite the large majority of authors defending the position that children should not, as a matter of morals, or a matter of law, be liable for criminal prosecution under International Criminal Law, most recent (yet sparse) literature has successfully shown the existence of legal interpretations and lines of reasoning supporting the viability of children to be subject to the principle of individual criminal responsibility under international criminal law when accused of the commission of war crimes.

\footnotetext{
${ }^{251}$ Happold, Matthew, "Child Soldiers: Victims or Perpetrator? ." University of La Verne Law Review (2008) Web. 8 Sept. 2015, 72-3.

${ }^{252}$ Leveau, "Liability of Child Soldiers Under International Criminal Law," 48.

${ }^{253}$ Leveau, "Liability of Child Soldiers Under International Criminal Law," 49.
} 
Chapter 7: International tribunals and the contribution of the SCSL to the emerging law on children's criminal responsibility in International Criminal Law

The current chapter argues in favor of the UN Security Council and the UN Secretary General, via the Statute of the Special Court for Sierra Leone, generating a legal rule which clearly establishes individual criminal responsibility on minors, starting at age fifteen, when accused of serious breaches of international law. This rule is influential towards the general development of international criminal law, since other international and domestic courts alike are able to use the precedent to bring juveniles to justice under the accusation of international crimes.

However, before reaching this conclusion, the chapter starts with an overview of international criminal law and the workings of the international criminal tribunals. These two - international criminal law and international criminal courts - are associated in the current analysis precisely because it is through the creation and functioning of international criminal courts that International Criminal Law has experienced its greatest development, expansion, and precision. Next, we will examine the workings of the Special Court for Sierra Leone, in particular its jurisdictional contribution as the first international court to include juveniles as viable subjects of its international criminal jurisdiction. The inclusion of minors is articulated in Article 7(1) of the court's Statute. The Statute was first developed by the UN Secretary General, in consultation with the government of Sierra Leone, and has received support and authorization from the UN Security Council. It will be argued that the decision of the Statute's authors to include jurisdiction over minors, despite not having framed it as compulsory, can nonetheless be used as evidence of law, inviting other courts to do so when ruling on similar cases. The 
chapter concludes with a revealing interpretation: by including juveniles under the jurisdiction of the SCSL, the UN Secretary General has acknowledged that juveniles, after the age of minimum legal recruitment, set at age fifteen, can be considered viable subjects of the international criminal system.

\section{International criminal tribunals: an introduction}

By the end of the Second World War, Europe had witnessed a level of human catastrophe shocking to the international community, reaching what was considered a moral tipping point. Moved by the rationale "never again," the Allies established, via a multilateral treaty (London Agreement of August, $\left.8^{\text {th }} 1945\right)$, the first International Military Tribunal (IMT) located in Nuremberg, Germany. The court aimed at convicting Nazi war officials for war crimes, crimes against humanity and waging aggressive war. ${ }^{254}$

One year later, a second military tribunal, the International Military Tribunal for the Far East, also known as the Tokyo Tribunal took place following the same purpose. The Tokyo Tribunal was also established by an international agreement between the Allies towards the prosecution of Japanese war officials. Operating similarly to its predecessor and holding jurisdiction over the same list of crimes (crimes against peace, war crimes and crimes against humanity) ${ }^{255}$ the court successfully brought twenty-eight defendants to justice. ${ }^{256}$

\footnotetext{
${ }^{254}$ The Robert H. Jackson Center, "The Influence of the Nuremberg Trial on International Criminal Law,", "https://www.roberthjackson.org/speech-and-writing/the-influence-of-the-nuremberg-trial-on-internationalcriminal-law/

${ }^{255}$ Charter of the International Military Tribunal for the Far East.

256 "The Influence of the Nuremberg Trial on International Criminal Law," The Robert H. Jackson Center, https://www.roberthjackson.org/speech-and-writing/the-influence-of-the-nuremberg-trial-on-internationalcriminal-law/
} 
In terms of legacy, both courts inaugurated a new period in international law by institutionalizing the legal principle of individual criminal responsibility; a principle which acts imposing criminal responsibilities directly on to individuals without the need of State intermediation. As a result, an individual can be brought to justice exclusively through international mechanisms. ${ }^{257}$

The rationale behind the legal premise of individual's criminal accountability was that: "never again" would state sovereignty shield those who have committed gross human atrocities, and "never again" would State sovereignty affect the obstruction of justice of those who seriously violated International Humanitarian Law. Individuals would receive protection from international law against wide-scale atrocities wherever they are performed. ${ }^{258}$ "The Nuremberg trials established that all of humanity would be guarded by an international legal shield...,259

Efforts at creating an international individual accountability system were also a direct response to the incapacity or unwillingness of local courts to bring to trial those responsible for internationally criminal acts, as well as the desire shared by the Allies of sending a clear message to the rest of the world that human atrocities committed by a government would no longer be tolerated. Sovereignty would no longer act as a shield protecting authorities accused of committing atrocities.

\footnotetext{
${ }^{257}$ Cryer at al, An introduction to international criminal law and procedure. 1st ed. (Cambridge: Cambridge University Press, 2007), 1.

${ }^{258}$ Cryer at al, An introduction to international criminal law and procedure. 1 st ed. (Cambridge: Cambridge University Press, 2007), 1.

259 "The Influence of the Nuremberg Trial on International Criminal Law," Robert H. Jackson Center, https://www.roberthjackson.org/speech-and-writing/the-influence-of-the-nuremberg-trial-on-internationalcriminal-law/.
} 
The legacy that started with the Nuremberg trials marked the birth of modern International Criminal Law. The codification of a branch of international law responsible for criminalizing violations of IHR and International Human Rights Law, including by governmental agents, through international and national courts was only possible through a process that pierced through the sacrosanct institution of sovereignty.

The new legal paradigm introduced was well defined by Nuremberg's famous declaration that "crimes against international law are committed by men, not abstract entities, and only by punishing individuals who commit such crimes can the provisions of international law be enforced." 260 The perpetrators were to be held directly accountable "without the intermediary of the state wielding authority over such individuals," even in cases when the accused was in fact acting as an official representative of a State. ${ }^{261}$

The process, the establishment of individual criminal responsibility under international law, faced two main obstacles: first, in classical international law, states, not individuals, were the exclusive subjects. Therefore, the establishment of criminal norms in international law first required the recognition of the individual as a subject of international law. Second, it was necessary to overcome states' defensive attitude towards outside interference, which was rooted in the concept of sovereignty. ${ }^{262}$

If we take a step back, before the establishment of the Nuremberg tribunal, it is important to mention that International Law traditionally did not address individuals, only states and state representatives. ${ }^{263}$ Individuals, in their private capacity, were not

\footnotetext{
${ }^{260}$ Cryer et al., An introduction to international criminal law and procedure, 752-3.

${ }^{261}$ Cassese, International Criminal Law, 3.

${ }^{262}$ Werle, G. and Bung, J, “The evolution of international criminal law, 2010: http://werle.rewi.huberlin.de/01 History-Summary.pdf.

${ }^{263}$ With the exceptions of pirates and slave traders.
} 
understood as capable of infringing international law ${ }^{264}$ and any act performed by an individual was to be addressed by the State concerned and through the works of domestic courts. International law also did not prescribe punitive measures. When a sate was in violation of its international obligations, the accused state was under the duty to discontinue the violation and grant some form of reparation. Rules of international responsibility evolved through customs and were later codified by the International Law Commission in 'Responsibility of States for Internationally Wrongful Acts' (2001) and submitted to the UN General Assembly.

The IMT challenged the traditional view by affirming that: "individuals [based on customs] have international duties which transcend the national obligations of obedience imposed by the individual State. ${ }^{, 265}$ In this statement, the court was mostly referring to obligations derived from International Humanitarian Law, already binding upon individuals before the creation of the IMT. Attempts to regulate warfare began earlier than the IMT, in, for example, the Hague Conferences of 1899 and 1907; however, the provisions of those conferences' resulting treaties did not prescribe criminal penalties for violation, and were strongly limited by notions of State sovereignty. ${ }^{266}$

\footnotetext{
${ }^{264}$ Cassese, International Criminal Law, 5.

265 "The trial of the Major War Criminals before the International Military Tribunal", Vol. I, Nuremberg. 1947, 223 in Principles of International Law of the Charter and Judgment of the Nuremberg Tribunal, Formulated by the International Law Commission, Second Session Source: International Organization, Vol. 4, No. 4 (Nov. 1950), 714-721, also see: http://avalon.law.yale.edu/imt/judlawch.asp.

266 The Influence of the Nuremberg Trial on International Criminal Law" Robert H. Jackson Center: https://www.roberthjackson.org/speech-and-writing/the-influence-of-the-nuremberg-trial-on-internationalcriminal-law/.
} 
"The Hague Convention nowhere designates such practices [methods of waging war] as criminal, nor is any sentence prescribed, nor any mention made of a court to try and punish offenders." 267

From an institutional legal perspective, the creation of the IMT marked a turning point in international law. With the adoption of the Agreement and the Charter of the IMT, the Allies had created the first "genuinely international body of criminal law capable of universal application that brought together several different legal traditions. ${ }^{, 268}$ Both of these courts were set to try "war criminals whose offenses have no particular geographical location whether they are accused individually or in their capacity as members of organizations or groups or both capacities. ${ }^{.269}$ The IMT Charter established that "individuals could be criminally liable as a matter of international law, rejecting in passing the Defense arguments that international law only provided liability for states, not individuals." ${ }^{270}$

In addition, the IMT institutionalized the idea that individuals had international obligations as a matter of international law, and these obligations were to be given

\footnotetext{
${ }^{267}$ Clapham, Andrew, "Issues of Complexity, Complicity and Complementary: from the Nuremberg trials to the dawn of the new International Criminal Court," From Nuremberg to The Hague: The Future of International Criminal Justice, ed. Sands, Phillipe (Cambridge: Cambridge University Press, 2003), 31.

${ }^{268}$ Mettraux, Guénaël, “Trial at Nuremberg," Routledge Handbook of International Criminal Law, ed. William Schabas and Nadia Bernaz (New York: Routledge, 2011), 6.

${ }^{269}$ Art. 1 of the London Agreement for the Prosecution and Punishment of the Major War Criminals of the European Axis, of 8 August 1945 and Edoardo Greppi, "The Evolution of individual criminality under international law," International Review of the Red Cross, No 835 (September 30, 1999): https://www.google.com/url?sa=t\&rct=j\&q=\&esrc=s\&source=web\&cd=1\&ved=0ahUKEwih643nru3SAh VU22MKHZwzCNsQFggaMAA\&url=http\%3A\%2F\%2Fwww.umass.edu\%2Flegal\%2FBenavides\%2FFall 2004\%2F397G\%2FElectronic\%2520Reserve\%2F12\%2520Greppi.doc\&usg=AFQjCNHeEDIHO6B18My AwyxK7D-dwF1o5w\&bvm=bv.150475504,d.amc.

${ }^{270}$ Mettraux, Guénaël, “Trial at Nuremberg,” Routledge Handbook of International Criminal Law, 11.
} 
precedence over their national duties and responsibilities: individuals were seen to "have international duties which transcend the national obligations of obedience imposed by the individual state. He who violates the laws of war cannot obtain immunity while acting in pursuance of the authority of the state if the state in authorizing action moves outside its competence under international law."271

Possibly one of the most important outcomes of the IMT was the Court's determination that the prohibition of the crimes under its jurisdiction [laid down in the Charter] did not constitute new law. ${ }^{272}$ In the view of the Tribunal, the Charter was the expression of international law existing at the time of its creation; the Charter merely codified the law. This conclusion is disputed by a number of jurists and scholars. "While some claimed that the Charter of the Nuremberg Tribunal merely codified existing principles, others were more forthcoming in acknowledging that, in fact, a great deal of it was new law... If there was no law to punish these crimes, it was the general view that law should be made. And so it was."273

An important point to keep in mind is that subsequent international courts have also adopted the same position: to negate the creation of new law for the sake of not confronting the principle of legality. ${ }^{274}$

\footnotetext{
${ }^{271}$ Mettraux, Guénaël, “Trial at Nuremberg,” Routledge Handbook of International Criminal Law, 11.

${ }^{272}$ Mettraux, Guénaël, "Trial at Nuremberg," Routledge Handbook of International Criminal Law, 11. Also see "Judgement of the Charter": http://avalon.law.yale.edu/imt/judlawch.asp.

${ }^{273}$ Mettraux, Guénaël, “Trial at Nuremberg," Routledge Handbook of International Criminal Law, 7.

274 The principle of legality expresses that "No one may be accused or convicted of a criminal offence on account of any act or omission which did not constitute a criminal offence under national or international law at the time it was committed; nor may a heavier penalty be imposed than that which was applicable at the time the criminal offence was committed." "Rule 101. The Principle of Legality," ICRC Customary Law Database, https://ihl-databases.icrc.org/customary-ihl/eng/docs/v1_rul_rule101
} 
The Nuremberg Tribunal heritage influenced other international law venues, such as the creation of the United Nations Genocide Convention (1948), the Universal Declaration of Human Rights (1948), and the Geneva Conventions on the Laws and Customs of War (1949). The International Military Tribunal also supplied a useful precedent for the trials of Japanese war criminals in Tokyo (1946-48); the 1961 trial of Nazi leader Adolf Eichmann in Israel (1906-62); and the establishment of tribunals for international crimes committed in the former Yugoslavia (1993) and in Rwanda $(1994){ }^{275}$

Bringing the accused to justice: domestic courts and international courts

When states are under the obligation to bring those accused of grave breaches of International Humanitarian Law and International Human Rights Law to justice, the process is mainly done through their domestic courts. ${ }^{276}$ Domestic courts are a paramount element to the delivery of international justice. ${ }^{277}$ The obligation to bring those accused to justice does not exclusively rest on the State in which the crime occurred or the State from which the perpetrator or victims are nationals. These international obligations are shared by international society as a whole and any State that has custody of the accused may exercise jurisdiction over the case, and prosecute the accused.

\footnotetext{
275 The History Channel, "Nuremberg Trials," "Nuremberg Trials," (2010). http://www.history.com/topics/world-war-ii/nuremberg-trials, last accessed Jan.13, 2017.

${ }^{276}$ ICRC, "When violations of IHL occur, states are under an obligation to prosecute alleged offenders" found in: "Violations of IHL," https://www.icrc.org/en/war-and-law/international-criminal-jurisdiction). Last accessed March 23, 2017.

${ }^{277}$ National courts, therefore, play a major role in the enforcement of IHL and limiting impunity" "... found in: ICRC, "Violations of IHL," https://www.icrc.org/en/war-and-law/international-criminaljurisdiction). Last accessed March 23, 2017.
} 
If the State holding custody is not willing to prosecute in good faith, it must extradite to another that is ready to bring the accused to justice.

Before 1945, domestic courts were generally the only way of bringing individuals to justice for violations of international law. However, these violations were judged as breaches of domestic law, and the crimes were considered common national crimes. Each country had a different set of criminal rules and procedures. While the latter still holds true, after 1945 , the international community "...moved increasingly toward the development of a system of international jurisdictions, complementary to that of domestic courts to try people accused of genocide, war crimes and crimes against humanity.",278 Currently, gross violations of International Humanitarian Law and International Human Rights Law carry the obligation of prosecution. States are required either to prosecute and punish an individual accused of committing international crimes, or to extradite them so an interested State can do so. ${ }^{279}$ "Recalling that it is the duty of every State to exercise its criminal jurisdiction over those responsible for international crimes. $" 280$

\footnotetext{
${ }^{278}$ ICRC, “International criminal jurisdiction," https://www.icrc.org/en/document/international-criminaljurisdiction, (October 29, 2010).

${ }^{279}$ Cassese, International Criminal Law, 3.

${ }^{280}$ Preamble, Rome Statute. Anja Seibert-Fohr (2003) has argued otherwise: “... in contrast to the conventions based on the traditional concept of aut dedere aut judicare; the Rome Statute does not include an explicit provision on the obligation to either prosecute or extradite the accused offender"...(2003), and she goes on to say that: "this interpretation seems to be shared by Judges Higgins, Kooijmanns and Buergenthal of the IC] who pointed out in their Joint Separate Opinion in the Case Arrest Warrant of 11 April 2000 (Democratic Republic of the Congo v. Belgium) that jurisdiction "may be exercised [by states] on a voluntary basis" under the Rome Statute. Joint Separate Opinion, para. 51, 79 (2002) cited by SeibertFohr, Anja , "The Relevance of the Rome Statute of the International Criminal Court for Amnesties and Truth Commissions," Max Planck Yearbook of United Nations Law. Ed. A. Von Bogdandy and R. Wolfrum. Vol. 7. (Netherlands.: Koninklijke Brill N.V.), 2003, 558, footnote 22: http://www.mpil.de/files/pdf3/mpunyb_seibert-fohr_7.pdf.
} 
The development of a system of international jurisdiction was possible through the establishment and operation of international courts, which can be divided analytically into three types (international ad hoc criminal courts, hybrid courts, and a permanent criminal court), established in two different settings (post-conflict or permanently). The first two types, ad hoc international criminal courts and other types of internationalized tribunals, such as hybrid courts, were created after the 1990s followed by serious armed conflicts, and were aimed at addressing serious violations arising exclusively from these armed conflicts. Common traits among these two type of courts was that they were United Nations' involvement; they were operated temporarily and held a limited territorial jurisdiction (jurisdiction ratione loci). The major difference between these two (ad hoc courts and hybrid courts) was the first, ad hoc courts, were exclusively international courts, and thus the court followed and responded to international law, while the hybrid courts were composed of a combination of international and national judges and followed both international and domestic law.

The third type of international criminal court is the permanent International Criminal Court (ICC). The ICC came from a prolonged desire of states to build a permanent court to address serious international crimes that could result in means of clashing jurisdiction. A permanent court would also serve to address cases in which states were unwilling to try due to political reasons, or possibly even lack of resources. ${ }^{281}$

\footnotetext{
${ }^{281}$ For more information, see ICRC, "International criminal jurisdiction," https://www.icrc.org/en/document/international-criminal-jurisdiction, (October 29, 2010).
} 
Contributions of the international tribunals from post Second World War to the twenty first century

International tribunals have operated since the beginning of the modern international system, with the purpose of settling disputes between states. These were not criminal courts, however, and they only addressed states. It is mainly with the Nuremberg trials after World War II, however, that ad hoc tribunals dealing with criminal cases against individuals were created to address the core international crimes, namely genocide, war crimes and crimes against humanity. ${ }^{282}$ It is safe to affirm that these international criminal courts have changed the landscape of international law, targeting mainly the individuals responsible for the planning and commission of gross human atrocities. The rationale behind their creation was to assure that when states were either unwilling or incapable of bringing the accused to justice through national legal channels, the international community as a whole might step in to ensure that serious violations of IL do not go unpunished.

\section{The ICTY and ICTR}

The legacy created by the Nuremberg Tribunal allowed the emergence, years later, of the ICTY and the ICTR. The years of 1993 (ICTY) and 1995 marked the creation of the first two "truly" international criminal tribunals to be ever established, ${ }^{283}$ both were created by the UN Security Council as subsidiary organs (extensions) of the

\footnotetext{
282 ICRC, "Ad hoc tribunals," https://www.icrc.org/eng/war-and-law/international-criminaljurisdiction/ad-hoc-tribunals/overview-ad-hoc-tribunals.htm (October 29, 2010).

${ }^{283}$ Jalloh, Charles, Consolidated Legal Texts for the Special Court for Sierra Leone (Leiden, The Netherlands: Martinus Nijhoff Publishers, 2007), 167.
} 
UN under Chapter VII. ${ }^{284}$ These courts were brought to being under the terms of Article 29 of the United Nations Charter, having the United Nations operating within a judicial nature. ${ }^{285}$ The establishment of the ICTY and the ICTR via Chapter VII of the UN Security Council served to “...ensure more expeditious establishment and universal application." 286

Both of these courts had limited temporal and territorial scope. The ICTY exercised authority over "persons responsible for serious violations of international humanitarian law committed in the territory of the former Yugoslavia since 1991 in accordance with the provisions of the present Statute." It has jurisdiction over grave breaches of the 1949 Geneva Conventions, violations of the laws or customs of war, genocide, and crimes against humanity. While the ICTR had jurisdiction (its work ended in 2015) to prosecute persons responsible for serious violations of international humanitarian law committed in the territory of Rwanda or over Rwandan citizens responsible for such violations committed in the territory of neighboring states, between 1 January 1994 and 31 December 1994.

The ICTY Statute was drafted by the UN Office of Legal Affairs, and was approved and adopted by the UN Security Council without alteration. ${ }^{287}$ By comparison,

\footnotetext{
${ }^{284}$ Jalloh, Charles, Consolidated Legal Texts for the Special Court for Sierra Leone (Leiden, The Netherlands: Martinus Nijhoff Publishers, 2007), 172.

${ }^{285}$ Schabas, William. The UN International Criminal Tribunals: The Former Yugoslavia, Rwanda, and Sierra Leone, 48-49.

${ }^{286}$ Scharf, Michael and Margaux Day, "The ad hoc international criminal tribunals: launching a new era of accountability," The Routledge Handbook of International Criminal Law, ed. William Schabas and Nadia Bernaz, (New York: Routledge, 2011), 51.

${ }^{287}$ Scharf, Michael and Margaux Day, "The ad hoc international criminal tribunals: launching a new era of accountability," The Routledge Handbook of International Criminal Law, 52.
} 
when developing the ICTR Statute, the UN Security Council did not request the involvement of the UN Secretary-General or the Office of Legal Affairs, it simply “closely mirrored the Yugoslavia Tribunal's Statute...,"288

\section{The Special Court for Sierra Leone}

A third international court was created by the United Nations in agreement with the government of Sierra Leone in 2002 and it aimed at bringing to justice those most responsible for the International Humanitarian Law violations occurred during the Sierra Leone civil war. The Special Court for Sierra Leone (SCSL) came as a result of "Sierra Leone's request for UN assistance in establishing an independent tribunal to try those responsible for alleged crimes during its decade-long civil war." ${ }^{289}$ A more detailed analysis of the SCSL's characteristics and functioning will be covered subsequently in this chapter.

Other internationalized courts were created after the SCSL, such as the UN Special Panel for Serious Crimes in East Timor and the Extraordinary Chambers in the Courts of Cambodia (ECCC). These two were hybrid courts fostered by UN initiative. ${ }^{290}$

\footnotetext{
${ }^{288}$ Scharf, Michael and Margaux Day, "The ad hoc international criminal tribunals: launching a new era of accountability," The Routledge Handbook of International Criminal Law, 58.

${ }^{289}$ Scharf, Michael and Margaux Day, "The ad hoc international criminal tribunals: launching a new era of accountability," The Routledge Handbook of International Criminal Law, 58.

${ }^{290}$ The ECCC was established by an agreement between the UN and the Royal Government of Cambodia in 2003 concerning the Prosecution under Cambodian Law of Crimes committed during the period of the Democratic Kampuchea (ECCC Agreement). The ECCC despite being created by the UN and the government, its operation was set to be independent of them. It is paramount to stress that the ECCC is not an international court, but a Cambodian court with international participation design to apply international standards. The ECCC exercised authority to prosecute "only two categories of alleged perpetrators for alleged crimes committed between 17 April 1975 and 6 January 1979: 1) Senior leaders of Democratic Kampuchea; and 2) Those believed to be most responsible for grave violations of national and international law," (https://www.eccc.gov.kh/en/document/legal/agreement).
} 
My analysis will not include hybrid courts; I am focusing exclusively on criminal courts of an international nature since these are the ones to affect more directly the development of International Criminal Law.

\section{The International Criminal Court}

The International Criminal Court (ICC) is the only permanent international criminal court created by the international community. The ICC "investigates and, where warranted, tries individuals charged with the gravest crimes of concern to the international community: genocide, war crimes and crimes against humanity."291 Established in 2002, the ICC currently has 124 State parties to the Rome Statute. ${ }^{292}$ Its temporal jurisdiction applies from the establishment date onward, and extends to all those State parties.

The ICC operates differently than the UN based ad hoc courts. To begin with, it does not exercise primacy over national courts, the ICC instead has jurisdiction complementary to domestic courts, which means the court will try a case only if the country where the crime occurred, or any other country for the matter, has failed or is unwilling to bring the accused to justice.

The ICC may only bring charges against nationals from a State party, with a few exceptions to this directive, such as when the crime has occurred within a state that is

\footnotetext{
The UN Special Panel for Serious Crimes in East Timor was established by the UN Transitional Administration in East Timor (UNTAET) to try serious criminal offenses that occurred during 1999. The Special Panels operated between the years of 2000 to 2006, http://www.crimesofwar.org/commentary/easttimor-ten-years-on-justice-denied/, Jan. 14. The Special Panel was not a criminal court per se, but part of the process managed by the United Nations of reconstructing and revitalizing the justice system of East Timor.

291 “About the ICC," https://www.icc-cpi.int/about.

292 “About the ICC," https://www.icc-cpi.int/about
} 
party to the ICC; when a case is referred to the ICC Prosecutor by the UN Security

Council. Third, when the nonparty State has consented to have its nationals prosecuted. ${ }^{293}$

\section{The importance of international courts}

International courts ( $a d$ hoc and non-ad hoc) were and are still important for several reasons. First, these courts were created to bring those most responsible for human atrocities (serious violations of International Humanitarian Law and International Human Rights Law) to justice through international mechanisms when national courts were incapable or unwilling to do it, thus, avoiding international impunity, and honoring the victims' rights to justice. Second, regarding jurisprudential legal development, the international courts exercise the role of:

ascertaining the existence and content of customary rules, interpreting and clarifying treaty provisions, and elaborating-according to general principles-legal categories and constructs for the application of international criminal rules. The result is that the rapid development of substantive international criminal law is mainly due to judicial decisions. $^{294}$

Finally, “...many of the core jurisdictional principles and jurisprudence developed by them (international courts in general) will influence decisions of the International Criminal Court, and remain an important subsidiary source of customary international law."295

\footnotetext{
${ }^{293}$ Akade, Dapo, "The Jurisdiction of the International Criminal Court over Nationals of Non- Parties: Legal Basis and Limits," Journal of International Criminal Justice 1 (2003), 618-650, http://www.oxfordjournals.org/our_journals/jicjus/2003award.pdf

${ }^{294}$ Cassese, Antonio, "International Criminal Law.” International Law, ed. Evans (2003), 726.

${ }^{295}$ Sadat, Leila. "Understanding the complexities of international criminal tribunal jurisdiction," The Routledge Handbook of International Criminal Law, eds. Schabas and Bernaz (New York: Routledge, 2011), 206.
} 
So, one can safely conclude from the above remarks that the work of one international court, whether ad hoc or not, can greatly influence the functioning of the others.

A deeper look at the Special Court for Sierra Leone

Following the bloodshed that occurred during Sierra Leone's civil conflict, former President Kabban of Sierra Leone sent a letter dated12 June 2000 to the UN Secretary General requesting UN's assistance in the creation of "a credible court" to try the worst offenders of the Sierra Leone conflict. ${ }^{296}$ As a result, the UN Secretary General persuaded the UN Security Council to adopt Resolution 1315 (2000), which authorized the UN Secretary General to negotiate a bilateral treaty, between the UN and the government of Sierra Leone, for the establishment of such a court. ${ }^{297}$ The negotiations were conducted by the UN Secretary General, with authorization and under scrutiny of the UN Security Council, as well as with guidance/counsel of UN legal advisers. The negotiation resulted in the UN-Sierra Leone Agreement and its annexed Statute which received the last UN Security Council approval before it was signed by the UN Secretary General and Sierra Leone in January $2002 .^{298}$

The Court operated from 16 January 2002 to 26 September 2013. September 2013 marked the date of the court's final ruling delivered by the Appeals Chamber upholding a

\footnotetext{
${ }^{296}$ See UN Doc. S12000786 cited by Jalloh, Consolidated Legal Texts for the Special Court for Sierra Leone, 170.

297 Jalloh, Consolidated Legal Texts for the Special Court for Sierra Leone, 170.

298 Jalloh, Consolidated Legal Texts for the Special Court for Sierra Leone, 170.
} 
50-year sentence to former Liberian President Charles Taylor. ${ }^{299}$ Taylor had been found guilty in April 2012 of five counts of crimes against humanity, five counts of war crimes and one count of other serious violations of international humanitarian law perpetrated by Sierra Leone's Revolutionary United Front (RUF) rebels, who he supported. ${ }^{300}$

The SCSL as its predecessors, the IMT, the Tokyo Tribunal, the ICTY, and ICTR, all exercised the power to determine their own jurisdiction. "This power, known as the principle of 'Kompetenz-Kompetenz' in German or 'la compétence de la compétence' in French, is part, and indeed a major part, of the incidental or inherent jurisdiction of any judicial or arbitral tribunal, consisting of the 'jurisdiction to determine its jurisdiction', as stated by the SCSL Appeals Chamber" following the ICTY Tadić decisions. ${ }^{301}$ In other words, The SCSL “....is empowered to pronounce on the validity and legality of its creation." 302

The jurisdiction of the SCSL was directed toward the prosecution of persons who "bear the greatest responsibility for serious violations of international humanitarian law and Sierra Leonean law committed in the territory of Sierra Leone since 30 November 1996, including those leaders who, in committing such crimes, have threatened the establishment of and implementation of the peace process in Sierra Leone." ${ }^{\text {303 }}$

\footnotetext{
${ }^{299}$ Gberie, Lansana, "The Special Court for Sierra Leone rests - for good," Africa Renewal (2014), http://www.un.org/africarenewal/magazine/april-2014/special-court-sierra-leone-rests---good

${ }^{300}$ Gberie, Lansana, "The Special Court for Sierra Leone rests - for good,” Africa Renewal (2014), http://www.un.org/africarenewal/magazine/april-2014/special-court-sierra-leone-rests---good

${ }^{301}$ Prosecutor vs. Dusko Tadic a/k/a "Dule", Decision on the Defence Motion for Interlocutory Appeal on Jurisdiction (ICTY, October 2, 1995), www.icty.org/x/cases/tadic/acdec/en/51002.htm

${ }^{302}$ Schabas, The UN International Criminal Tribunals: The Former Yugoslavia, Rwanda, and Sierra Leone, 51.

${ }^{303}$ SCSL Statute, Article 1.
} 
Unlike the ICTY and ICTR, which were created as subsidiary organs of the UN under Chapter VII of the Charter, the SCSL followed a design inaugurated by the IMT, that is, it was created by an international treaty, between the UN and the government of Sierra Leone. ${ }^{304}$ The SCSL was negotiated between the UN and the Government of Sierra Leone, which makes this Court the first criminal tribunal to be established by an agreement between the UN and one of its Member states. ${ }^{305}$ The Appeals Chamber of the SCSL has affirmed the agreement between the United Nations and Sierra Leone as one operative 'between all members of the United Nations and Sierra Leone' making it 'an expression of the will of the international community. ${ }^{306}$ What does it mean, in terms of treaty obligations, to have the UN as one of the parties to a bi-lateral treaty? Would this mean that the obligations derived from the treaty would also apply to all the UN members? That would appear to be the case, however, this idea raises uncertainties and is not bound by the rules of the Vienna Convention on the Law of Treaties. As expressed by Articles $34-36$ of the Vienna Convention on the Law of Treaties, treaties do not create obligations to third parties. Meaning only those who have consented to be bound by a treaty are expected to follow its provisions. One exception is treaties that were concluded via a UNSC resolution based on Chapter VII, as was the case with the Statutes of the ICTY and the ICTR. In this case, the obligation for compliance extends to all State members (of the $\mathrm{UN}$ ).

\footnotetext{
${ }^{304}$ Jalloh, Consolidated Legal Texts for the Special Court for Sierra Leone, 172.

${ }^{305}$ Jalloh, Consolidated Legal Texts for the Special Court for Sierra Leone, 171-2.

${ }^{306}$ Schabas, The UN International Criminal Tribunals: The Former Yugoslavia, Rwanda, and Sierra Leone, 60.
} 
But if this is not the case, as it was not with the SCSL, then what does it mean, in practical terms, for the UN to be one of the parties to the treaty? I am not certain that there is an answer to this question yet.

That being said, having the UN as one of the parties to a treaty certainly offers a greater level of political legitimacy (for more info see the work of Inis Claude, 1966) and legal validity since the UN has defined as one of its central roles, as established by the General Assembly, the development and promotion of international law. ${ }^{307}$ For this task, the Assembly created in 1948 the International Law Commission (ILC) aimed at promoting "the progressive development of international law and its codification." (Article 1 of the Statute of the International Criminal Law). 'Progressive development' is defined as "the preparation of draft conventions on subjects which have not yet been regulated by international law or in regard to which the law has not yet been sufficiently developed in the practice of States" and 'codification' as "the more precise formulation and systematization of rules of international law in fields where there already has been extensive State practice, precedent and doctrine" (Article 15 of the International Criminal Law Statute). ${ }^{308}$

Another factor which brings legitimacy to the SCSL is the "high level of involvement of the Security Council in the in the establishment of the court included, but not limited to, approving the Statute of the Special Court and initiating and facilitating

\footnotetext{
${ }^{307}$ Claude, L. Inis, "Collective Legitimization as a Political Function of the United Nations", International Organizations (1966).

308 "About the Commission, Organization: programme and methods of work": International Law Commission, http://legal.un.org/ilc/work.shtml).
} 
arrangements for the funding of the Court." ${ }^{309}$ Schabas (2006) has argued that despite the SCSL not being a UN Security Council subsidiary organ, the Council exercised immense influence on its creation and operation. The Council explicitly authorized the creation of the SCSL by Resolution 1315, and was directly involved in the drafting of the Statute of the court. In exchange communications between the UN Secretary General and the Security Council, the Council set its preferences for certain parts of the Statute and on every point, the view of the Council prevailed. ${ }^{310}$ Finally, the Security Council authorized the draft that became the final version of the Statute. ${ }^{311}$

How international criminal courts operate

International courts are bound per excellence only by international law as explained by ICTY Judge Cassese. In reference to the ICTY Cassese expresses that: "This International Tribunal is called upon to apply international law, in particular, our Statute and principles and rules of international humanitarian law and international criminal law. Our International Tribunal is a court of law; it is bound only by international law. ‘312

\footnotetext{
${ }^{309}$ Schabas, The UN International Criminal Tribunals: The Former Yugoslavia, Rwanda, and Sierra Leone, 55 about Taylor, Decision on Immunity from Jurisdiction para. 37 (ICTY 21 May 2004).

${ }^{310}$ Schabas, The UN International Criminal Tribunals: The Former Yugoslavia, Rwanda, and Sierra Leone, 56.

${ }^{311}$ Schabas, The UN International Criminal Tribunals: The Former Yugoslavia, Rwanda, and Sierra Leone, 56.

${ }^{312}$ Erdemovic, Separate and Dissenting Opinion of Judge Cassese, para. 11(ii) (ICTY, 7 October 1997).
} 
Domestic law may be used by international courts when the court finds that the "applicable law instruments are inadequate for the solution of legal problems." ${ }^{.313}$ All three UN based ad hoc courts (ICTY, ICTR, and SCSL) have Statutes that "make specific reference to the possible application of the national criminal law of the State where the crime was committed. In the case of the ICTY and ICTR, this occurs in the sentencing provisions, while in the SCSL Statute national law is given a more prominent role...incorporating some offenses drawn from the national law." ${ }^{314}$

The Special Court officially functions with a "mixed jurisdiction and composition format" ${ }^{315}$ (ratione materiae jurisdiction), which means "the Prosecutor could invoke either or both international and Sierra Leonean law to prosecute offenders." ${ }^{316}$ In fact, domestic law may be used when the court finds that the "applicable law instruments are inadequate for the solution of legal problems." ${ }^{317}$ Despite the Special Court exhibiting some national features, it is recognized and treated as a UN-established international court: "a creature of international law, not domestic law"318 and “...independent of Sierra Leonean courts and possessing the distinct legal personality of an international

\footnotetext{
${ }^{313}$ Schabas, The UN International Criminal Tribunals: The Former Yugoslavia, Rwanda, and Sierra Leone, 74 .

${ }^{314}$ Schabas, The UN International Criminal Tribunals: The Former Yugoslavia, Rwanda, and Sierra Leone, 74.

315 "Report of the Secretary-General on the Establishment of a Special Court for Sierra Leone", UN Doc. S/2000/915, para. 9 .

316 Jalloh, Consolidated Legal Texts for the Special Court for Sierra Leone, 172.

${ }^{317}$ Schabas, The UN International Criminal Tribunals: The Former Yugoslavia, Rwanda, and Sierra Leone, 74.

${ }^{318}$ Schabas, The UN International Criminal Tribunals: The Former Yugoslavia, Rwanda, and Sierra Leone, 74.
} 
organization that permits it to operate in the sphere of international law." ${ }^{319}$ Being labeled an international court meant the SCSL was an independent court, created by international law and operating under international law, as determined by the Ratification Act of 2002 (signed by the Parliament of Sierra Leone). ${ }^{320}$

\section{Sources of law of the international courts}

The principal legal instrument of all three ad hoc tribunals is the Statute, followed by the Rules of Procedure and Evidence (RPE). ${ }^{321}$ The Statute spells out the structure, the current law under which the court will follow, and the jurisdiction and limitations of the international courts. It functions similarly to setting down the operational "rules of the game," while the RPE sets the procedural rules of how the court is to operate.

When the Statutes [or the Rules of Procedure and Evidence] do not provide appropriate legal answers to cases, the Courts may exercise the liberty of diverting from these instruments in the interest of justice, and / or more commonly, the Tribunals have acted as if there were a provision in the statutes inviting them to apply customary law as residual law. ${ }^{322}$ The reason the drafters of the Statutes of international Tribunals attributed

\footnotetext{
${ }^{319}$ SCSL Ratification Act 2002.

${ }^{320}$ Ratification Act of 2002 was established that the SCSL is not part of the Judiciary of Sierra Leone and the offenses prosecuted by the Special Court are not prosecuted the name of the Republic of Sierra Leone Articles 11 (2) and 13 of the Ratification Act 2002.

${ }^{321}$ Schabas, The UN International Criminal Tribunals: The Former Yugoslavia, Rwanda, and Sierra Leone, 76.

${ }^{322}$ Schabas 2006, The UN International Criminal Tribunals: The Former Yugoslavia, Rwanda, and Sierra Leone, 75. International customary law is also utilized by international courts "in the absence of a specific privilege granted by the Rules and the Statute." (97) And when no customary law is found and no treaty law exists to enlighten the course of international law "international and national criminal courts may draw upon general principles of criminal law as they derive from the convergence of the principal penal systems of the world... to fill any lacunae in the Statute of the International Tribunal and customary law." (103) Kupreski'c, para. 677, (ICTY, 14 January 2000 cited in Schabas, The UN International Criminal Tribunals: The Former Yugoslavia, Rwanda, and Sierra Leone, 2006, 75) Important to mention that general principles
} 
international customary law a place as residual law is to avoid violating the principle of nullum crimen sine lege or principle of legality if a party to the conflict has not adhere to a specific treaty. ${ }^{323}$ The principle of legality holds that no one can be considered guilty of a crime if their act or omission was not considered a penal offense under the referent legal system at the time it was committed. ${ }^{324}$

As an illustration of how customary law is recognized as a predominant source of law is the ICTR Appeals Chamber's affirmation that " $[\mathrm{t}]$ he International Tribunal is...governed by its own Statute and by the provisions of customary international law, where these can be discerned.",325

Perhaps the most significant concerns of the international Courts is to reinforce their compliance with the principle of legality through the use of customary law when applying and interpreting their Statutes, because all three tribunals exercise jurisdiction over crimes committed before their establishment, as well as prospectively. When the ICTY Statute was drafted, the Secretary-General and the Security Council sought to avoid potential challenges of not confirming with the principle of legality and made explicit that the Tribunal's subject-matter jurisdiction to offenses was "beyond any doubt

of criminal law are also the foundation for criminal defenses the defenses of international criminal law such as-such as minimum age or mental incapacity, drawing upon general principles of law recognized by all nations.' (Schabas, The UN International Criminal Tribunals: The Former Yugoslavia, Rwanda, and Sierra Leone, 2006, 104).

${ }^{323}$ United Nations Security Council, "Report of the Secretary-General on the Establishment of a Special Court for Sierra Leone" (October 4, 2000), para. 34, http://daccess-ddsny.un.org/doc/UNDOC/GEN/N00/661/77/PDF/N0066177.pdf?OpenElement.

${ }^{324}$ Schabas, The UN International Criminal Tribunals: The Former Yugoslavia, Rwanda, and Sierra Leone, 61.

${ }^{325}$ Barayagwiza Decision (Prosecutor's Request for Review or Reconsideration) (31 March 2000) cited in Schabas, The UN International Criminal Tribunals: The Former Yugoslavia, Rwanda, and Sierra Leone, 75,76 . 
part of customary law so that the problem of adherence of some but not all States to specific conventions does not arise." ${ }^{, 326}$ In Schabas' opinion "the statement made by the Secretary-General's Report to the Security Council ${ }^{327}$ has been used to justify what amounts to an interpretative presumption regarding the relationship between the principle of legality and customary law. Next, Schabas cites a pronouncement by by the ICTY Appeals Chamber: ${ }^{328}$

“...in case of doubt and whenever the contrary is not apparent from the text of a statutory or treaty provision, such a provision must be interpreted in light of, and in conformity with, customary international law. In the case of the Statute, it must be presumed that the Security Council, where it did not explicitly or implicitly depart from general rules of international law, intended to remain within the confines of such rules. ${ }^{\text {(329 }}$

Customary law is also fundamental when determining which crimes fall within the jurisdiction of the Court for the same reason of staying in compliance with the principle of legality. The UN Secretary General stated quite clearly in his report on the establishment of the ICTY, that the Tribunal would only be able to prosecute offenses

\footnotetext{
326 "Report of the Secretary-General under Paragraph 2 of Security Council Resolution 808 (1993)", UN Doc. S/25704 (1993), para. 34.

327 "Report of the Secretary-General under Paragraph 2 of Security Council Resolution 808 (1993)", UN Doc. S/25704 (1993), para. 34.

${ }^{328}$ Schabas, The UN International Criminal Tribunals: The Former Yugoslavia, Rwanda, and Sierra Leone, 83 .

${ }^{329}$ Tadic, Judgment, para. 287 and para. 296 (15 July 1999) cited by Schabas, The UN International Criminal Tribunals: The Former Yugoslavia, Rwanda, and Sierra Leone, 83.
} 
that were unquestionably recognized as customary international law: ${ }^{330}$ "the International Tribunal only has jurisdiction over offenses that constituted crimes under customary international law at the time the alleged offenses were committed" as previously stipulated by one of the Trial Chamber of the ICTY. ${ }^{331}$ One again, the ICTY Chamber clarified that "the only reason behind the stated purpose of the drafters that the International Tribunal should apply customary international law was to avoid violating the principle of nullum crimen sine lege if a party to the conflict did not adhere to a specific treaty.",332

Keeping conformity with international customs is also the rule when a certain provision of the Statute requires clarification. If the judges were to conclude that a specific provision in the Statute was inconsistent with existing customary international law "such that the discrepancy could not be resolved by interpretation, they would have no choice but to declare the impugned provision to be inoperative."333

Leading us to conclude that international customary law is an essential guide when creating and operating any international court; it guides the development of Statutes and Rules of Procedure and Evidence and courts apply customary law as residual law

\footnotetext{
${ }^{330}$ Schabas, The UN International Criminal Tribunals: The Former Yugoslavia, Rwanda, and Sierra Leone, 2006, 61.

${ }^{331}$ Kordi ${ }^{\prime}$ c et al. Decision on the Joint Defence Motion to Dismiss the Amended Indictment for Lack of Jurisdiction Based on the Limited Jurisdictional Reach of Articles 2 and 3, para. 20 (2 March 1999) cited by Schabas, The UN International Criminal Tribunals: The Former Yugoslavia, Rwanda, and Sierra Leone, 84.

${ }^{332}$ Kordi' $c$ et al. Decision on the Joint Defence Motion to Dismiss the Amended Indictment for Lack of Jurisdiction Based on the Limited Jurisdictional Reach of Articles 2 and 3, para. 20 (ICTY 2 March 1999) cited by Schabas, The UN International Criminal Tribunals: The Former Yugoslavia, Rwanda, and Sierra Leone, 84 .

${ }^{333}$ Schabas, The UN International Criminal Tribunals: The Former Yugoslavia, Rwanda, and Sierra Leone, 2006, 84 and 101.
} 
whenever the existing treaty rules do not enlighten or provide guidance on a certain case. Schabas (2006) has taken one step forward supporting the argument, as expressed by most international courts statutes, that the list of crimes under the court's jurisdiction, reflects customary law. Such position has also been affirmed by the Trial Chambers of ICTY: "The ICTY determined that the crimes covered by Articles 2, 3, 4, and 5 of the Tribunal's Statute reflect customary international law. The Blaskić Appeals Chamber, quoting the Hadzihasanović case, stated, in the context of a discussion of nullum crimen sine lege, that "it has always been the approach of this Tribunal not to rely merely on a construction of the Statute to establish the applicable law on criminal responsibility, but to ascertain the state of customary law in force at the time the crimes were committed." ${ }^{\prime 34}$ Overall, if we take a step back, the strategy to affirm conformity with current law, and more specifically customary law has been the strategy used by most international courts past and present.

The claim that international courts has followed international customary law when creating its documents as well as adjudicating its cases is bound to provoke controversy when applied to the provision contained in Article 7(1) of the Statute of the SCSL, which grants the Court authorization to exercise "jurisdiction over persons who were fifteen years of age at the time of the alleged commission of the crime." The rule was written by

\footnotetext{
${ }^{334}$ Scharf and Margaux Day, "The ad hoc international criminal tribunals: launching a new era of accountability," 54. There is a "presumption that provisions of the Statute are consistent with customary law as examined by the ICTY in Tadic, para.296 (ICTY 15 July 1999). In another case, the ICTY expressed that "the inclusion of superior responsibility liability in Article 7(3) of the Statute "should be read as a reflection of the reasonable and well-supported views of the Security Council and the SecretaryGeneral that this norm formed part of customary international law at the time covered by the mandate of the International Tribunal' in Hadz ' ihasanovi' $c$ et al, Decision on Joint Challenge to Jurisdiction, para. 171 (ICTY 12 November 2002) Also see Schabas, The UN International Criminal Tribunals: The Former Yugoslavia, Rwanda, and Sierra Leone, 101.
} 
the UN Secretary General in consultation with the government of Sierra Leone and the UN Security Council, and received the full support of the Security Council. Therefore, Article 7(1) is a product of international law-making coming from the UN Secretary General and the Security Council, and provides a clear indication of the UN's position and where it believes customary law stands on the issue of children's criminal responsibility under international law.

How important was the Special Court's decision to include minors as liable to individual criminal prosecution to the development of international criminal law?

There are two steps when attempting to answer the above question. First, by showing how international courts influence each other's work, in this case, how the SCSL's decision to include children under its jurisdiction serves as guidance for other international courts or for national courts applying international criminal law to do so as well. The second step, which can also be seen as a complement to the first attempt, is to argue that the Statute of the SCSL, which included that children fifteen years of age and older could be brought to the court, is an expression of established international law. This in practical terms means that the decision of the Court to include juveniles can be understood as providing evidence (for other international courts or national courts) of an existing rule of international law on the issue of juvenile justice when minors are accused of serious breaches of International Humanitarian Law and International Human Rights Law.

It is important to mention that despite the level of cooperation and even similarity between international criminal courts -- which is fundamental to the enlargement and refinement of International Criminal Law - these courts are not under an obligation to 
follow the doctrine of precedence. The doctrine of precedence or Stares Decisis: "is a doctrine according to which when a court has once laid down a principle of law as applicable to a certain state of facts, it will adhere to that principle, and apply it to all future cases, where the facts are substantially the same. ${ }^{\$ 335}$ In other words, the doctrine of precedence consists of an authoritative way of legal reasoning and decision making predominantly found in common law systems, in which, an "international judge seems to feel bound by the jurisprudence of another court" or even previous decisions of the same court. ${ }^{336}$ The decision to take into consideration judicial rulings from external other courts is a discretionary practice: courts can choose to do so if they wish, and judicial decisions count as evidence of law, not necessarily as sources of law. However, the use of judicial decisions by international courts has been gaining space in International Criminal Law, as expressed by Terris, Romano, and Swigart in a study conducted in 2007. The authors concluded that international judges, even though they are at liberty to choose their paths of reasoning, have been entertaining the use of other courts' decisions when a lack of precedent is evident. ${ }^{337}$

Seeking guidance from other court's decisions has not been the traditional path set by international courts; this is the reason why the work of Terris, Romano, and Swigart is so revealing. As stated in the Statute of the ICJ, the three main sources utilized by the

\footnotetext{
${ }^{335}$ Kaczorowska, Public International Law, 859.

${ }^{336}$ Terris et al., The international judge: an introduction to the men and women who decide the world's cases (Oxford: Oxford University Press, 2007), 120.

${ }^{337}$ Terris et al., The international judge: an introduction to the men and women who decide the world's cases (Oxford: Oxford University Press, 2007), 120.
} 
court are: treaties, customary law, and general principles of law. If no law on the matter in question can be found in these three sources, then the court may utilize previous judicial decisions and the writings of jurists as evidence of the law, or divert from the sources and decide ex aequo et bono (from equity and goodness), if the parties agree. The list and explanation of the sources of International Law sources are found in chapter two of the present dissertation.

The sources of international law utilized by the ICC and the various tribunals differ somewhat from the ICJ's list, and include first, to be given precedence over the others: The Statute, followed by the Elements of Crimes and the Rules of Procedure and Evidence. If legal guidance on the issue at hand is not to be found within these sources, then "the second tier in the hierarchy of sources consists of applicable treaties and the principles and rules of international law, including the established principles of the international law of armed conflict." ${ }^{338}$ According to Schabas, "this second tier in the hierarchy of sources corresponds to the sources of international law as set out in Article 38 of the Statute of the International Court of Justice, although the wording is quite original. ${ }^{, 339}$ It is only with the ICJ's source list that one will find 'judicial decisions' listed as a source of international law.

We can also identify international courts' cooperation in the statement given by the ICTY Trial Chambers about the court's legal sources:

The primary sources on which the ICTY relies are other decisions of the ICTY and decisions of the Rwanda Tribunal, with an emphasis on

\footnotetext{
${ }^{338}$ Schabas, The International Criminal Court: A Commentary on the Rome Statute, 2007, 195.

${ }^{339}$ Schabas, The International Criminal Court: A Commentary on the Rome Statute, 2007, 195-6.
} 
Appeals Chamber decisions. As a secondary source, the ICTY may be 'guided by the case-law of the Nuremberg and Tokyo Tribunals, the tribunals established under Allied Control Council Law No. 10, and the Tribunal for East Timor. ${ }^{340}$ Furthermore, the ICTY may apply customary international law, and it may apply treaty law, so long as the treaty '(i) was unquestionably binding on the parties at the time of the alleged offense; and (ii) was not in conflict with or derogating from peremptory norms of international law, as are most customary rules of international humanitarian law. ${ }^{341}$ When applying treaties, the ICTY recognized that it should interpret conventions in conformity with Articles 31 and 32 of the Vienna Convention on the Law of Treaties. ${ }^{342}$ So, the ICTY main sources for deciding its cases emanate from the ICTY itself, and other international courts, as well as from customary law. ${ }^{343}$

Another indication of how the ICTY and ICTR can make a "significant contribution to the general corpus of international criminal law is expressed in Article 20(3) of the Special Court of Sierra Leone's Statute which allows the court to be guided by the decisions of the joint ICTY/ICTR Appeals Chamber. ${ }^{344}$ The article stipulates that: "the judges of the Appeals Chamber of the Special Court shall be guided by the decisions of the Appeals Chamber of the International Tribunals for the former Yugoslavia and Rwanda. In the interpretation and application of the laws of Sierra Leone, they shall be guided by the decisions of the Supreme Court of Sierra Leone." 345 In Cryer's words, "the

\footnotetext{
${ }^{340}$ Stakic, Trial Chamber, para. 414 (ICTY 31 July 2003) cited by Scharf and Margaux Day, The ad hoc international criminal tribunals: launching a new era of accountability," 54.

${ }^{341}$ Galic, Trial Chamber, para. 98 (ICTY 5 December 2003) cited by Scharf and Margaux Day, The ad hoc international criminal tribunals: launching a new era of accountability, "54.

${ }^{342}$ Galic, Trial Chamber, para. 91 (ICTY 5 December 2003); Stakic, Trial Chamber, para. 411 (ICTY, 31 July 2003) cited by Scharf and Margaux Day, The ad hoc international criminal tribunals: launching a new era of accountability," 54.

${ }^{343}$ Scharf and Margaux Day, "The ad hoc international criminal tribunals: launching a new era of accountability," 54.

${ }^{344}$ Cryer, Robert, Prosecuting International Crimes: Selectivity and the International Criminal Law Regime (Cambridge: Cambridge University Press, 2005), 170.

${ }^{345}$ Article 20(3) of the Statute of the SCSL.
} 
Special Court "will apply the decisions of the ICTY and ICTR for their persuasive value, with necessary modifications and adaptations, taking into account the particular circumstances of the Special Court." ${ }^{346}$

In addition, as a rule, international courts have been profoundly influenced by their predecessors ${ }^{347}$ : the ICTY was highly influenced by the Statute and the workings of the Nuremberg Tribunal, which also determined how the Tokyo Tribunal would operate. And when developing the Statute of the ICTR, the UNSC largely adopted the text of the Statute of the ICTY (with a few minor differences regarding the scope of jurisdiction), acknowledging the proximity of these two international courts. ${ }^{348}$

After having established that Statutes and the case law of one court exercises significant influence on the work of other international courts, it is safe to affirm that the SCSL decision to include children starting at age fifteen under its jurisdiction should not be seen differently; it is thus evidence of law on the issue, and invites other courts to adopt this position if they wish. So, even though applying past decisions are not legally required in IL, following the rulings and jurisdictional decisions of other international courts (or even the same court) may be the most efficient way of identify where the law if any -stands, thus avoiding non liquet (a situation in which the law on the issue is not clear, preventing the court from ruling).

\footnotetext{
${ }^{346}$ Cryer, Robert, Prosecuting International Crimes: Selectivity and the International Criminal Law Regime (Cambridge: Cambridge University Press, 2005), 170.

${ }^{348}$ Schabas, The UN International Criminal Tribunals: The Former Yugoslavia, Rwanda, and Sierra Leone, 30-31.
} 
Another possible reason why legal precedent can serve as guidance with regard to existing law in international criminal law (in this case, differently than in the doctrine of State International Responsibility as framed by International Law) is that in international criminal law, the same obligations apply to all individuals. All individuals carry the obligation of following International Humanitarian Law, and any serious violation may give rise to individual criminal responsibility.

Why fifteen was the chosen age by the UN Secretary General to act as the MACR in the Statute of the SCSL?

We have seen that international customary law, as codified in Additional Protocols I and II, as well as by Article 38 of the CRC, sets the minimum age of legal recruitment (MALR) at fifteen. Below fifteen, international law criminalizes the practice of recruiting and using children in combat, however, in the child is fifteen or older, he/she according to customary international law, can legally be recruited and used in hostilities. The Special Court for Sierra Leone has followed the legal provisions set by International Humanitarian Law conventions when setting fifteen as the minimum age of criminal responsibility (MACR) in its Statute. Happold argued the choice of age made by the UN Secretary General as “mirroring” previous customary International Humanitarian Law rules, such as Articles 77 of Additional Protocol I and Part 4 of Additional Protocol II, as well as, Article 38 of the $\mathrm{CRC}$ provisions "on the ground that if children under fifteen are too young to be recruited, they must be too young to be held responsible for their actions. ${ }^{349}$

\footnotetext{
${ }^{349}$ Happold, "The Age of Criminal Responsibility for International Crimes Under International Law," 10.
} 
As a conclusion, I suggest that the decision of the UN Secretary General, approved by the UN Security Council, to set the MACR for the SCSL was based on the MALR set by international humanitarian law.

Concluding remarks on the jurisprudential contributions of the SCSL applicable to the debate on children's criminal responsibility in international criminal law

The first contribution of the SCSL to the debate on children's criminal responsibility under IL was the court's establishment of a minimum age of criminal responsibility set at fifteen years of age. Granting the SCSL the competence to bring to justice those starting at age fifteen is equivalent to saying that fifteen is the MACR operational under the jurisdiction of the SCSL: "the United Nations specified fifteen as the age of criminal responsibility in the Statute of the Special Court for Sierra Leone.”350 Fifteen was the considered by the UN Secretary General and the UN Security Council as the age by which minors already possess a general understanding of the criminal laws as well as the legal competence to be held responsible for any violations. ${ }^{351}$ Because the SCSL is per excellence an international court, and international courts influence each other, this provision may be used by other courts, international or national, as legal evidence of law when seeking to bring those age fifteen or above to justice when accused of serious breaches of International Humanitarian Law.

The argument that international law has allowed for the creation of an evidence of law which allows for courts to bring individuals starting at age fifteen to trial was

\footnotetext{
${ }^{350}$ Schabas, “Article 26," The International Criminal Court: A Commentary on the Rome Statute (2010), 443.

${ }^{351}$ For more on competence as criteria for individual criminal responsibility see Duff, Answering for Crime: Responsibility and Liability in the Criminal Law, 2007.
} 
reinforced by an International Criminal Tribunal for the Former Yugoslavia (ICTY) Trial Chamber ruling in 2006 which established that was 'no rule in convention or customary international law against criminal liability for a war crime committed by an individual below the age of 18 existed. ${ }^{352}$ Therefore, nothing in IL forbids a child from being held criminally responsible for breaches of IL. If though, the confirmation comes in a negative form: no rule in IL forbids prosecution of persons under eighteen, we can consider this an important yet timid step towards the acknowledgment of a rule set by the Statute of the SCSL.

The second contribution of the SCSL is possibly the most important. The UN Secretary General and UN Security Council decision, reflected in the SCSL's Statute, to include persons fifteen and over, can be interpreted as an expression of court stating that juveniles starting at age fifteen, are capable of committing international crimes, and thus are to be regarded, at least, a priori as viable subjects of international criminal law (emphasis added).

To consider someone or some entity as a subject in IL, it must first be established that the individual or entity has rights and responsibilities within the referent legal system. If they do not, then there are no individual obligations that can be breached, and the individual cannot be deemed responsible. Having a "legal personality" within a legal system entails rights, and in return means bearing certain responsibilities under the legal

\footnotetext{
352 Oric, para. 40 (ICTY 30 June 2006) cited by Schabas, “Article 26”, The International Criminal Court: A Commentary on the Rome Statute (2010), 444-5, footnote 13.
} 
system that empowers them. ${ }^{353}$ If these obligations are not met, they affect other legal subjects, and give rise to a system of accountability, in this case, criminal accountability since the laws breached were international criminal rules. The following chapter will extend on the concept of legal personality and the importance of being considered a subject of a legal-political system.

${ }^{353}$ Crawford, and Simon Olleson, "The Nature and Forms of International Responsibility." In International Law, 442. 
Chapter 8: Final remarks on the presumed legal competence of children at the age of fifteen and over and individual criminal responsibility

Chapter eight is composed of a brief exposition of the concept of legal personality as it is conceived and utilized in International Law. The illustration serves the purpose of reinforcing the conclusion reached in the previous chapter which points to the Statute of the Special Court for Sierra Leone as the first evidence of existing law attributing the status of subject of international criminal law to minors involved in serious breaches of International Humanitarian Law starting at age fifteen. Next, the chapter will present a section I believe to be an essential complement to further the discussion of the legal competence of children as framed by existing international law and criminal responsibility. This second part of the chapter has been developed to guide future research on the topic.

\section{Legal Personality in International Law}

Asking about legal personality is inquiring whether an entity holds some form of standing or status within a legal system; in other words, it is asking whether the entity is "somebody" in that particular normative system. "The importance of an entity being recognized as a subject of international law is that without international legal personality it does not exist in international law, i.e. its acts will not be recognized in international law..."354

A subject of international law, or an entity holding international legal personality, holds rights and obligations under international law, besides having the capacity to "act"

\footnotetext{
${ }^{354}$ Kaczorowska, Public International Law, 82.
} 
within that legal system, for example, to enter into legal relationships, such as undertaking legal obligations, or bringing claims on their behalf (or other entities behalf) to assure that their rights and entitlements are not being infringed by others. ${ }^{355}$ And "apart from the legal considerations, when an entity is regarded a subject of international law, it is granted political recognition from other subjects of international law" as a somebody in the present system. ${ }^{356}$ In other words, having legal personality provides a sense of existence within the international legal system, which affects how others acknowledge and treat you.

Those that "exist" within a legal system are granted rights, and in return, they also hold certain responsibilities: "Being a subject of any legal system involves being subject to responsibilities as well as enjoying rights. ${ }^{.357}$ If these obligations are not met, they affect other legal subjects, and give rise to a system of accountability. The system of accountability in international law is called international responsibility. To recap, only those who have obligations in the first place as a consequence of being a subject of the system, hold the capacity to violate these obligations, and thus generating a system of accountability and responsibility.

Inquiring whether children can be considered subjects of international law should anticipate the question of individual responsibility. In other words, it does not make sense to engage in a discussion of responsibility before one is certain if the entity in question has obligations to fulfill within the legal system in the first place. The rationale is that one

\footnotetext{
${ }^{355}$ Kaczorowska, Public International Law, 176.

${ }^{356}$ Kaczorowska, Public International Law, 182.

${ }^{357}$ Crawford and Olleson, The Nature and Forms of International Responsibility, 442.
} 
must be entitled to obligations before one can violate them and be held responsible for these violations. If the person has no obligations, there is nothing to be made legally accountable for. That being said, the inquiry regarding whether children hold international obligations under international law (as adults do) even though very rarely addressed in the literature (if dealt with at all), should be addressed first, precisely because, in International Law, legal personality is directly related and a pre-requisite of international responsibility.

\section{States as primary subjects and the place of the individual}

Traditionally, states were the only subjects of the international legal system. "[T]hey alone had the capacity to make claims on the international plane in respect of breaches of international law, capacity to make treaties and other binding international agreements, and the ability to enjoy privileges and immunities from national

jurisdiction. ${ }^{, 358}$ states remain are still the main subjects of the law. Yet in the last century, more entities actively participating in the making of international relations were considered making the legal personality list, such as international organizations and individuals.

The state, and some state-like entities, are still the one with full legal personality, while the other entities are considered by most to be "partial" subjects of or "participants" in international law.

\footnotetext{
${ }^{358}$ Kaczorowska, Public International Law, 176.
} 
This configuration reflects the dominant view that international law is still a largely State-based system, in which the participation of other subjects varies widely depending on the consent of states. ${ }^{359}$

As we can notice, not all subjects of international law are the same, that is, they do not have the same legal standing. This was confirmed by the ICJ in its Advisory Opinion on the Reparation for Injuries Suffered in the Service of the United Nations in which the Court held the opinion that: "subjects of law in any legal system are not necessarily identical in their nature or in the extent of their rights' which allowed the court to make a "...distinction between partial and full legal personality." 360

The trajectory of individuals in international law is quite interesting. Traditionally, the actions of individuals did not give rise to any international responsibility on them; "international responsibility only applied when the actions of individuals were attributed to the State, and the State was internationally responsible." ${ }^{361}$ Currently, individuals, as framed by most jurists, are considered "partial" subjects of IL. The partial character is explained by them having obligations directly placed upon them by IL (International Humanitarian Law and International Human Rights Law more specifically), while at the same time, the creation and enforcement of their rights is still largely dependent upon action and the political will of the states. Individuals in rare instances are legally capable representing themselves before international tribunals, they

\footnotetext{
${ }^{359}$ McCorquodale, Robert, "The Individual and the International Legal System," International Law, ed. Malcolm Shaw (Oxford and New York: Oxford University Press, 2010), 288.

${ }^{360}$ Reparation of Injuries Suffered in Service of the U.N., Advisory Opinion, 174 (ICJ Apr. 11, 1949) found in https://h2o.law.harvard.edu/collages/41680.

${ }^{361}$ McCorquodale, “The Individual and the International Legal System," International Law, 291.
} 
are contingent on states developing and enforcing their human rights - as well as the need to initiate and participate on claim against another State accused of violating his or her human right. In arrangements in which the individual has direct access to regional and international courts to bring a claim against a state, the claims must need to go through the domestic justice mechanism first (what it called exhaust domestic legal remedies) before it claim can be considered at the regional or international level.

Individuals, therefore, can be characterized as holding a "handicapped status" in International Law as described by Judge Higgins: for once they have direct criminal responsibility imposed on them for violations of treaty and customary law, but still largely need the State to fully guarantee the creation, as well as, the observance and protection of their human rights. Individuals are also dependent on the State when it comes to seeking justice for a human rights violation, thus needing to file claims / opening juridical processes in international courts.

Moreover, in terms of international obligations, individuals have legal requirements placed directly onto them by International Human Rights Law and International Humanitarian Law, which means, that all persons are subjected to a set of uniform duties emanating from these legal regimes, and in case of serious breach of these duties, courts (domestic or international) may hold them personally and directly accountable.

if individuals - mainly understood as, adults with full societal citizenship, are considered 'partial,' 'incomplete,' or even 'handicapped' subjects of international law, then what can be said of children? Children are mostly understood as 'non-adults, adults in the making, still not equipped with moral, psychological and physical capacities of an 
adult, yet they are still considered an individual, a person, just not one fully sui juris.

Answering the question about the legal personality of children requires a more elaborated analysis of whether children have the same "rights" and "obligations" under IL as adults. We know that children hold international rights. The main example of international children's rights is the Convention on the Rights of the Child. In this convention, children are granted the traditional types of rights - protective rights - rights that assure that their interests are taken into consideration, while still being represented by adults, as well as more novel participation/liberty rights. These novel types of rights act of fulfilling the purpose of which is to guarantee that every child has an active voice regarding their life and their development. As expressed by UNICEF: "Children are entitled to the freedom to express opinions and to have a say in matters affecting their social, economic, religious, cultural and political life. Participation rights include the right to express opinions and be heard, the right to information and freedom of association. Engaging these rights as they mature helps children bring about the realization of all their rights and prepares them for an active role in society." ${ }^{, 362}$

Children also carry obligations like adults. For instance, all children are obligated to follow International Humanitarian Law in times of conflict, as well as to not infringe other people's internationally guaranteed rights. In fact, these obligations, emanating from International Human Rights Law and International Humanitarian Rights are addressed to all individuals including children (despite not having found data on the

\footnotetext{
362 "Rights under the Convention on the Rights of the Child", UNICEF: https://www.unicef.org/crc/index 30177.html.
} 
issue). Someone holding rights and obligations under a legal system is to be considered a subject (even though partial) of that legal system. So, it is safe to conclude that the status of the individual as person in international law would also include those under the age of eighteen.

\section{Tadros' concept of status-responsibility}

Inquiring about the legal responsibility of children is also inquiring about the status of children within the international criminal system. When we talk about the individual holding the capacity to be bound by a legal system, we are qualifying the individual as someone who is a subject of the criminal system. For Tadros, the question of who is a responsible agent as far as the criminal law is concerned is a question of status, and he calls this "status-responsibility." ${ }^{, 363}$ In Tadros' analysis, being capable of holding status-responsibility in the criminal system is equivalent to being considered a viable target of the criminal laws. When inquiring about whether the object in question is capable of holding status responsibility, Tadros is interested in determining whether the individual is capable of understanding norms in general. Tadros, therefore, is not asking if the individual in question is necessarily capable of committing a particular act. ${ }^{364}$ "Capacity plays a role assessing status-responsibility, but that is capacity in the general sense rather than capacity to do, think, feel or evaluate differently from the way in which one does." 365

\footnotetext{
${ }^{363}$ Tadros, Criminal Responsibility (Oxford: Oxford University Press, 2005), 21.

${ }^{364}$ Tadros, Criminal Responsibility, 46.

${ }^{365}$ Tadros, Criminal Responsibility, 61.
} 
Logically, if one is not capable of exercising competence in general, that individual ought to be excluded from criminal responsibility, even if the actus reus conditions of a criminal offense were fulfilled. ${ }^{366}$

In the penal laws of most legal systems, international criminal law included, a person is only to be held culpable and, consequently, punishable, if his or her behavior contains two necessary requirements: a wrongful act (actus reus) and a guilty mind (mens rea). These two requirements need to be present for the construction of the concept of "crime" in criminal law. "To be guilty of a crime, particularly about serious offenses, it is not enough simply to have done a particular prohibited act; there must also be the element of a guilty mind." ${ }^{367}$ If the element of mens rea (guilty mind) is absent, then it is possible that the person may be excused from criminal responsibility. With children, the lack of mens rea is mainly presumed (defense of infancy), and, children may escape criminal liability for their acts. When a minor is brought to trial, it falls to the prosecution "to establish by evidence or informed admission that the child defendant had sufficient understanding of the nature of the offense. ${ }^{368}$ So, determining whether a child meets the requirement of mens rea is largely case-specific and context-dependent, thus better set on a case-by-case basis.

However, the above discussion addressing the criteria for determining guilt for a particular act is not the same as inquiring broadly about the viability and requirements of

\footnotetext{
${ }^{366}$ Tadros, Criminal Responsibility, 21.

${ }^{367}$ Happold, “The Age of Criminal Responsibility for International Crimes Under International Law,” 2.

${ }^{368}$ Duff, Anthony, "Legal and Moral Responsibility," Philosophy Compass 4.6 (2009), Wiley Online Library, Web, 978.
} 
'legal personality.' The question of whether an individual can be considered a priori a subject of the criminal system must be addressed first.

To ask about Tadro's status-responsibility of the agent (condition to be potentially held responsible in the criminal system) it is not only necessary to prove that the acts constituting a crime were committed. For one to be attributed criminal responsibility, it is essential to establish that the individual who acted or failed to act meets what Tadros calls status-responsibility. Status responsibility is "the aspect of responsibility that an agent requires fulfilling to be held responsible for any of his actions." 369 As such, the inquiry reflects the answer to the question: who is a responsible agent as far as the criminal law is concerned? ${ }^{370}$ As such, the present reflection inquires on the agent's place within the criminal law system, in other words, if the agent to be considered someone who is a viable target of the criminal laws or not?

Duff adds that criminal norms also perform a communicative function, and are aimed at those who have the capacity to understand them: "The criminal law speaks to those whom it claims to bind..." ${ }^{371}$ The same opinion is shared by Tadros: "The criminal law aims to communicate through its norms." 372 This pertains only to those who hold the minimum standards for the law's comprehension.

\footnotetext{
369 Tadros, Criminal Responsibility, 55.

370 Tadros, Criminal Responsibility, 21.

${ }^{371}$ Duff, Answering for Crime: Responsibility and Liability in the Criminal Law, 43.

${ }^{372}$ Duff, Answering for Crime: Responsibility and Liability in the Criminal Law, 43.
} 
To those who do not understand its norms, criminal law remains uncommunicative, and consequently, they cannot be held responsible for the criminal justice system. ${ }^{373}$

Also, the criminal law presents itself not only as a set of coercive threats, but also as a system of moral obligations, standards, and concerns, which demand citizens' obedience. By the same token, citizens who are incapable of appreciating these norms cannot legitimately be subjected to them. ${ }^{374}$ In other words, being able to understand the standards of criminal law at the moment when the criminal offense was committed as well as the time the trial is performed is essential for the attribution of criminal responsibility. $^{375}$

As established in the previous chapter, by including those starting at the age of fifteen under its jurisdiction, the SCSL has made the case for people under the age of eighteen to be considered viable subjects of international penal laws, therefore viable for criminal prosecution if the criteria of mens rea and actus reus are fulfilled. According to the brief analysis here of what it means to be a subject of a legal system, we can conclude that the court has acknowledged (via the works of the UN Secretary General and the Security Council) these children hold the general capacity to understand the international laws by which all persons must abide by.

\section{A note on duress}

I have intentionally not delved into the question of whether children are de facto

\footnotetext{
${ }^{373}$ Horder, Jeremy. "Determinism, Liberalism, and Criminal Law." Current Legal Problems, no. 49 (1996), 167-8.

${ }^{374}$ Tadros, Criminal Responsibility, 136.

${ }^{375}$ Tadros, Criminal Responsibility, 136.
} 
capable of understanding and abiding by the criminal laws currently in place. My exclusive concern is how current international law acknowledges and treats children involved in the commission of serious breaches of humanitarian law. Therefore, the discussion of whether the element of duress - more specifically, whether children recruited and used in military actions have genuinely chosen to do so or they were simply responding to violence or extreme external pressure - can be considered a viable excuse for criminal responsibility is bracketed. The lack of discussion of duress does not necessarily reflect the position of the author finding it less fundamental for the debate on criminal responsibility. And I can even say that in the case of children, framed as less competent decision makers, duress is a viable central excuse of criminal responsibility. However, duress like other possible excuses of individual responsibility such as 'diminished mental capacity', were addressed by the ICC and the ad hoc criminal courts as mitigating factors in the sentencing phase of international criminal cases; therefore, it arises only after it has been established whether the person in question is legally competent to be considered a viable subject of the penal laws and has not excused from criminal responsibility. ${ }^{376}$ For the current work, the question of legal subjectivity is the only concern.

\section{$M A C R$, liberty rights, and legal competence}

A complementary way of assessing whether children are considered a priori

\footnotetext{
${ }^{376}$ Reilly, "Affirmative Defenses in International Criminal Proceedings," Defense Perspectives on International Criminal Justice? 2017, chapter 15.
} 
legally competent to bear individual criminal responsibility for serious breaches of international law requires more elaboration, focusing on the MACR established by the SCSL at age of fifteen which also corresponds to the liberty right given to children by International Humanitarian Law towards early enlistment.

Here, I will simply start the conversation, indicating my intention of continuing the work on future research projects.

Children, from a very early age, due their presumed vulnerability and incapacity for moral reasoning, in most societies, and in international law, children are awarded protection rights:

Protection rights are claims that other people owe some duty to protect vital interests of the right-holder. For instance, the rights to education, health, and physical safety are protection rights, which refer to fundamental interests of all people. The majority viewpoint is that children enjoy protection rights, but that they may or may not be able to exercise liberty rights for themselves depending on the exact context and their capacity in that context. ${ }^{377}$

As children develop and are acknowledged by their society they "progressively acquire liberty rights by passing successive age limits, each denoting legal competency and responsibility in different areas. ${ }^{378}$ Liberty rights are similar to 'adult' rights; they carry a prerogative that the rights holder has achieved enough maturity to be enabled to exercise such rights, and thus, liberty rights entitles the right holder to act with freedom in specific contexts - in the sense that there is no restriction on them - by triggering the duty to others [and the government] not to interfere. Specific

\footnotetext{
${ }^{377}$ Cipriani, Children's Rights and the Minimum Age of Criminal Responsibility: A Global Perspective, 3.

${ }^{378}$ Cipriani, Children's Rights and the Minimum Age of Criminal Responsibility: A Global Perspective, 3.
} 
liberty rights include, for example, the rights to free speech, to freedom of religion, and to vote.

In short, the law prescribes age limits to attest to children's legal competence, and when the child has achieved a certain age that reflects a presumed ability to exercise certain 'adult activities,' such as to marry, drive, drink, it is assumed by society that he or she has attained the maturity necessarily to exercise these activities with responsibility. Lawmakers ultimately encapsulate in one age, at one point in time, in a particular sociopolitical-cultural context, some batch of ideas about children's capabilities and society's expectations about children's appropriate role. According to Cipriani (2009) achieving the age of legal competence "demarcates the onset of a particular liberty right.".

The legal age of competence in the United States, for example, which determines the liberty right to drive is sixteen; to marry is eighteen (with a few exceptions, juveniles age sixteen may engage in marriage with parental consent), to join the army is seventeen with parental consent, eighteen without; to vote is eighteen; to drink is twenty-one.

The younger and (presumably) less competent the child, the more protection rights and the fewer liberty rights are awarded. The reciprocal is also true. The older and more mature the child becomes, legal competence in certain areas is assumed, more liberty rights are given, and fewer protections rights are offered. It is essential to notice that legal competence functions as the intermediary element which measures / presupposes the exercise of liberty rights. As explained by Cipriani:

There is an inverse relationship between the protection rights and liberty... with competency as the pivot point. With less competence, protection rights come to the fore and liberty rights drift to the rear; yet with greater competency, liberty rights take greater prominence. Competence [then] adopts a central role in the predominant rights discourse; an individual 
generally must have the relevant competence to assert a given liberty right for himself or herself. 379

With regard to individual responsibility and liberty rights, Cipriani establishes a direct correspondence between one's attainment of a liberty right and the obligation derived from this right: "to respect and protect a competent individual's choices [which] necessarily assign responsibility for choices and actions back to the individual who makes them." 380

\section{Legal competence and criminal responsibility}

Upon reaching the stipulated age of legal competence "children may potentially bear criminal responsibility for their actions, and the state can first legitimately levy - in legal terms - criminal sanctions against them.. ${ }^{381}$ Legal competence to bear criminal responsibility is reflected in the minimum age of criminal responsibility (MACR), which was presented previously. Discussion about an MACR is equivalent to deliberation about the establishment of an age at which children are presumed legally capable of infringing penal laws. Therefore, it should be noticed and properly highlighted the existence of a direct relationship between being age-competent to infringe criminal law and being agecompetent to be held accountable by criminal law for such infringements. In fact, being capable of violating criminal law, as a consequence, allows one to be held criminally responsible for such a violation (unless the individual has a viable excuse that would exempt his or her criminal responsibility).

\footnotetext{
${ }^{379}$ Cipriani, Children's Rights and the Minimum Age of Criminal Responsibility: A Global Perspective, 3.

${ }^{380}$ Cipriani, Children's Rights and the Minimum Age of Criminal Responsibility: A Global Perspective, 11.

${ }^{381}$ Cipriani, Children's Rights and the Minimum Age of Criminal Responsibility: A Global Perspective, 16.
} 
The right to enlist as a liberty right that entails correlative individual responsibility

Before we engage the question of how liberty rights enable individual responsibility, it is necessary to take a step back and ask an introductory question what rights are and how they relates to responsibility. In Cipriani's words, rights "in the broadest sense, are a special or justified type of claim, or a claim against someone whose recognition as valid is called for by some set of governing rules or moral principles... Such recognition both justifies and distinguishes rights from other types of claims." ${ }^{382}$

Wesley Hohfeld, a Law Professor from the early twentieth century, dedicated his career to building an analytical framework to illuminate how legal relationships between rights and what he called 'their correlatives' played out. He achieved this by deconstructing what legal scholars would attribute to the concept of a 'right,' and analyzing the internal structures and relationships among different fundamental conceptions of legal rights. ${ }^{383}$ Hohfeld identified four different building blocks (or entitlements) composing the idea of legal rights: rights, privileges, powers, and immunities. These four elements had four corresponding correlatives: duty, no right, liability, and disability, respectively. Putting it in practice: "for each entitlement, there is always a unique and distinct correlative disablement and vice versa. Thus, for every right in A, there must be a correlative duty in B. For every privilege in A, there must be a

\footnotetext{
${ }^{382}$ Cipriani, Children's Rights and the Minimum Age of Criminal Responsibility: A Global Perspective, 16.

${ }^{383}$ Singer, Joseph, “Joseph William Singer, The Legal Rights Debate in Analytical Jurisprudence from Bentham to Hohfeld," Wisconsin Law Review, no. 975 (1982), 986-7, http://scholar.harvard.edu/files/jsinger/files/jurisprudence.pdf.
} 
correlative ... (and so on and so forth). The rights and their correlatives form four distinct dyads of legal relations. ${ }^{\$ 34}$

The dyads of "rights-correlatives" "signify that these interests exist on opposing sides of a pair of persons involved in a legal relationship. ${ }^{385}$

For the current work, the goal is not to explain all the elements and their correlative relationships, but rather to focus on the element of "privilege" simply because a privilege functions much like a liberty rights, entitling the holder to exercise the referent act awarded by the right without interference, without being impeded. A privilege is correlated with a no-right, meaning that if someone (A) hold a privilege to do $\mathrm{X}$, then nobody, besides A himself, holds the right to impede A from doing X. We can say, for the purpose of analysis that privilege in Hohfeldian terms is equivalent to our conception of liberty right.

How do MACR and MALR, liberty rights, legal competency and individual criminal responsibility all tie together to answer the question of criminal responsibility of children under International Criminal Law?

A child, after reaching a certain age, is seen by society as legally competent to exercise a particular liberty right, for example, the right to drive. If the child has chosen to enjoy the right in question and is at fault in a lethal car accident, he or she may have breached criminal rules. By being considered legally capable of driving in the first place, the child would be a priori legally capable of and obligated to answer for his or her acts under the criminal justice system.

\footnotetext{
${ }^{384}$ Schlag, Pierre, "How To Do Things With Hohfeld," Law and Contemporary Problems 78, no. 1 (2015): 187, http://scholarship.law.duke.edu/lcp/vol78/iss1/8.

${ }^{385}$ Singer, "The Legal Rights Debate in Analytical Jurisprudence from Bentham to Hohfeld”, 986-87.
} 
Legal competence goes both ways; it enables the liberty right to be exercised (in the presence of choice), and it qualifies the right-holder for individual responsibility if the right in question is exercised in a way that constitutes a crime.

A similar rationale applies to the relationship between the minimum age of legal recruitment (MALR) and the rule/principle of individual criminal responsibility under International Criminal Law. When an individual is deemed mature enough to be granted a liberty right and has chosen to exercise it, the very same legal regime which enables the child to enlist by recognizing them as legally competent - International Humanitarian Law - qualifies them as legally competent to exercise individual responsibility in case of serious breaches of International Humanitarian Law in the course of that exercise. In other words, the criteria for individual responsibility derive from the presumed legal competence that also enables the attribution of a liberty right. Being considered legally capable of being lawfully recruited and serving on the battlefield by International Humanitarian Law also qualifies the individual to be held legally accountable for violations of International Humanitarian Law when performing the acts that this liberty right has enabled him or her to perform. Therefore, legal competence is a two-way street. This argument is essential because it shows that the notions of liberty rights and legal accountability share the same pre-requisite: the presumed legal competence of the individual.

By authorizing juveniles starting at age fifteen to join the military, International Humanitarian Law treats the child who has attained the minimum age of legal recruitment as presumptively legally competent to serve in the military. 
This position is reflected in Articles 77 of Additional Protocol I; part 4 of Additional Protocol II and Article 38 of the CRC.

The goal here is not to challenge the current law by instead arguing that a minor at such an early age is neither psychologically nor emotionally competent to understand what joining the armed forces entails. Rather, as stated before, the goal is simply to highlight the fact that International Humanitarian Law and International Human Rights Law, as currently presented, understand someone as young as fifteen as fully legally capable of exercising the act of joining the armed forces and engaging in armed conflict, and as a consequence, it understands them to be legally competent to respond to any criminal acts they may have committed while on the battlefield.

This chapter of the dissertation has attempted to start a second and complementary line of reasoning for establishing children as legally competent to bear responsibility for their violations of International Humanitarian Law. The new line of reasoning presented in the current chapter stems from the analysis that international law by allowing children starting at age fifteen to legally enlist - grants them liberty rights and thus presumes them legal competent to join the army. I cannot emphasize enough that liberty rights as expressed by Cipriani (2009) presuppose legal competence, which functions as a pre-condition for the attribution of individual criminal responsibility. Having said this, the chapter provided a starting point for a subsequent research project which complements and reinforces the conclusion arrived in the present work: International Law recognizes persons under eighteen as legally capable of joining the military and exercising individual criminal responsibility for serious breaches of international law when certain conditions are met. 


\section{Chapter 9: Conclusion}

\section{Recapitulation of purpose and findings / relationship with previous research}

This dissertation sought to provide a legal analysis on the status of children and children who have committed serious international offenses under International Criminal Law.

I have argued that, in general, when someone is accused of these serious acts, framed as international crimes by international courts, International Criminal Law possesses the capacity to hold the accused directly accountable under the law through domestic and international mechanisms. It is quite clear that all people must abide by International Humanitarian Law and International Human Rights Law, and that serious breaches of these legal regimes give rise to individual criminal responsibility. However, when the accused is someone younger than eighteen, thus considered a child under international legal standards (International Human Rights Law), International Criminal Law has not yet provided a clear position on their status. So the question of whether children bear individual criminal responsibility under international law remains mostly unanswered in nearly all published literature.

Contrary to the general understanding propagated by most published works that there is no established law on the issue of child criminal under international criminal law, the present work can be considered one of the few which shines a different light on the topic, showing how the current law has initiated a legal path towards the viability of holding juveniles accused of international crimes criminally accountable for their acts. The research points to the UN Secretary General's drafting of Article 7.1 of the Statute of 
the Special Court for Sierra Leone which generates evidence of international law on the issue of child criminal responsibility. The decision of the UN Secretary General to include juveniles under the jurisdiction of the Special Court, despite not carrying the weight of mandatory precedent, can be used by other international courts as important guidance as to where the law is in this specific topic. The move to include juveniles, as set forth by the UN Secretary General and approved by the UN Security Council, should be considered revolutionary and adequately acknowledged as an immense step towards achieving a legal position, in International Criminal Law, on child criminal responsibility. Revolutionary for at least two reasons: first, it changes the main legal discourse from framing children exclusively as victims to legally contemplating them as viable perpetrators of international crimes and subjects of the international criminal system.

The present work also suggests a relational link between first, the minimum age of legal recruitment as established by international law, second, the presumed legal competence attributed to minors starting at age fifteen, and finally, the individual criminal responsibility of minors who violate international law in the course of exercising their right to serve and fight.

\section{Limitations of the research (anticipation of criticism)}

A legal positivist analysis, like the one presented, undoubtedly has its limitations. First, we should realize that the topic in question, the criminal accountability of children, is very controversial, and most available inquiries are pervaded with moral interpretations and political criticisms. The current work neither explores the moral and political sides of the problem nor of the legal system's composition; therefore, as an example, it intentionally fails to addresses important questions such as why the legal system is as it is 
and whose interests does it serve? Nor does it investigate whether the existing laws should be interpreted in a way that allows for the element of fairness, justice to be accounted for. Also, it does not raise the question whether the current law is effective and if so, to whom. Another limitation is the lack of analysis related to the language used, precisely if it is embedded with notions of power, or how language is used to perform actions. The analysis also does not delve into questions of legitimacy and how the way law is perceived affects the functioning of legal system. These are a few of the inquiries that, despite being fascinating and of the utmost importance, are left out of the current legal positivist analysis.

Therefore, as mentioned previously, the exclusive interest of a legal positivist analysis (as the one here developed) is to focus on whether there is law on a specific issue, where the law is to be the found, and how the existing source of the law affects its use.

\section{Problems arising from the research}

After scrutinizing the existing research on the question and finding it quite challenging to locate the question of children potential criminal responsibility under international criminal law within existing literature, I noticed that the discussion of potential criminal responsibility of child soldiers in IL and IR literature takes place under a different head; it is in fact framed as inquiry into where a universal MACR should be set. And after reading most of the current works on child soldiers and legal accountability, I concluded that my research question regarding the individual criminal responsibility of children under international criminal law and the discussion of a universal MACR were indeed equivalent inasmuch as they both aimed at constructing a 
space of responsibility for individuals under eighteen at the international level. The primary difference between my research question and the MACR debate was how these two problems were framed. While I framed the inquiry in more legal-theoretical terms, addressing the structure of International Criminal Law, and focusing on the concept of individual criminal responsibility, the discussion on MACR at the international level tend to follow policy concerns and answers to more practical issues.

\section{Implications of my findings/ contributions}

1. This dissertation has found clear evidence of law on the issue of children's criminal responsibility under International Law in the Statue of the SCSL, which can be used by other international courts, thus contributing to the creation and the development of an emerging general rule of International Criminal Law on the issue.

2. This dissertation also suggests that the SCSL by including juveniles starting at age fifteen under the jurisdiction of the court has understood them as viable subjects of the international criminal system, and therefore as presumably legally capable of being criminally responsible for their criminal acts.

3. Overall, this dissertation has extended the field of International Criminal Law by identifying and elucidating the existence of law on the issue of children's criminal responsibility for grave violations of international law.

Recommendations (for research; for action/policy change)

The finding that International Law allows juveniles to answer criminally for serious violations of international law, quite honestly, does not (and should not) come as a surprise if one expects some level of consistency within a legal system. By allowing 
children, starting at age fifteen, to legally enlist and be used in armed conflicts - which in my opinion is preposterous, and can only be understandable if one is looking at recruiting children narrowly in terms of some type military gains, that is, if early enlistment does, in fact, generate military advantage - international law has since pre-determined or strongly influenced its later position on the issue of children's viable criminal treatment for those who have reached the age of legal recruitment. It is logically consistent that someone who is perceived as legally competent to enlist, is also, as the other side of the same coin, to be perceived as legally competent by the same legal system to answer individually for any serious violations they commit while performing the task he or she was authorized to do. Therefore, if one wishes to confront the issue of the presumed legal competence given to minors starting at age fifteen, then states should strongly revise international rules granting these children the right of early enlistment. 


\section{Bibliography}

Akade, Dapo. 2003. "The Jurisdiction of the International Criminal Court over Nationals of Non- Parties: Legal Basis and Limits." Journal of International Criminal Justice 1: 618-50.

http://www.oxfordjournals.org/our journals/jicjus/2003award.pdf.

Akehurst, Michael. 1975. "The Hierarchy of the Sources of International Law." British Yearbook of International Law 47, (1): 273-85. http://bybil.oxfordjournals.org/content/47/1/273.extract.

Alter, Karen J. 2005. "International Courts Are Not Agents! The Perils of the PrincipalAgent Approach to Thinking About the Independence of International Courts." American Society of International Law 99: 138-41. http://www.jstor.org/stable/25659991. Accessed December 04, 2015.

Amann, Diane M. 2005. "The Child Rights Convention and International Criminal Justice." Nordic Journal of International Law 84: 248-69.

https://www.researchgate.net/publication/279239723 The Child Rights Conve ntion and International Criminal Justice.

American Red Cross. 2011. "Prosecution of Violations of IHL." http://www.redcross.org/images/MEDIA CustomProductCatalog/m4640075 IH L ProsecutionofViolations.pdf.

Amnesty International UK. 2000. "Press Release: Sierra Leone: The Statute of the Special Court Must Make All Recruitment of Children under 15 a Crime." October 23. https://www.amnesty.org.uk/press-releases/statute-special-courtmust-make-all-recruitment-childrens-rights-under-15-crime. Accessed February $5,2016$.

Amnesty International. 2000. "Sierra Leone: Recommendations on the Draft Statute of the Special Court." November 14. https://www.essex.ac.uk/armedcon/story id/000143.html.

Ang, Fiona. 2005. A Commentary on the United Nations Convention on the Rights of the Child: Article 38: Children in Armed Conflicts. Leiden: Martinus Nijhoff Publishers. .2006. Participation Rights of Children. Antwerpen: Intersentia, 2006.

Aptel, Cecile. 2010. "Children and Accountability for International Crimes: The Contributions of the International Criminal Courts." In Innocenti Working Paper 2010-20. 
Archard, David. 2004. Children, rights and childhood. 2nd ed. London: Routledge. . 2011. "Children's Rights." Stanford Encyclopedia of Philosophy. http://plato.stanford.edu/entries/rights-children/.

Archard, David, and Colin M. Macleod. 2002. The moral and political status of children. Oxford Scholarship Online.

Asquith, Steward. 1996. "When Children Kill Children: The Search for Justice." Sage Journals 3: 99-116. http://chd.sagepub.com/content/3/1/99.abstract.

Austin, John. 1832. The Province of Jurisprudence Determined. London: John Murray,

Avalon Project. http://avalon.law.yale.edu/. Accessed March 11, 2016.

Baimu, Evarist. 2009. “International Protection of Children.” In Max Plank Encyclopedia of Public International Law, Oxford Public International Law. http://opil.ouplaw.com/view/10.1093/law:epil/9780199231690/law9780199231690-e904?rskey=kNAAma\&result=1\&prd=EPIL.

Baron, Marcia. 2005. "Justification and Excuses." Ohio State Journal of Criminal Law 2: 387-406. Accessed: 3 May, 2017.

Bayles, Michael D. 1982. "Character, Purpose and Criminal Responsibility." Law and Philosophy 1, (1): 5-20. Accessed January 01, 2016.

BBC News. 2007. “Under-18's Were Deployed to Iraq.” News Media. BBC News. Feb.04.http://news.bbc.co.uk/2/hi/uk/6328771.stm. . 2015."Anzac Day Terror Plot: Blackburn Boy Sentenced to Life.” BBC, October 2, 2015. http://www.bbc.com/news/uk-34423984. Accessed August 3, 2015.

Bennion, Francis. 2009. "Mens rea and defendants below the age of discretion." Criminal Law Review: 757-70. http://www.francisbennion.com/pdfs/fb/2009/2009-031crim-lr-doli-in-capax.pdf. Accessed Apr. 25, 2017.

Boeck, Filip, and Alcinda Honwana, eds. 2005. Makers \& Breakers: Children \& Youth in Postcolonial Africa. Africa World Press.

Borda, Aldo. 2013. "Precedent in International Criminal Courts and Tribunals." Cambridge Journal of International and Comparative Law 2 (2): 287-313. http://joomla.cjicl.org.uk/journal/article/112. 
Boven, Theo Van. 2010. "The United Nations Basic Principles and Guidelines on the Right to a Remedy and Reparation for the Victims of Gross Violations of International Human Rights Law and Serious Violations of International Humanitarian Law." United Nations Audiovisual Library of International Law. http://legal.un.org/avl/pdf/ha/ga 60-147/ga 60-147 e.pdf.

Breen, Claire. 2006."From Paternalism to (Partial) Autonomy: The Evolution of Children's Rights in New Zealand.” New Zealand Journal of History 40: 91-101.

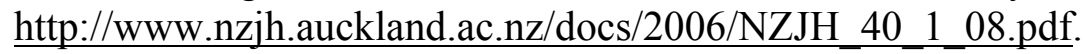

Brett, Rachel, and Margareth McCallin. 1998. Children: The Invisible Soldiers. Edited by Radda Barnen. Vol. 2. Stockholm: Save the Children.

Briggs, Herbert. 1952. "New Dimension in International Law." The American Political Science Review 46, (3): 667-98. www.jstor.org/stable/1952278. Accessed December 13, 2013.

Brons, Kathryn. 2013. Assessing the Innocence and Victimization of Child Soldiers. Master diss., University of Alabama, Tuscaloosa, AL: 1-59. http://acumen.lib.ua.edu/content/u0015/0000001/0001380/u00150000001 0001 380.pdf

Bueren, Geraldine Van, and André Alen. 2006. A Commentary on the United Nations Convention on the Rights of the Child. Leiden: Nijhoff.

Cassel, Douglass. 2001."Empowering United States Courts to Hear Crimes Within the Jurisdiction of the International Criminal Court"" New England Law Review 35, no. 421. http://www.nesl.edu/userfiles/file/lawreview/vol35/2/cassel.pdf.

Cassese, Antonio. 2003. "International Criminal Law.” In International Law, edited by Evans Malcolm. 1st ed. . 2005. International Law. Oxford: Oxford University Press. . 2008. International Criminal Law. Oxford: Oxford University Press. . 2009. "Aut Dedere Aut Judicare." In The Oxford Companion to International.

Charlesworth, Hillary. 2002. "International Law: A Discipline of Crisis." The Modern Law Review 65, no. 3: 377-92. www.jstor.org/stable/1097579.

Child Rights International Network. "Minimum Ages of Criminal Responsibility in the Americas" https://www.crin.org/en/home/ages/Americas. Accessed May 20, 2017.

Child Soldiers International. 2012. "Louder Than Words: An Agenda to End State Use of Child Soldiers.” http://child-soldiers.org/global report reader.php?id=562. Accessed February 03, 2016. 
CIA. World FactBook. "Military Service Age and Obligations." https://www.cia.gov/library/publications/the-world-factbook/fields/2024.html.

Cipriani, Don. 2009. Children's Rights and the Minimum Age of Criminal Responsibility: A Global Perspective. Farnham, Surrey, England: Ashgate Pub. . 2013. "The minimum age of criminal responsibility." Penal Reform International/ UKaid. N.p., Accessed 6 Apr. 2017.

Clapham, Andrew. 2003. "Issues of Complexity, Complicity and Complementary: from the Nuremberg trials to the dawn of the new International Criminal Court." From Nuremberg to The Hague: The Future of International Criminal Justice, edited by Sands, Phillipe. Cambridge: Cambridge University Press: 31.

Claude, Inis L. 1996. "Collective Legitimization as a Political Function of the United Nations," In International Organization 20 (03): 367-79. doi: https://doi.org/10.1017/S0020818300012832. Accessed April 12, 2017.

Coalition to Stop the Use of Child Soldiers. 2008. "Child Soldiers Global Report 2008Summary." http://www.child-soldiers.org/global report reader.php?id=97. Court for Amnesties and Truth Commissions." Edited by A. Von Bogdandy and R. Wolfrum. Max Planck Yearbook of United Nations Law 7 (2003): 553-90. http://www.mpil.de/files/pdf3/mpunyb seibert-fohr 7.pdf.

Crane, David. 2008. "Prosecuting Children in Times of Conflict: The West African Experience." Human Rights Brief 15, (3): 11-17. http://digitalcommons.wcl.american.edu/cgi/viewcontent.cgi?article=1029\&cont ext=hrbrief.

Crawford, James R. 2006. "State Responsibility." Max Planck Encyclopedia of Public International Law. http://opil.ouplaw.com/view/10.1093/law:epil/9780199231690/law9780199231690-e1093?rskey=Av0dbV\&result=1\&prd=EPIL.

Crawford, James, and Simon Olleson. 2010. "The Nature and Forms of International Responsibility." In International Law, edited by Malcolm Evans, 3rd ed. Oxford and New York: Oxford University Press: 441-71.

Cryer, Robert, Håkan Friman, Darryl Robinson, and Elizabeth Wilmshurst. 2007. An Introduction to International Criminal Law and Procedure. 1st ed. Cambridge: Cambridge University Press.

Cryer, Robert. 2005. Prosecuting International Crimes: Selectivity and the International Criminal Law Regime. Cambridge: Cambridge University Press. 
Detrick, Sharon, J. E. Doek, and Nigel Cantwell. 1992. The United Nations Convention on the Rights of the Child: A Guide to the "Travaux Préparatoires" Dordrecht: M. Nijhoff Publishers.

Detrick, Sharon. 1999. A commentary on the United Nations Convention on the Rights of the Child. The Hague: M. Nijhoff Publishers.

Drumbl, Mark. 2012. Reimagining Child Soldiers in International Law and Policy. Oxford: Oxford University Press. . 2015. "The Ongwen Trial at the ICC: Tough Questions on Child Soldiers." Open Democracy. https://www.opendemocracy.net/openglobalrights/markdrumbl/ongwen-trial-at-icc-tough-questions-on-child-soldiers. Accessed January 20, 2016.

Drury, Ian. 2015. "UK Sent 'children' to Iraq and Afghanistan despite Government Ban." Daily Mail. http://www.dailymail.co.uk/news/article-2050684/UK-sent-childrenIraq-Afghanistan-despite-Government-ban.html.

Duff, Anthony. 2003. "I Might Be Guilty, But You Can't Try Me": Estoppel and Other Bars to Trial." Ohio State Journal of Criminal Law: 245-59. http://moritzlaw.osu.edu/osjcl/Articles/Volume1 1/Commentary/duff.pdf. . 2009. "Legal and Moral Responsibility." Philosophy Compass 4.6: 978-86. Wiley Online Library. .2013. "Theories of Criminal Law." The Stanford Encyclopedia of Philosophy. http://plato.stanford.edu/entries/criminal-law/.

Earls, Felton. 2011. "Children: From Rights to Citizenship." American Academy of Political and Social Science 633: 6-16. www.jstor.org/stable/27895957. Accessed September 5, 2015.

Feinberg, Joel. 1970. "The Nature and Value of Rights." The Journal of Value Inquiry 4: 243-57.

Feldman, Allen. 2002. "X-Children and the Militarization of Everyday Life: Comparative Comments on the Politics of Youth, Victimize and Violence in Transitional Societies." International Journal of Social Welfare 11, (4): 286-99. http://onlinelibrary.wiley.com/doi/10.1111/1468-2397.00238/abstract.

Fellmeth, Aaron, and Maurice Horwitz. 2011. Guide to Latin in International Law. Oxford University Press.

Felton, John. 2008. "Child Soldiers." CQ Researcher Press Library. http://library.cqpress.com/cqresearcher/document.php?id=cqrglobal2008070000. Accessed September 2015. 
Finnin, Sarah. 2012. "Mental Elements Under Article 30 of the Rome Statute of the International Criminal Court: A Comparative Analysis." International and Comparative Law Quarterly 61 (2): 325-59.

Finnis, John. 2011. "The Truth in Legal Positivism.” In The Autonomy of Law, edited by Robert P. George, 195-214. Oxford: Clarendon Press. doi:10.1093/acprof:oso/9780199580088.003.0008

Fionda, Julia, ed. 2001. Legal Concepts of Childhood. Hart Publishing.

Fottrell, Deirdre. 2000. Revisiting Children's Rights: 10 Years of the UN Convention on the Rights of the Child. The Hague: Kluwer Law International.

Freeland, Joseph. 2010. "How International Law Deals with Child Soldiers." ALTA Law Research Series. http://www.austlii.edu.au/au/journals/ALRS/2010/10.html.

Freeland, Steven. 2005. "Child Soldiers and International Crimes: How Should International Law Applied?" New Zealand Journal of Public and International Law 3 (2): 303-28. http://www.victoria.ac.nz/law/centres/nzcpl/publications/nzjournal-of-public-and-international-law/previous-issues/volume-32,-november2005/freeland.pdf.

Frulli, M. 2000. "The Special Court for Sierra Leone: Some Preliminary Comments." European Journal of International Law 11 (4): 857-69. Accessed October 10, 2015.

Gardner, John. 2003. "The Mark of Responsibility." Oxford Journal of Legal Studies 23:157-71.

Gberie, Lansana. 2014. "The Special Court for Sierra Leone rests - for good.” Africa Renewal Online. http://www.un.org/africarenewal/magazine/april-2014/specialcourt-sierra-leone-rests--good. Accessed March 24, 2017.

Glanville, Luke. 2010. "The Antecedents of 'Sovereignty as Responsibility."” European Journal of International Relations. http://ejt.sagepub.com/content/17/2/233. short?rss=1\&ssource=mfr.

Gorski, Simone. 2013. "Individuals in International Law.” Max Planck Encyclopedia of Public International Law. http://opil.ouplaw.com/view/10.1093/law:epil/9780199231690/law9780199231690-e829?rskey=dC9WxL\&result=1\&prd=EPIL. 
Graditzky, Thomas. 1998. "Individual Criminal Responsibility for Violations of International Humanitarian Law Committed in Non-International Armed Conflicts." International Review of the Red Cross. https://www.icrc.org/eng/resources/documents/misc/57jp4l.htm.

Green, Leslie. 2009. "Legal Positivism.” The Stanford Encyclopedia of Philosophy. 2009. https://plato.stanford.edu/archives/fall2009/entries/legal-positivism/>. Accessed March 24, 2017.

Greenwood, Christopher. 2008. "Sources of International Law: An Introduction." UN Office of Legal Affairs. http://legal.un.org/avl/pdf/ls/Greenwood outline.pdf.

Greppi, Edoardo.1999. "The Evolution of individual criminality under international law." International Review of the Red Cross 835. https: $/ /$ www.google.com $/$ url? sa $=\mathrm{t} \& \mathrm{rct}=\mathrm{j} \& \mathrm{q}=\& \mathrm{esrc}=\mathrm{s} \&$ source $=\mathrm{web} \& \mathrm{~cd}=1 \& \mathrm{ved}=$ 0ahUKEwih643nru3SAhVU22MKHZwzCNsQFggaMAA\&url=http\%3A\%2F\% 2Fwww.umass.edu\%2Flegal\%2FBenavides\%2FFall2004\%2F397G\%2FElectroni c\%2520Reserve\%2F12\%2520Greppi.doc\&usg=AFQjCNHeEDIHO6B18MyAw yxK7D-dwF1o5w\&bvm=bv.150475504,d.amc

Grover, Sonja. 2012. Child Soldier Victims of Genocidal Forcible Transfer Exonerating Child Soldiers Charged with Grave Conflict-related International Crimes. Berlin: Springer.

Happold, Matthew. 2000. "Child Soldiers in International Law: The Legal Regulations of Children's Participation in Hostilities." Netherlands International Law Review 1 (XLVII): 27-52. http://sro.sussex.ac.uk/id/eprint/26771. .2006. "The Age of Criminal Responsibility for International Crimes Under International Law." In From Peace to Justice Series International Criminal Accountability and Rights of Children, edited by Karin Arts and Vesselin Popovski: 69-84. Hague Academic Press. . 2008. “Child Soldiers: Victims or Perpetrator?" University of La Verne Law Review:56-87. HeinOline.

Haque, Adil. 2008."Answering For Crime: Responsibility and Liability In Criminal Law, by R.A. Duff." Review of Answering For Crime: Responsibility and Liability In Criminal Law, by R.A. Duff. Rutgers School of Law Newark, May 2008. Accessed February 8, 2016.

Hart, H. L. A. 1969. Punishment and Responsibility: Essays in the Philosophy of Law. New York: Oxford University Press.

Hart, Jason. 2006. "Saving Children: What Role for Anthropology?" Anthropology Today 22, (1):1-8. http://anthro.vancouver.wsu.edu/media/Course files/anth-302-barryhewlett/hart-saving-children.pdf. Accessed January 05, 2016. 
Hartmann, Michael E. 2003. "International Judges and Prosecutors in Kosovo: A New Model for Post-Conflict Peacekeeping." United States Institute of Peace. http://www.usip.org/publications/international-judges-and-prosecutors-inkosovo-new-model-post-conflict-peacekeeping.

Helle, Daniel. 2000. "Optional Protocol on the Involvement of Children in Armed Conflict to the Convention on the Rights of the Child." International Committee of the Red Cross. https://www.icrc.org/eng/resources/documents/misc/57jqqe.htm. Accessed February 03, 2016.

Hencaerts, Jean-Marie. 2005. "Study on Customary International Humanitarian Law: A Contribution to the Understanding and Respect for the Rule of Law in Armed Conflict." International Review of the Red Cross 07 (857):175-259. https://www.icrc.org/eng/resources/documents/article/review/review-857p175.htm. Accessed February 2015.

Heppner, Kevin. 2002. “My Gun Was as Tall as Me”: Child Soldiers in Burma. New York, NY: Human Rights Watch.

Higgins, Rosalyn. 1994. Problems and Process: International Law and How We Use it. Oxford: Oxford University Press.

Hirby, J. "What You Can Legally Do When You're 18.” The Black's Law Dictionary. http://thelawdictionary.org/article/what-you-can-legally-do-when-youre-18/.

Hohfeld, Wesley N. 1917. "Fundamental Legal Conceptions as Applied in Judicial Reasoning." Faculty Scholarship Series. Paper 4378: 710-70. http://digitalcommons.law.yale.edu/cgi/viewcontent.cgi? article $=5383 \&$ context $=\mathrm{f}$ ss papers.

Honwana, Alcinda. 2005. "Innocent and Guilty: Child-Soldiers as Interstitial and Tactical Agents.” In Makers \& Breakers: Children \& Youth in Postcolonial Africa, edited by Alcinda Honwana and Filip Boeck: 31-52. Africa World Press.

Hoover, Joseph. 2014. "Moral Practices: Assigning Responsibility in the International Criminal Courts." Law and Contemporary Problems 76: 263-86. http://scholarship.law.duke.edu/lcp/vol76/iss3/8.

Horder, Jeremy. 1996. "Determinism, Liberalism, and Criminal Law." Current Legal Problems, 49. https://www.princeton.edu/jpia/past-issues-1/2001/8.pdf.

Hulme, Karen. "Child Soldiers in International Law- Review." The Modern Law Review Limited 71 (2008): 496-99. http://onlinelibrary.wiley.com/doi/10.1111/j.1468$\underline{2230.2008 .00703 \quad 2 . x / \text { abstract. }}$ 
Humanium. "Together for Children's Rights." https://www.humanium.org/en/. Accessed February 04, 2016.

ICRC. 1949. "Geneva Convention (IV) Relative to the Protection of Civilian Persons in Time of War. Geneva, 12 August 1949." https://www.icrc.org/ihl/INTRO/380 . 1977. "Protocol Additional to the Geneva Conventions of 12 August 1949, and Relating to the Protection of Victims of International Armed Conflicts (Protocol I), 8 June 1977." https://www.icrc.org/ihl.nsf/INTRO/470. . 1977. "Protocol Additional to the Geneva Conventions of 12 August 1949, and Relating to the Protection of Victims of Non-International Armed Conflicts (Protocol II).” https://www.icrc.org/ihl.nsf/INTRO/475?OpenDocument. . 2005. "Rule 135: Children Affected by Armed Conflict Are Entitled to Special Respect and Protection." https://www.icrc.org/customaryihl/eng/docs/v1 rul rule135. . 2010. "Children Protected Under International Humanitarian Law: Overview." https://www.icrc.org/eng/war-and-law/protected-persons/children/overviewprotected-children.htm. . 2010. ICRC. Rule 151: Persons Protected under IHL. https://www.icrc.org/eng/war-and-law/protected-persons/overview-protectedpersons.htm. Accessed February 03, 2016 . 2014. "Geneva Conventions." https://www.icrc.org/en/war-and-law/treatiescustomary-law/geneva-conventions. Accessed February 04, 2016.

International Council on Human Rights. 1999. "Taking Duties Seriously: Individual Duties in International Human Rights Law: A Commentary." http://www.ichrp.org/files/reports/10/103 report en.pdf.

International Criminal Court. "Rome Statute of the International Criminal Court." https://www.icc-cpi.int/nr/rdonlyres/ea9aeff7-5752-4f84-be940a655eb30e16/0/rome statute english.pdf.

International Labour Organizations. 2015."Child Labour and Armed Conflict.” http://www.ilo.org/ipec/areas/Armedconflict/lang--en/. Accessed November 2015.

Internet Encyclopedia of Philosophy. "Human Rights.". http://www.iep.utm.edu/humrts/. Accessed March 2015.

Jalloh, Charles. 2007. Consolidated Legal Texts for the Special Court for Sierra Leone. Leiden, The Netherlands: Martinus Nijhoff Publishers. .2011. "Special Court for Sierra Leone: Achieving Justice?" Michigan Journal of International Law: 395-460. http://search.proquest.com.jproxy.lib.ecu.edu/docview/867094271/fulltext/55519 2246F434153PQ/8? accountid=10639. Accessed January 22, 2016. 
. 2015. "The Contribution of the Special Court for Sierra Leone to the Development of International Law." RADIC, 2007, 165-207. Accessed November 10, 2015.

Kaczorowska, Alina. Public International Law. Abingdon, Oxon: Routledge, 2010.

Kassier, Glenn. "The zombie claim that 300,000 children are used as child soldiers." The Washington Post, January 22, 2016. https://www.washingtonpost.com/news/factchecker/wp/2016/01/22/the-zombie-claim-that-300000-children-are-used-aschild-soldiers/. Accessed March 24, 2017.

Kittichaisaree, Kiangsak. International Criminal Law. Oxford: Oxford University Press, 2001.

Kress, Claus. "International Criminal Law.” Max Planck Encyclopedia of Public International Law. March 2009. http://opil.ouplaw.com/view/10.1093/law:epil/9780199231690/law9780199231690-e1423?rskey=OAHNkL\&result=7\&prd=EPIL.

Lazarev, Nikolai. 2005. "Hohfeld's Analysis of Rights: An Essential Approach to a Conceptual and Practical Understanding of the Nature of Rights." Murdoch University Electronic Journal of Law 9. http://www.austlii.edu.au/au/journals/MurUEJL/2005/9.html.

Legal Information Institute Cornell University Law School. 2007. "In Rights of the Child: Proceedings of the International Conference, Ottawa 2007 Infancy." https://www.law.cornell.edu/wex/infancy. Accessed February 5, 2016.

Leiter, Brian. 2010. "Why Legal Positivism?” Draft of December 10, 2009 for presentation at the AALS panel on "Legal Positivism: For and Against" with Leslie Green, Mark Greenberg, \& Jeremy Waldron, New Orleans, January 9, 2010.

Lenk, Hans. 2015. "What Is Responsibility?” Philosophy Now.

Leveau, Fanny. 2013. "Liability of Child Soldiers Under International Criminal Law." Osgoode Hall Review of Law and Policy 4, no. 1: 36-66.

http://digitalcommons.osgoode.yorku.ca/cgi/viewcontent.cgi?article=1006\&cont ext=ohrlp.

Lineberry, Cate. 2011. "The Boys of War." The New York Times, October 4. http://opinionator.blogs.nytimes.com/2011/10/04/the-boys-of-war/? $\mathrm{r}=0$. 
Mackenzie, Ruth, and Philippe Sands. 2003. "International Courts and Tribunals and the Independence of the International Judge." 44: 271-85. http://www.pictpcti.org/publications/PICT articles/mackenzie2.pdf. Accessed February 3, 2016.

Maclean, Sally. 2006. "Child Cruelty or Reasonable Punishment? A Case Study of the Operation of the Law and the Courts 1883-1903." New Zealand Journal of History 40, no. 1: 7-24.

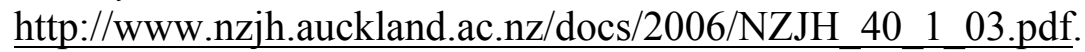

Maher, Gerry. 2005. “Age and Criminal Responsibility.” Ohio State Journal of Criminal Law, 493rd ser., 2: 493-512. http://moritzlaw.osu.edu/students/groups/osjcl/files/2012/05/Maher-PDF-4-11$\underline{05 . p d f}$.

Mann, Howard. 1987. "International Law and the Child Soldier." The International and Comparative Law Quarterly 36, no. 1 (January): 32-57. www.jstor/org/stable/760458.

Marten, James Alan., ed. 2002. Children and War: A Historical Anthology. New York: New York University Press.

Mbembe Binda, Me Elvis. "Decreasing the Age of Criminal Majority in Rwanda, an Issue to Rethink About." Reflexions Juridiques et Socio-Politiques Sur La Region des Grands Lacs Africains http://bindael.weebly.com/criminal-majorityin-rwanda.html.

McCorquodale, Robert. 2010. "The Individual and the International Legal System." In International Law, edited by Malcolm Shaw, 284-310. 3rd ed. Oxford and New York : Oxford University Press, 2010.

Mettraux, Guénaël. 2011. "Trial at Nuremberg." In Routledge Handbook of International Criminal Law, edited by William Schabas and Nadia Bernaz. New York: Routledge: 5-16.

Morales, Alba. 2014. "Dispatches: US Should Stop Prosecuting Kids as Adults." Human Rights Watch. March 11. https://www.hrw.org/news/2014/03/11/dispatches-usshould-stop-prosecuting-kids-adults.

Nmehielle, Vincent O., and Charles C. Jalloh. 2006. "The Legacy of The Special Court for Sierra Leone." Fletcher Forum of World Affairs 30: 107124.http://heinonline.org.jproxy.lib.ecu.edu/HOL/Print?collection=journals\&han $\underline{\mathrm{dle}}=$ hein.journals/forwa30\&id=357. Accessed January 22, 2016 
No Peace Without Justice and UNICEF Innocenti Research Centre. 2002. "International Criminal Justice and Children.” Accessed February 2015. http://www.unicef.org/emerg/files/ICJC.pdf.

Nollkaemper, Andre, and Jann Kleffner. 2004. Internationalized Criminal Courts: Sierra Leone, East Timor, Kosovo and Cambodia. Edited by Cesare Romano. Oxford: Oxford University Press.

Northwestern Law: Pritzker Legal Research Center. "Sources of International Law." http://www.law.northwestern.edu/library/research/international/gettingstarted/so urcesofintllaw/. Accessed February 18, 2016.

Nouwen, Sarah. 2006. “'Hybrid Courts': The Hybrid Category of a New Type of International Crimes Courts." Utrecht Law Review 2, 2 (December 5). https://www.utrechtlawreview.org/articles/abstract/10.18352/ulr.32/.

Nybondas, Maria. 2004. "The Relationship Between Individual Criminal and Command Responsibility." Journal of International Criminal Justice.

Office of the Special Representative of the Secretary-General for Children and Armed Conflict. 2011. "Children and Justice During and in the Aftermath of Armed Conflict." https://childrenandarmedconflict.un.org/publications/WorkingPaper3 Children-and-Justice.pdf.

Office of the United Nations High Commissioner for Human Rights. 2007. "UN Committee on the Rights of the Child, General Comment $\mathrm{N}^{\circ} 10$..." http://www2.ohchr.org/english/bodies/crc/docs/CRC.C.GC.10.pdf. Accessed February 04, 2016.

Oxford Reference. "Gillick Competence." http://www.oxfordreference.com/view/10.1093/oi/authority.2011080309585266. Accessed February 05, 2016.

Palmisano, Giuseppe. 2001. "Fault.” Max Planck Encyclopedia of Public International Law. Paper presented at a conference on Judicial Independence at the Crossroads: Developing an Interdisciplinary Research Agenda, held at the University of Pennsylvania School of Law, Mar. 31-Apr. 1. http://opil.ouplaw.com/view/10.1093/law:epil/9780199231690/law9780199231690-e1955?rskey=WE0mrG\&result=8\&prd=EPIL.

Paust, Jordan P., M. Bassiouni, Jimmy Gurule, Leila Sadat, and Bruce Vagaries. 2006. International Criminal Law: Cases and Material. 3rd ed. Carolina Academic Press. 
Pittman, Thomas, and Matthew Heaphy. 2008. "Does the United States Really Prosecutes Its Service Members for War Crimes? Implications for Complementarity before the International Criminal Court." Leiden Journal of International Law 21: 165183. http://www.amicc.org/docs/LJIL 2008 21-1_Pittman_Heaphy.pdf.

Pocar, Fausto. 2002. "To What Extent Is Protocol I Customary International Law?" International Law Studies 78. https://www.usnwc.edu/getattachment/71 feb041f08d-4e4a-ac23-7c161c4d26ab/30--To-What-Extent-Is-Protocol-I-CustomaryInterna.aspx.

Poulatova, Chaditsa. 2013. Children and Armed Conflict. Newcastle, UK: Cambridge Scholars.

Provost, René. 2016. "Targeting Child Soldiers." Web log post. EJIL:Talk! Blog of the European Journal of International Law, 12 Jan. Web. 6 Apr. 2017.

Rangoolie, Monique. 2001. "Prosecution of Sierra Leone's Child Soldier: What Message Is the UN Trying to Send?” Journal of Public and International Affairs 12:145-61.

Reilly, Anne. 2017. "Affirmative Defenses in International Criminal Proceedings." In Defense Perspectives on International Criminal Justice?, edited by Collen Rohan and Gentian Zyberi. New York, NY: Cambridge University Press.

Rikhof, Joseph. 2008. Child Soldiers: Should They Be Punished? Montréal, QC: Wilson \& Lafleur (W\&L).

Rivard, Lysanne. 2010. "Child Soldiers and Disarmament, Demobilization and Reintegration Programs: The Universalism of Children's Rights vs. Cultural Relativism Debate." The Journal of Humanitarian Assistance, August 23. https://sites.tufts.edu/jha/archives/772. Accessed March 25, 2017

Rivet, Annabelle Karen. 2014. The Criminal Liability of Child Soldiers in International Criminal Law: Does Restorative Justice Offer a Balance Between the Rights of the Victim and the Right of the Child Perpetrator? LLM diss., University of Pretoria.

Romero, Joshua A. 2004. "The Special Court for Sierra Leone and the Juvenile Soldier Dilemma." Northwestern Journal of International Human Rights 2, no. 1. http://scholarlycommons.law.northwestern.edu/cgi/viewcontent.cgi?article=1011 \&context=njihr.

Rosen, David M. 2005. Armies of the Young: Child Soldiers in War and Terrorism. New Brunswick, NJ: Rutgers University Press. 
Rosen, David M. 2012. Child Soldiers: A Reference Handbook. Santa Barbara, CA: ABC-CLIO.

Sadat, Leila. 2011. "Understanding the complexities of international criminal tribunal jurisdiction." In Routledge Handbook of International Criminal Law, edited by William Schabas and Nadia Bernaz, 197-210. New York: Routledge.

Scarman, Gillick. "The Age of Criminal Responsibility.” Law Teacher.net. http://www.lawteacher.net/free-law-essays/criminal-law/age-of-criminalresponsibility.php.

Schaack, Beth Van, and Ronald C. Slye. 2014. International Criminal Law and its enforcement: cases and materials. 3rd ed. MN: Foundation Press.

Schabas, William, and Nadia Bernaz. 2011. Routledge Handbook of International Criminal Law. Abingdon, Oxon: Routledge.

Schabas, William. 2006. The UN International Criminal Tribunals: The Former Yugoslavia, Rwanda, and Sierra Leone. Cambridge, UK: Cambridge University Press, 2006. . 2007. "Defences." An Introduction to International Criminal Court, 226-320. 3rd ed. Cambridge University Press. .2010. The International Criminal Court: A Commentary on the Rome Statute. Oxford: Oxford University Press, 2007 and 2010.

Scharf, Michael and Margaux Day. 2011."The ad hoc international criminal tribunals: launching a new era of accountability." In Routledge Handbook of International Criminal Law, edited by William Schabas and Nadia Bernaz, 51-66. New York: Routledge.

Schlag, Pierre. 2015. "How to do Things With Hohfeld." Law and Contemporary Problems 78, no. 1: 185-234. http://scholarship.law.duke.edu/lcp/vol78/iss1/8.

Seibert-Fohr, Anja. 2003. "The Relevance of the Rome Statute of the International Criminal Court for Amnesties and Truth Commissions." Edited by A. Von Bogdandy and R. Wolfrum. Max Planck Yearbook of United Nations Law 7: 55390. http://www.mpil.de/files/pdf3/mpunyb seibert-fohr 7.pdf.

Shelton, Dinah. 2009. "Form, Function, and the Power of International Courts." Chicago Journal of International Law 9, no. 2: 537-71. Accessed November 10, 2015. http://search.proquest.com.jproxy.lib.ecu.edu/docview/237210811?pqorigsite $=$ summon.

Simma, Bruno, and Andreas L. Paulus. "The Responsibility of Individuals for Human Rights Abuses in Internal Conflicts." The American Journal of International 
Law, April 1999, 302-16. http://www.jstor.org/stable/2997991. Accessed January 18, 2016.

Singer, Joseph. 1982. "The Legal Rights Debate in Analytical Jurisprudence from Bentham to Hohfeld." Wisconsin Law Review, no. 975: 980-1059. http://scholar.harvard.edu/files/jsinger/files/jurisprudence.pdf.

Singer, Peter W. 2005. "Child Soldiers: The New Faces of War." Brookings Institution. http://www.brookings.edu/ /media/research/files/articles/2005/1/winter islamicworld singer/singer20051215. . Children at War. Berkeley: University of California Press, 2006.

Somasundaram, Days. 2002. "Child Soldiers: Understanding the Context." Bmj 324 (7348): 1268-271.

State Side Legal. 2010. "Emancipation and Military Service." http://statesidelegal.org/emancipation-and-military-service.

Steel, Michelle. 2008. "Child Soldiers." Vision. http://www.vision.org/visionmedia/social-issues/child-soldiers/6684.aspx. Accessed December 1, 2014.

Tadros, Victor. 2005.Criminal Responsibility. Oxford: Oxford University Press.

Tedeschi, Doug, and Erin Rodgers. 2005. "Tackling A Brave New World: A Guide to the Basics of International Law.” The Writing Center - Georgetown University Law Center. http://legal.un.org/avl/pdf/ha/ga 60-147/ga 60-147 e.pdf.

Terris, Daniel, Cesare P. R. Romano, and Leigh Swigart. 2007. The international judge: an introduction to the men and women who decide the world's cases. Oxford: Oxford University Press.

The American Non Governmental Organizations Coalition for the International Criminal Court. "The International Criminal Court and Children's Rights." http://www.amicc.org/docs/childrenFAQs.pdf.

The Guardian. 2000. "Two little boys.” News Media. The Guardian July 27. https://www.theguardian.com/g2/story/0,3604,347432,00.html

The International Center for Transitional Justice. "Criminal Justice." https://www.ictj.org/our-work/transitional-justice-issues/criminal-justice. Accessed February 01, 2017 
The International Law Commission, Second Session Source. 1950. "The Trial of the Major War Criminals before the International Military Tribunal"." International Organization 4 (4): 714-21. Accessed May 1, 2017.

The Letric Law Library. “The Infancy Defense.” http://www.lectlaw.com/mj1/cl032.htm. Accessed February 5, 2016.

The Redress Trust. 2006. "Victims, Perpetrators or Heroes? Child Soldiers before the International Criminal Court." http://www.redress.org/downloads/publications/childsoldiers.pdf. Accessed May 2017.

The Robert H. Jackson Center. "The Influence of the Nuremberg Trial on International Criminal Law.” Edited by Tove Rosen: https://www.roberthjackson.org/speechand-writing/the-influence-of-the-nuremberg-trial-on-international-criminal-law/.

The Special Court for Sierra Leone, the Residual Special Court for Sierra Leone. "The Statute of the Special Court for Sierra Leone." http://www.rscsl.org/Documents/scsl-statute.pdf.

Trakman, Leon, and Sean Gatien. 1999. Rights and Responsibilities. University of Toronto Press.

Trial International. “Universal Jurisdiction.” http://www.trialch.org/en/resources/international-law/universal-jurisdiction.html.

UK Aid and Penal Reform International. 2013. "The Minimum Age of Criminal Responsibility.” Justice for Children Briefing. February 2013. http://www.penalreform.org/wp-content/uploads/2013/05/justice-for-childrenbriefing-4-v6-web 0.pdf.

UN Audiovisual Library of International Law. "Convention on the Rights of the Child and Optional Protocols Thereto.” Accessed March 01, 2015.

UN Docs. "Geneva Declaration of the Rights of the Child of 1924." http://www.undocuments.net/gdrc1924.htm. Accessed February 04, 2016.

UNAMSIL. "Documents on the Establishment of the Special Court for Sierra Leone.”http://www.un.org/en/peacekeeping/missions/past/unamsil/spcourt.htm.

UNGA. 2005. "Report of the Special Representative of the Secretary-General for Children and Armed Conflict to the General Assembly." UN General Assembly Official Document. September 7. http://www.unicef.org/emergencies/files/report SRSG cac.pdf. . 2008. "Report of the Committee on the Rights of the Child." General Assembly 
Official Records Sixty-third Session Supplement No. 41. 2008. https://www.iom.int/jahia/webdav/shared/shared/mainsite/policy and research/u n/63/A 63 41.pdf.

. 2014. "Secretary-General's Annual Report on Children and Armed Conflict Documents Continued Child Suffering in 23 Conflict Situations." May, 14. http://www.un.org/ga/search/view doc.asp?symbol=a/68/878. . 2014."Children and Armed Conflict: Annual Report of the Secretary General." http://www.un.org/ga/search/view doc.asp?symbol=a/68/878.

UNICEF and UN Special Representative of the Secretary General for Children and Armed Conflict. 2003. "Children and Armed Conflict: International Standards for Action.” http://www.unicef.org/emerg/files/HSNBook.pdf.

UNICEF. 1996.“Report of Graca Machel: Impact of Armed Conflict on Children.” 1996. http://www.unicef.org/graca/a51-306 en.pdf.

. 1997. "Cape Town Principles and Best Practices on the Recruitment of Children into the Armed Forces and on Demobilization and Social Reintegration of Child Soldiers in Africa." http://www.unicef.org/emergencies/files/Cape Town Principles(1).pdf. . 1998. "Juvenile Justice." UNICEF Innocenti Digest. http://www.unicefirc.org/publications/pdf/digest3e.pdf.

. 2003. "Guide to the Optional Protocol on the Involvement of Children in Armed Conflict." http://www.unicef.org/sowc06/pdfs/option protocol_conflict.pdf. . 2007. "From Words to Action Final Conference Report.". http://www.unicef.org/emerg/files/icwac report.pdf. Accessed February 4, 2016. . "The Convention on the Right of the Child: Guiding Principles: General Requirement for All Rights." http://www.unicef.org/crc/files/Guiding Principles.pdf.

United Nations of Human Rights-Office of the High Commissioner. 2000. "Optional Protocol to the Convention on the Rights of the Child on the Involvement of Children in Armed Conflict." . "Convention on the Rights of the Child." http://www.ohchr.org/EN/ProfessionalInterest/Pages/CRC.aspx. Accessed May 2017.

UNSC. 2000. "Annex to the Letter Dated 9 August 2000 from the Permanent Representative of Sierra Leone to the United Nations Addressed to the President of the Security Council." News release, June 12, 2000. http://www.rscsl.org/Documents/Establishment/S-2000-786.pdf. .2000. "Resolution 1315 Adopted by the Security Council at Its 4186th Meeting, on 14 August 2000." UN Security Council. August 14, 2000. http://daccess-ddsny.un.org/doc/UNDOC/GEN/N00/605/32/PDF/N0060532.pdf?OpenElement. . 2000. "Report of the Secretary-General on the Establishment of a Special Court 
for Sierra Leone.". October 4. http://daccess-ddsny.un.org/doc/UNDOC/GEN/N00/661/77/PDF/N0066177.pdf?OpenElement.

. "Letter Dated 22 December 2000 from the President of the Security Council Addressed to the Secretary-General." December 22, 2000. http://daccess-ddsny.un.org/doc/UNDOC/GEN/N00/812/77/PDF/N0081277.pdf?OpenElement. . 2001. "Letter Dated 12 January 2001 from the Secretary-General Addressed to the President of the Security Council." January 12, 2001. http://daccess-ddsny.un.org/doc/UNDOC/GEN/N01/211/71/PDF/N0121171.pdf?OpenElement. .2001. "Letter Dated 31 January 2001 from the President of the Security Council Addressed to the Secretary-General." January 31, 2001. http://daccess-ddsny.un.org/doc/UNDOC/GEN/N01/234/97/PDF/N0123497.pdf?OpenElement . 2001. "Letter Dated 23 July 2001 from the President of the Security Council to the Secretary-General." UN Security Council. July 23, 2001. http://daccessddsny.un.org/doc/UNDOC/GEN/N01/465/28/PDF/N0146528.pdf?OpenElement. . 2001. "Letter Dated 26 December 2001 from the Secretary-General to the President of the Security Council." December 28, 2001. http://daccess-ddsny.un.org/doc/UNDOC/GEN/N01/718/52/PDF/N0171852.pdf?OpenElement. . 2003. "Report of the Special Representative of the Secretary-General for Children and Armed Conflict to the Security Council." UN General Assembly Official Document. November 10. http://www.un.org/en/ga/search/view doc.asp?symbol=S/2003/1053. . 2004. "Letter Dated 26 February 2004 from the Secretary-General Addressed to the President of the Security Council." March 10, 2004. http://daccess-ddsny.un.org/doc/UNDOC/GEN/N04/265/77/PDF/N0426577.pdf?OpenElement.

Vaha, Milla, and Leena Vastapuu. 2016. "Rafting Muddy Waters: Girl Soldiers and Complex Moral Agencies." Paper prepared for International Studies Association Annual Convention, Atlanta, March 16-19.

Vandewiele, Tiny. 2006. A Commentary on the United Nations Convention on the Rights of the Child Optional Protocol: The Involvement of Children in Armed Conflicts. Leiden: Martinus Nijhoff Publishers.

Vinopal, Kelly. 2015. "Researching Public International Law." American Society of International Law: 2-33. https://www.asil.org/sites/default/files/ERG_PUBLIC_INT.pdf.

Vyver, Johan. 2004."The International Criminal Court and the Concept of Mens Rea in International Criminal Law." University of Miami International \& Comparative Law Review 12: 57-149.

http://papers.ssrn.com/sol3/papers.cfm?abstract_id=1940084. 
Wagner, Markus. 2013. "Non-State Actors.” Max Planck Encyclopedia of Public International Law. http://opil.ouplaw.com/view/10.1093/law:epil/9780199231690/law9780199231690-e1445?rskey=4TDkKG\&result=1\&prd=EPIL.

Walter, Christian. 2007. "Subjects of International Law." Max Planck Encyclopedia of Public International Law. http://opil.ouplaw.com/view/10.1093/law:epil/9780199231690/law9780199231690-e1476?rskey=GrMcLz\&result=1\&prd=EPIL.

Waschefort, Gus. 2010. "Justice for Child Soldiers? The RUF Trial of the Special Court for Sierra Leone.” International Humanitarian Legal Studies 1: 184-204. . 2014. International Law and Child Soldiers (Studies in International Law). Hart Publishing Limited.

Werle, Gerhard. 2005. "Grounds for Excluding Criminal Responsibility." In Principles of International Criminal Law: 138-47.

Williams, Sarah. 2014. "Hybrid International Criminal Tribunals." Oxford Bibliographies. Working Paper N.3. http://www.oxfordbibliographies.com/view/document/obo-9780199796953/obo9780199796953-0069.xml.

Zgonec-Rožej, Miša. 2010. International Criminal Law Manual. London: International Bar Association's Human Rights Institute (IBAHRI). 


\section{ANA PAULA VON BOCHKOR PODCAMENI}

2013

2009

2007

2006

2003

2003

$2012-2017$

M.A. in International Relations at Florida International University in Miami, Florida.

Doctorate Fulbright Scholarship

M.A. in International Relations in International Relations at Institute of International Relations (IRI) at Pontifical Catholic University in Rio de Janeiro.

Visiting faculty at Brown University, Exchange program with Pontifical Catholic University in Rio de Janeiro.

B.A. in Social Sciences at Pontifical Catholic University in Rio de Janeiro.

Lato sensu course in International Relations at Institute of International Relations (IRI) at PUC- Rio.

Teaching Assistant at Florida International University in Miami, Florida.

\section{$\underline{\text { Conference Presentations }}$}

2017

Junior Symposium presentation: The Special Court for Sierra Leone's contribution to an emerging rule favoring children's criminal responsibility in International Criminal Law, ISA annual meeting, Baltimore, MD (February). (November). 